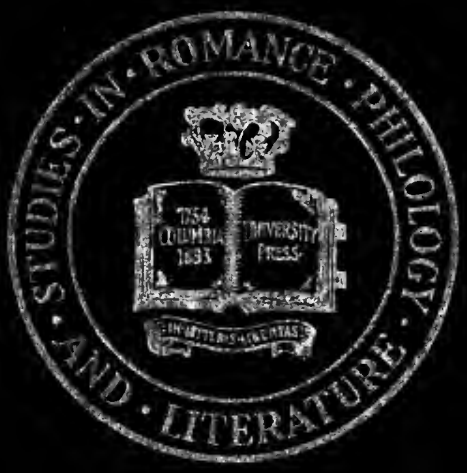

alifornia ional ility 
Digitized by the Internet Archive in 2007 with funding from Microsoft Corporation 


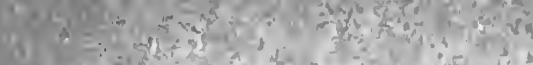

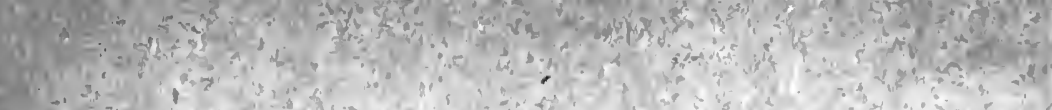
$-3,1$,

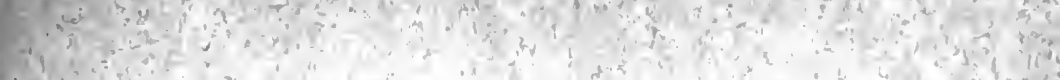

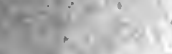
itis

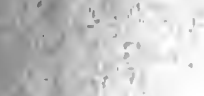

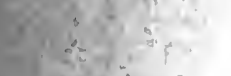

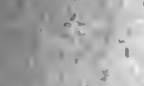
$+1, x^{3}$

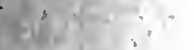
(3) $+1$ - 4

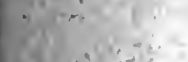

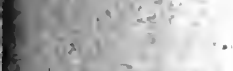

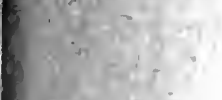
(1. +2 



\section{Columbia đanibetrite}

STUDIES IN ROMANCE PHILOLOGY AND

LITERATURE

\section{THE \\ EXTRAORDINARY VOYAGE \\ IN FRENCH LITERATURE}

BEFORE 1700 


\section{COLUMBIA UNIVERSITY PRESS SALES AGENTS NEW YORK LEMCKE \& BUECHNER 30-32 EAst 20Ta StreET LoNDON HUMPHREY MILFORD Amen Corner, E.C. ShanghaI \\ EDWARD EVANS \& SONS, LTD. 30 North Srechuen ROAD}




\title{
THE \\ EXTRAORDINARY VOYAGE \\ IN FRENCH LITERATURE

\author{
BEFORE 1700
}

\author{
BY \\ GEOFFroY ATKINSON, Ph.D.
}

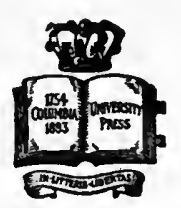

\section{伊em 望ork}

COLUMBIA UNIVERSITY PRESS

1920

All rights reserved 
Copyright, 1920

By Columbia Univeratty Press

Printed from type, 1920 


\section{PREFACE}

Tris study was begun in October 1916 at the suggestion of Professor Gustave Lanson, who was at that time lecturing at Columbia University, and to whom it was my privilege to act as office assistant. My research has been twice interrupted: from January to March 1917, while I was in France as Secretary and Interpreter to the Rockefeller Tuberculosis Commission, and again from May 1917, when I went to France as a private soldier of the United States Army, until January 1919, at which time I returned to the United States and to civilian life.

Although I had originally intended to make a complete study of the history of the Extraordinary Voyage as a type of novel in French Literature, I have been obliged, - by the extent of the subject, to limit my study in the present volume to the period preceding the year 1700 . It is my purpose to continue in a second volume the investigation of the Extraordinary Voyages published since that date.

It is only fitting to say that without the suggestion of Professor Lanson the present work never would have been begun, and that, without his continued interest, it certainly never would have been completed. If in its accomplishment any credit whatever is to be accorded, this will have been due in large measure to the inspiration received from Professor Lanson. If on the other hand, errors of statement or of judgment are discovered in it, they may be set down as exclusively my own. 
Two other French scholars, Visiting Lecturers at Columbia University, have been kind enough to take an interest in my investigations. To Professor Fernand Baldensperger, now of the University of Strasbourg, I am indebted for aid in the bibliography of the subject, while to Professor Anatole Le Braz, of the University of Rennes, I am grateful for much helpful criticism and suggestion during the last months of my work on this subject.

Furthermore, to Professors Raymond Weeks and A. G. H. Spiers of Columbia University and to Professor H. Carrington Lancaster of Johns Hopkins University I am under many obligations. Through their sympathy for French scholarship and French ideals, these men have supplemented the inspiration it has been my privilege to receive from the visiting lecturers above named.

For advice and assistance in preparing this study for publication, I am much indebted to Professor H. A. Todd of Columbia University. 


\section{CONTENTS}

PAGE

Preface........................

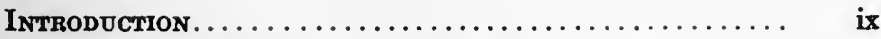

Chapter I. Descriptions of Real Voyages........ 1

II. Imaginart Realms Before $1675 \ldots \ldots \ldots, 12$

III. Precursors of THE Extraordinary Voyage. 25

IV. La Terre Australe connue of GABRIEL FoIGNY, 36

V. L'Histoire des Sévarambes of Denis Vairasse D'Alats................... 87

VI. A Political Satire and Two Translations 140

VII. Les Aventures de Télémaque of Fenelon... 144

Conclusions............................ 162

APPENDIX $\ldots \ldots \ldots \ldots \ldots \ldots \ldots \ldots \ldots \ldots \ldots \ldots \ldots \ldots \ldots$

Bibliography. ......................... 175

INDEX . . . . . . . . . . . . . . . . . . . . . . . . . 187 



\section{INTRODUCTION}

\section{Definition}

The term Extraordinary Voyage is used in the present study to designate a novel of the following type: A fictitious narrative purporting to be the veritable account of a real voyage made by one or more Europeans to an existent but little known country - or to several such countries - together with a description of the happy condition of society there found, and a supplementary account of the travelers' return to Europe.

By the terms of this definition the Extraordinary Voyage is an imaginary one. But even within the restrictions of a limited literary period, it would be futile to attempt to cover intensively so broad and varied a field as that of Imaginary Voyages in general. It is necessary to exclude from consideration accounts of travel by land only, of travel in familiar European countries, of voyages to other planets, of voyages made in dreams, by witchcraft, by charms, or other supernatural means. As the Extraordinary Voyage is an imaginary one - a novel - the term will not include accounts of voyages actually made, although these accounts may contain many or all of the characteristics of the $E x$ traordinary Voyage barring that of a voyage made in the imagination rather than in reality.

The term Extraordinary Voyage is then merely a label, convenient for purposes of classification. It implies, not of itself, but because it has been so defined here, the 
limitations which have been arbitrarily assigned to it. It is perhaps unfortunate that the terminology of literary history does not furnish a word which would imply the limitations above defined. The fact remains that there is no fitting term at present in use, so that limitation by definition becomes necessary. The reason for choosing the word "extraordinary" rather than any other is that the title Voyages extraordinaires has already been applied to this category by M. Gustave Lanson in designating the group of novels whose treatment is undertaken here. ${ }^{1}$

The main distinction between the Extraordinary Voyage as a type, and (for example) the Utopia of More or the Voyages of Cyrano de Bergerac, lies in the realistic treatment of the Extraordinary Voyage. The same distinction is found between the Extraordinary Voyage and the political satire of anagram names, or between the Extraordinary Voyage and the affected voyages in the lands of Love so common in the 17th century in France. It is precisely by the authenticated realism of their setting that the Extraordinary Voyages carried weight as works of religious, social, or political criticism.

\section{Purpose of the Present Study}

It is intended in this study to treat the Extraordinary Voyages before 1700 both as individual productions and as a group of novels. The first attempts in the direction of this type of novel will be studied in the early part of the 17 th century. In addition to considering the philosophical and utopian content of each, the three complete novels of the type published before 1700 will be treated as novels, and the sources of realism in each will be traced to accounts of real voyages of earlier date.

1 G. Lanson, Manuel bibliographique de la littérature française moderne. Paris, 1914. 


\section{The Place of the Extraordinary Voyage in THE 17Th Century}

M. Lanson has considered the Extraordinary Voyage as a manifestation of the rationalistic spirit in the 17 th and early 18th centuries of French Literature. ${ }^{2}$ The philosophic novel is one of many forms of literature made use of by M. Lanson in order to trace the development of rationalistic thinking in France. These novels are adduced by him as proof that the "esprit philosophique" of the 18th Century was not the consequence of reasoning a priori, but rather the result of new and concrete examples brought to the attention of men trained in rationalistic thought. It would be vain to comment on, or to attempt to resume here a study of the scope of this work of M. Lanson. What is of importance with regard to the present study is, that $M$. Lanson has treated the Extraordinary Voyage as a manifestation of a particular school of thought rather than as a type of novel. ${ }^{3}$

The first to call attention to this group of novels was M. André Lichtenberger, in Le Socialisme au xviii, siecle. ${ }^{4}$ His interest, as would appear from the title of his work, is largely connected with the theory of property in novels of this type.

M. Gilbert Chinard, now of the Johns Hopkins University, in a study of very wide scope ${ }^{5}$ has considered the same type of novel as an example of the exotic influences in France during the 17th and 18th centuries. ${ }^{6}$

${ }^{2}$ Origines et premières manifestations de l'esprit philosophique, etc. Revue des Cours et Conférences, Dec., 1907 et seq.

${ }^{3}$ See also: G. Lanson, Le rôle de l'expérience dans la formation de la philosophie du xviii ${ }^{e}$ siècle en France. Revue du Mois, t. ix (1910).

4 Paris, 1894.

- L'Amérique et le rêve exotique dans la littérature franģaise au xvii et au xviii ${ }^{e}$ siècie. Paris, 1913.

pp. 188-220. 
To M. Chinard the chief interest of these novels is, of course, the fact of their "exotic" nature, although he points out the philosophic content of each on the basis of M. Lanson's previous work, which is referred to by him and at least in one instance quoted.

It has often been said that the ideas developed by great authors are theirs only in the sense that through their genius of expression these authors have given them lasting form. The precursors of these great formulations are forgotten with a rapidity which is surprising, even though it may be just.

Until the recent studies of the three scholars just cited, the men whose writings are to be considered here were, with one exception, forgotten and unknown. Works of imagination, based on rationalistic processes of thought and involving criticism of existing conditions, had heretofore seemed to the average scholar to belong almost of necessity to the 18th century of French Literature. In the 17th century, the imaginative work of Cyrano de Bergerac, and the popularized science of Fontenelle appeared, as it were, rather lost and out of place. With the work of scholars since the appearance of Lichtenberger's Le Socialisme au xviii ${ }^{i}$ siècle has come the realization that the "philosophic" spirit, generally associated with the 18th century of French Literature, has its roots in the years before 1700, and that Télémaque (1699) is not a sporadic manifestation without predecessors.

The present study is concerned chiefly with the development of one generic form, and with the particular analysis of three specific novels, of the type:

La Terre australe connue of Gabriel Foigny, 1676;

L'Histoire des Sévarambes of Denis Vairasse d'Alais, 1677-79;

Les Aventures de Télémaque of Fénelon, 1699. 
It is not contended that the works of Foigny, Vairasse, and their equally obscure predecessors are of an importance approaching that of the works of Fénelon, De Foe, Rousseau, Voltaire, Chateaubriand, and other famous writers of later centuries. Were it not for these men of greater genius in later years, the work of investigation contemplated here would be without justification. It is easy to believe, however, that these precursors of the great figures are worthy of study, and that they are perhaps more worthy of study than are those mediocre spirits of the 18th century who basked in the reflected glory of contemporary genius.

Because of their resemblances and contrasts to the great writers of their time, such minor authors as Tiphaigne de la Roche, Guillard de Beaurieu, the abbé Dulaurens, Simon-Nicolas-Henri Linguet, Rétif de la Bretonne, and many others, ${ }^{7}$ have been taken from their quiet shelves, dusted, and found to present a certain interest. Perhaps less apology is required for studying here those rationalistic writers of imaginative voyages who drew for their realistic setting on published accounts of actual voyages of the 17 th century and on accounts of ancient civilizations, and who placed in this setting imaginary and uncorrupted peoples for the purpose of preaching criticism of the France now generally studied in Racine, Bossuet, and Mme. de la Fayette.

${ }^{7}$ A. Lichtenberger, Le Socialisme utopique, Paris, 1898. 



\title{
THE EXTRAORDINARY VOYAGE \\ IN FRENCH LITERATURE
}

\author{
CHAPTER I \\ DESCRIPTIONS OF REAL VOYAGES \\ 1. Illustrated Cosmographies. \\ 2. Realism in some accounts of Voyages after 1600 . \\ 3. Interest in Accounts of Voyages.
}

\section{Illustrated Cosmographies}

Widespread interest in geography in the Middle Ages is evidenced by "cosmographies" of the type of the Image du Monde. These fantastic cosmographies, such as that of Maitre Gossouin, ${ }^{1}$ were followed, in the closing years of the 16th century, by a cosmography in the modern sense of the word. In this, and in subsequent collections of accounts of voyages in the 17 th century, it is possible to trace a growing interest on the part of the public in descriptions of far-off lands, and an increasing amount of realism in the accounts of voyages published.

The cosmography of the father and sons De Bry was published from 1590 to 1635 . It is generally divided into the Long Voyages and the Short Voyages (Grands et Petits Voyages). One part deals with the history of the dis-

1 L'Image du monde de Mâ̂tre Gossouin, printed at Lausanne, 1913. (Bibliography under Gossouin.) This work of Gossouin is cited as a type. There is no reason for dealing here with the other cosmographies of the same period. 
covery of America, the other part with an account of the discovery of the East Indies. ${ }^{2}$ The father and two sons who published this voluminous collection were engravers by trade, and resorted to the history of discovery and exploration in five-continents as a means of utilizing and displaying their undoubted skill in the art of illustration. The many volumes, containing accounts of voyages, shipwrecks, explorations, descriptions of fauna and flora, tables of Latin and Indian languages, are fertile in maps. But their illustrations - hundreds of engravings of all sorts - are even more interesting. There are battles, and ceremonies of state; there are plants and flowers; there are beasts such as never were on land or sea: the seacow with horns, the unicorn, the two-headed monsters, the giant bird the Ruk, - these and many more superstitions, generally characterized as of the Middle Ages, survive into the 17th century in this cosmography. The juxtaposition of the text and the engravings gives these latter (which were to the engravers perhaps only the continuation of a tradition) a curiously life-like quality. ${ }^{3}$ If the printing of Marco Polo's travels in Latin ${ }^{4}$ and their later translation into other languages had stirred the imaginations of many readers during the 16th century, these illustrated accounts of exploration in Africa, Asia, Australasia, and the two Americas supplied an additional stimulus to the eye. All the strange and grotesque animals to the contrary notwithstanding, the minute description of costumes, idols, plants, and vermin of the De Bry collection must have

2 See Bibliography, De Bry.

3 For appreciation and table of contents of this collection see: A. G. Camus, Mémoire sur la Collection des Grands et Petits Voyages, etc. Paris, 1802. This work is of great use in searching for proper names occurring in the collection.

4 First Latin edition, Antwerp, circa 1485 (according to P. Martino, L'Orient dans la littérature, française, Paris, 1906, p. 12). 
brought a realism to the far places of the earth for the European reader.

\section{Realism in Some Accounts of Voyages AFTER 1600}

The realism of the engravings of the De Bry collection is a feature which becomes even more striking in accounts of voyages after 1600 . It is not intended in the short space of this chapter to treat extensively the realistic element in accounts of Voyages in the 17th century in France. Perhaps no better idea of the minute descriptions of commonplace objects in accounts of far lands can be obtained than that which comes from reading $\mathbf{M}$. Chinard's work on Du Tertre as a predecessor of Rousseau. ${ }^{5}$ It is intended here merely to point out some of the elements of realism in accounts of Voyages that have not been mentioned by M. Chinard.

First through the illustrations and the text of collections like that of De Bry, then through other accounts of voyages in later years, the far places of the earth came to be more than a hazy dream to the readers in 17th century France. By definite maps, even though these were grossly inaccurate, by meticulous descriptions of animals, birds, insects, plants, and fruits, the far lands became in some measure real to those who stayed at home.

At Douai in 1605 appeared a large quarto volume which continues the tradition of the earlier works of the engravers De Bry. This is the:

Histoire universelle des Indes Orientales et Occidentales, par Cornille Wytfiet et Ant.M. A DOUAY, aux despens de François Fabri, 1605.

There are two very complete maps of the Terre Australe (pp. 67 and 70) filiing the entire Antarctic region, ap-

' L'Amérique et le rêre exotique, pp. 39-52. 
proaching the Cape of Good Hope, including the Tierra del Fuego and thereby approaching the mainland of South America. In the neighborhood of Java, this tremendous Antarctic land appears further north than the tropic of Capricorn. One of these maps is circular, with the South Pole at the center. The text of this book is, however, impersonal and uninteresting.

Another and a better known book of travel is that of Jean Mocquet, Garde du Cabinet des singularitez du Roy. These voyages appeared at Paris in 1616, and 1617, at Rouen in 1645, in 1665 and in many translations, among them the fairly common 1696 edition at London. The title of the 1617 edition is:

Voyages en Afrique, Asie, Indes Orientales \& Occidentales faits par Jean Mocquet, Garde du Cabinet des Singularitez du Roy, aux Tuileries. Paris, chez Jean de la Heuqueville, MDCXVII.

M. Chinard ${ }^{6}$ has called attention at length to the strong exotic flavor of this rare story of adventure, and to the interest of Mocquet in plants, flowers and animals. M. Henri Jouan has also made a charming sketch of the man Mocquet as reflected in his writings. ${ }^{7}$ Aside from the author's convincing style, and his descriptions of ships, pirates, strange peoples, hunger, thirst and misfortune, there are other interesting elements in the book. After the first part, there are illustrations of camels with cloven hoofs, like those of cows, and with tails like those of horses. At the end of Livre 2 are eight startling illustrations (in the same manner though not so well executed as those of De Bry) depicting cannibalism, Brazilian native dances and warfare. Arms and legs of victims are seen roasting over a fire, while the natives sit in the

- G. Chinard, L'Amérique et le rêve exotique, pp. 24-29.

- Mémoires de la Société Nationale Académique de Cherbourg, 1904. pp. 1-29. 
foreground, gnawing on human limbs. In Livre 3 there are descriptions of Christian martyrs, and a striking account of a dog protected by a lion from other lions (p. 187). This real interest in animals, apparent throughout the book, is strikingly modern. Another, and perhaps a still more noteworthy trait, is Mocquet's appreciation of inanimate nature. In Livre 4 the author's departure from a port in Brittany is sketched in with one stroke of the brush: Ce fut vn matin \& par vne grande tourmente (p. 214). The minute realistic descriptions of the manners and customs of strange peoples in Mocquet's Voyages has been mentioned by M. Chinard.

Engravings of fruits, trees, vegetables, pottery as well as maps, are found in many collections of voyages in the 17 th century before 1675 . Perhaps as abundant as any collection in these illustrations is the Recueil de Voyages of Justel:

Recueil de divers Voyages faits en Afrique et en l'Amérique qui n'ont point esté encore publiez. Paris, chez Loü̈s Billaine, MDCLXXIV.

It is curious to note in this book a long discussion on the unicorn (pp. 220-223), under the title De la fameuse Licorne, des lieux oil elle est nourrie \& comme elle est formée. Side by side with it are minute descriptions of plants and vegetables common in the West Indies, Africa and elsewhere.

Typical in a way of books of travel in the early 17 th century in France is an account of a voyage to the East Indies, which appeared in a small $12 \mathrm{mo}$ volume at Paris in $1645 .^{8}$ The Privilège $d u R o i$ is of February 5th, 1645. Although the title does not give the name of

8 Relation d'un voyage aux Indes-Orientales par un Gentil-homme François arrivé depuis trois ans, avec une hydrographie pour l'intelligence dudit voyage, Paris, Chez Pierre Villery et Jean Guignart, au Palais, MDCXLV, avec privilège. 
the author, the privilège reads in part, "Il est permis a C. D. B. S. D. L. G. d'imprimer, ou faire imprimer."

Two things make this small volume, not mentioned previously to my knowledge, worthy of notice: its realism, and interest in the exotic. The author takes an interest in religious matters when they are exotic, for one reads (p. 3) of a negro prince, Ce Prince se disoit Chrestien, $\&$ nous monstra vne Chapelle \& vn Crucifix . . . pour marque de sa pieté ... Ils vont nuds, \& ont plusieurs femmes, quoy que Chrestiens."

Realism with regard to savages is found in descriptions of the natives at the Cape of Good Hope. The women are laides \& ont si peu de nez, qu'elles sont fort comme des singesses \& tous ces sauuages puans comme des boucs, viuans sans Dieu, sans Roy \& sans Loy . . . (p. 5).

The island of Formosa is called la belle des belles (p. 46), and eulogized. There is a prince (p. 70) who a pris le Christianisme en telle hayne, qu'il a fait mourir iusques $a$ des Princes de son sang. Different races of different religions living together cause some comment (p. 81): Comme toute sorte de peuples trafiquent en cette ville il y a aussi de toutes sortes de Religions, fors la Chrestienne, \& toutefois ceux mesme qui adorent on seul Dieu, n'ont aucune regle. Here is religious freedom.

Mention is made (p. 82) of plusieurs sortes de Mahometans, quelques vns ont des Chapelets \& d'autres font le signe de la Croix.

Most of the book is filled with accounts of guard-duty, insurrection of natives, battles between the Dutch and the Portuguese, reports of gold, silver, spices, and stories of piracy. There is realism in this also. We find, for instance (p. 23), one very distinguished Chinese admiral and pirate reduced to peddling beer for a living in Formosa.

Minute and careful description of fear-inspiring events 
is found in accounts of the earthquake in Canada in 1663, as described by Jérome Lallemant in his:

Relation de ce qui s'est passé de plus remarquable aux Missions des Pères de la Compagnie de Jesus en la Nouvelle France ès années $1662 \& 1663$. Paris, chez Cramoisy, 1664.

\section{Interest in Accounts of Voyages}

These Jesuit reports on Canada were published by Cramoisy at Paris, almost yearly, for a considerable period. For instance:

Relation de ce qui s'est passé en la Nouvelle France en l'année 1639 (Paul LeJeune), Paris, 1640;

ès années $1640 \& 1641$ (Barthélémy Vimont) Paris, 1642;

en l'année 1642 (Barthélémy Vimont) Paris, 1643;

ès années $1643 \& 1644$ (B. Vimont) Paris, 1645 ;

ès années 1644 \& 1645 (B. Vimont) Paris, 1646;

ès années 1645-1646 (Jérôme Lallemant) Paris, 1647.

In the years 1650 to 1663 these relations were written by Paul Ragueneau; in 1654 and 1655, by François Le Mercier. The two publishers, Sebastien and Gabriel Cramoisy, also published many other relations such as:

Relation de l'establissement des François depuis l'an 1635 en l'isle de la Martinique, etc. (Jacques Bouton), Paris, 1640.

Relation des Missions des PP de la Compagnie de Jésus dans les isles \& dans la terre ferme de l'Amerique meridionale. Paris, 1655 (by Pierre Pelleprat).

Neither was publication of missionary and colonial reports limited to Paris. After 1650, a great publication of such accounts seems to begin, and throughout France. The Relation de l'establissement d'une colonie françoise dans la Gardeloupe ${ }^{9}$ etc. of Mathias Dupuis,

$\rightarrow$ Guadeloupe. 
Caen 1652, has not been mentioned previously to my knowledge.

In the first ten years of the century a great part of the published voyages were translations such as G. $M$. Lodewijcks'

Premier livre de la navigation aux Indes Orientales par les Hollandois, etc. Amsterdam, 1609,

or Diego Bollo de Torres'

La nouvelle histoire du Perou par la relation du Pere Diego de Torres. Paris, 1604.

The better known Histoire naturelle et morale des Indes, of Acosta, was repeatedly published in translations from the Spanish at the beginning of the century. This publication of translations does not cease later, when many accounts of voyages were being published by Frenchmen. L'Histoire du nouveau monde ou Description des Indes Occidentales, of Joannes de Laet, Leyden, 1640, was followed by other translations from the Dutch.

Accounts of travels by Frenchmen, such as the Description du premier voyage faict aux Indes Orientales par les Français en l'an 1603, of François Martin de Vitré, Paris, 1604, necessarily rare at the beginning of the century, multiply rapidly toward 1650 . The Voyages fameux du sieur Vincent Le Blanc (1648) will be examined at length in Chapter III. A less interesting traveler but one far better informed is François de Gouz, sieur de la Boullaye. In his curious book, this traveler shows knowledge of the voyages of Magellan, Drake, Mocquet, and Vincent Le Blanc, among others. For one interested in the extent of publication of accounts of voyages at the time, it is interesting to consult the four unnumbered pages (viz. four pages of criticism of then existing books of travel) following the $A u$ lecteur of: 
Les voyages et observations du Sieur de la Boullaye-le-Gouz en ... Italie, Grece, Syrie, Palestine, ... Indes Orientales ... Arabie ... Egypte... Irelande ... Pologne etc. Paris, G. Clousier, 1658.

The acheve d'imprimer of this curious work is of the 8th May, 1653. Here is nothing flamboyant, nothing grossly exaggerated. François de Gouz, Gentilhomme Angevin, is a worldly, cautious sort of traveler, of the general type of the better known travelers who follow in the late 17th Century, such as Tavernier or Bernier. He pokes fun at the gullible Vincent Le Blanc (whose importance is greater than his own for the present study) in the following terms:

Vincent LeBlanc pourroit disputer avec Vlisse de la longueur de ses Voyages, il donne beaucoup d'instruction de l'Affrique aux Geographes modernes \& il seroit à desirer qu'il eust sçeu les Langues Orientales, afin de rapporter les noms propres des lieux où il a esté. (Pages following Au lecteur.)

Interest in the East Indies, and particular interest in China, is evident in the same period following 1650 . It is generally contended that the East held no appreciable interest for French readers until the last quarter of the 17th century. The publication of the following works would seem, perhaps, to modify this conclusion:

Claude B Morisot (editor), Relations veritables et curieuses de l'isle de Madagascar et du Bresil. Avec . . trois relations d'Egypte \& une du Royaume de Perse. Paris, 1651.

Marucci, Giovanni, Relation de ce qui s'est passé dans les Indes Orientales en ses trois provinces de Goa, de Malabar, du Japon, de la Chine \& d'autres païs (tr. from Italian), Paris, chez Cramoisy, 1651.

Rhodes, Alexandre de, Relation des progrez de la foy au royaume de la Cochinchine (edited by Jacques Machault). Paris, chez Cramoisy, 1652.

Sanson, Nicolas (d'Abbeville), L'Asie en plusieurs cartes 
nouvelles...en divers traittés de géographie et d'histoire. Paris, 1652.

Rhodes, Alexandre de, Divers voyages et missions en la Chine \& autres royaumes de l'Orient. Paris, chez Cramoisy, 1653.

Boym, Michel, Briefve relation de la notable conversion des personnes royales . . en la Chine. Paris, chez Cramoisy, 1654.

Martini, M. Histoire de la guerre des Tartares contre la Chine (tr. from the Latin), Douai, 1654.

In the light of this extensive publication of accounts of voyages, of missions, of foreign wars, other civilizations and religions, it is only natural to assume the existence of a very considerable interest in such accounts before 1660, in France. This interest has been referred to both by M. Martino (particularly after 1660) in L'Orient dans la littérature française au xvii et au xviii siècle, and by $M$. Chinard in dealing with America. With the exception of the works of François Martin de Vitré (1604), of Jean Mocquet (1616), and the translations of Acosta $(1598,1600$, etc.), none of the editions cited in this chapter have been referred to by either M. Martino or M. Chinard. ${ }^{10}$ It is therefore probable that this interest in far lands, in France before 1660, an interest whose study was initiated by these two scholars, was even greater than M. Martino or M. Chinard suspected. There is still much to be done before a complete bibliography of published voyages in the 17th century in France will be available, and it is the purpose of the present writer. to contribute to the still incomplete list rather than to criticize in any way the greater work of the pioneers in this field.

10 M. Chinard (op. cit. p. 122) does cite the collected Jesuit Relations. The original Relations published by Cramoisy almost at the rate of one small volume a year during the period 1645-1660 are perhaps even more impressive than the collection of 73 volumes (1610-1791) cited by M. Chinard. 
There is record in 1663, of this interest in published accounts of voyages. It is found in the letters of Chapelain. In a letter dated December 15th, 1663, and addressed to Carrel de Sainte-Garde, ${ }^{11}$ Chapelain says:

Nostre nation a changé de goust pour les lectures et, au lieu des romans qui sont tombés avec la Calprenède, les voyages sont venus en crédit et tiennent le haut bout dans la cour et dans la ville.

That this was not a passing fancy in taste is witnessed by the continued publication of voyages after this date, and in ever increasing volume. It is upon this taste for voyages, that the writers of Extraordinary Voyages after 1675 depended, in part, for their reception by the public. It was thanks to the popularity of published voyages that the writers of novels with voyage settings gained the attention - and sometimes the credence - of their readers.

There is a didactic content in the Extraordinary Voyages, whose sources will be investigated in the next chapter. The authors of the Extraordinary Voyages were beset by a desire to preach, in somewhat the same way that Plato, More, Bacon, and Campanella had desired to preach.

It would have been not only a thankless but a hopeless task to graft upon the amorous, the adventurous, or the burlesque novel of the 17th century the account of an almost perfect state of society. Creators of ideal commonwealths after 1675 turned for their settings to accounts of real voyages whose popularity with the public was established.

${ }^{11}$ Chapelain, Lettres, ed. Tamizey de Larroque, Paris, 1883, vol. ii, pp. 340-341. 


\section{CHAPTER II}

IMAGINARY REALMS BEFORE 1675

1. Before $\mathbf{1 6 0 0 .}$

2. Les Hermaphrodites, 1605.

3. Two followers of More.

4. The legend of the Incas.

5. The Austral Land.

\section{Before 1600}

IF, as will be seen later, the authors of Extraordinary Voyages after 1675 turned to detailed accounts of real voyages for material wherewith to substantiate their novels, it is not so with earlier creators of imaginary realms. The careful documentation of events, of dates, of places that is evident in later works, is distinctly lacking in earlier accounts of imaginary states of society. The development of the realistic setting for the presentation of such ideal commonwealths is a gradual development.

The regions visited by Saint Catherine, for instance, or the fabled Island of Saint Brendan are described in a medieval haze of the preternatural. Even Charlemagne and his paladins are travelers of a marvelous, an almost mythical type. It is a far cry from these miraculous lands of the Middle Ages to the imaginary territories of later years, which may only be reached by the shipwreck of a carefully authenticated Dutch or Portuguese merchantman.

Two well-known works of imagination of the 16th century share with their predecessors this lack of cir- 
cumstantial detail: Thomas More's Utopia, and Rabelais' Pantagruel (in particular Livre V). No one was made to believe, by the introduction of circumstantial and convincing details, that More's delightful fantasy was the description of a veritable country. The Isle Sonnante and the Pays de Lanternois must probably have seemed fantastic creations to Rabelais' contemporaries, however they may be regarded by more recent investigators of the subject. In both the works just cited there is, to be sure, a reminiscence of recent discoveries beyond the seas, but this reminiscence is far from showing the detailed and carefully authenticated realism which is subsequently found.

\section{Les Hermaphrodites, 1605}

There appeared in 1605 a satire on the morals of the court of Henri III, which has the form of an imaginary voyage. This is Les Hermaphrodites of Thomas Artus. The first edition of this curious book is very rare. ${ }^{1}$ Copies do exist, however, both at the British $\mathrm{Mu}-$ seum $^{2}$ and at the Bibliothèque Nationale at Paris. ${ }^{3}$ The author of this satire, Thomas Artus, sieur d'Embry, wrote also some translations, besides epigrams and predictions in collaboration with other writers. Among these are:

L'histoire de la décadence de l'Empire grec, et establissement de celuy des Turcs...et des tableaux prophétiques predisans la ruine de la mesme monarchie, par Artus Thomas, Paris, 1620.

1 M. Chinard, in L'Amérique et le rêve exotique, p. 190, doubts the existence of copies of the first erition.

2 Listed under "Artus." Cat. no. 1079, b.2.

3 Listed under "Artus." Cat. no. Lb 34/806.

- By reason of the inversion of "Artus Thomas" for "Thomas Artus," a confusion has arisen, certain American catalogues listing these works under "Thomas" instead of under "Artus." 
(The same): Avec la continuation de la mesme histoire jusques d l'an 1612, par T. Artus. Paris, 1650.5

Les Images ou tableaux de platte peinture des deux Philostrates ... mis en françois par Blaise de Vigenère, avec des epigrammes de T.A., Paris, $1614 .^{\circ}$

Les Hermaphrodites and a Discours de Jacophile à Limne appeared in two parts, in a duodecimo volume, according to the British Museum Catalogue in 1605. Neither of two copies at the Bibliothèque Nationale at Paris has name of place or date of publication. The second known edition, however, ${ }^{7}$ gives the following information:

on a trouvé ... que cet ouvrage n'a paru qu'en 1605, qu'on le vendoit à un prix excessif, que le Roy Henri IV se le fit lire, \& quoy 'qu'il le trouvât libre \& trop hardi, il ne voulut pourtant pas qu'on recherchât l'Autheur nommé Artus Thomas. ( $A u$ lecteur, p. 2.)

The 1697 edition of Bayle's Dictionnaire, in a note to the Article Salmacis, mentions this book as an ingenious satire on the court of Henri III, but does not give the name of the author.

The interest of the Hermaphrodites of Thomas Artus for the present study lies in the fact that this satire of the France of the late 16th century, published at the beginning of the 17th century, attempts to present a realistic setting, based upon accounts of genuine voyages.

5 This history was originally written by the Greek scholar Chalcondylas (or Chalcocondylas) of the 15th century, and the French version, with additions of the 17 th century, is often listed under "Chalcondylas."

- Subsequent editions of $1615,1629,1630$, and 1637 would argue a considerable interest in this work.

7 Relation de l'isle des Hermaphrodites, etc. Chez les Heritiers de Herman Demen, Cologne, 1724. It is this more common edition, one copy of which exists at the Widener Library, Harvard University, that is cited in references. 
The ideal community of More's Utopia, and the foreign lands visited by Pantagruel, both show the influence of the accounts of discovery. With Thomas Artus, a similar reflection is found in the setting of a satire.

The Hermaphrodites begins with a discussion, among friends, of the new worlds discovered beyond the seas. As an expression of the adventurous spirit of the time, the following brief sentence may be quoted:

la plupart du monde ancien, mesprisant son antiquité, a mieux aymé chercher, au péril de mille vies, quelque nouvelle fortune, que de se contenter de l'ancienne \& vivre en repos \& tranquillite (p. 1).

One of the friends discussing these matters begins an account of his adventures. The story of these adventures forms the rest of the book. He and a companion start to return to Europe after a long residence aux terres nouvelles descouvertes... ayans trouvé un navire marchand qui estoit prest de faire voile, \& qui tiroit devers Lisbonne. ${ }^{8}$ There is nothing more definite than this by way of orientation. After a short voyage, storm and shipwreck occur, followed by the miraculous escape of the narrator. These events are without the details that enliven later Voyages of the Extraordinary type. There is, however, a similarity in the arrival, on a strange shore, of a shipwrecked European. In this story the omission of amplifying details of the shipwreck and subsequent landing detracts from the force of the satire which is to follow.

The adventurer and his two surviving comrades have just finished thanking Heaven for their remarkable deliverance, when

nous vismes que la terre sur laquelle nous marchions estoit toute flottante, \& qu'elle erroit vagabonde sur ce grand Ocean

8 The use of a merchant vessel traveling the well-known route from the Indies as a means of substantiating the story is noteworthy. 
sans aucune stabilité. Lors saisis de nouvelle frayeur nous ne sçavions quelle resolution prendre, trouvant le faict tant estrange, qu'à peine pouvions nous adjouster foy à nostre veuë (pp. 4-5).

The resemblance of this vaisseau terrestre ... par tout si fertile \& florissant (p. 5) to the island of St. Brendan, is apparent. It is to be noted however, that the vogue of the floating island, like that of the unicorn, was still fairly great after $1600 .^{9}$ There follows a description of the beautiful palace found by the adventurer. The architecture of the building and its grace are particularly astonishing:

Le Marbre, le Jaspe, le Porphire, l'or, \& la diversité des émaux estoit ce qu'il y avoit de moindre (p. 5).

With little delay begins the investigation of the inhabitants, their customs and manners. It is a virulent and transparent satire of the court of a French King. For over ninety pages of a duodecimo volume the vanity, over-dress, pettiness, effeminacy, and immorality of the King and his courtiers are discussed and expatiated upon. In all these pages there is no story. The adventurer witnessed the ceremonies, heard the arguments, and read the book of laws of this depraved community. This book of laws, which the adventurer gives in full, is in the form of a royal proclamation. It contains a detailed denial of religion, morality, honesty, common decency, taste, manners, and reason. Let a very limited quotation suffice to show the extent of this perversion of society by royal edict in the Isle des Hermaphrodites:

Permettons ce qu'on apelle perfidie, trahison, \& ingratitude, que nous tenons pour sagesse, bonne conduitte, \& gentillesse d'esprit (p. 68).

- See serious criticism of a book dealing with this subject in Journal des Sçavans, 2 aout, 1677. 
nous voulons qu'on face cas d'un mary en proportion de la multitude des cornes qu'il portera, ainsi que les chasseurs font des Cerfs (p. 42).

This proclamation of vice covers the whole range of human affairs. From hypocrisy to murder, rape and incest, there is no crime that is not permitted, nay promoted.

The hermaphroditism of these people consists in their lack of true manly virtues (no physiological hermaphroditism being mentioned). In the virile eyes of the author the attention of these people to fine raiment, cosmetics, and soft indulgence makes them less than men, and more like women. Along with a condemnation of dandies, fops, and courtiers, there is also a condemnation of sex perversions of which no extended exposition is necessary.

At the end of the book appear some verses Contre les Hermaphrodites, and a Discours du souverain bien de l'homme. These two "items" are bound to the rest of the story by a simple device. The adventurer who tells the story says that these were given him by a guide, and that he sat down and read them. He simply recounts what he has read. The story itself is ended abruptly by another inartistic expedient. The adventurer tires of talking, and promises to continue his account at some later time. Thus he very simply avoids the necessity for narrating the return of the travelers to Europe.

The Description de l'isle des hermaphrodites is not an Extraordinary Voyage. It is a destructive, satirical criticism of existing conditions, under a transparent cloak. Its interest for the present study lies in its feeble attempt at realism on the basis of current accounts of voyages, and in its being written in French, rather than in Latin. ${ }^{10}$

10 There are a number of other matters bound with this book in the 1724 edition, one copy of which is at the Widener Library at 


\section{Two Followers of More}

Francis Bacon's Nova Atlantis and Campanella's Civitas Solis both appeared early in the 17th century." Both are of the general type of the Utopia. It will be recalled that the travelers in Bacon's Atlantis set forth from Peru for China and Japan, and travel five months with fair but soft winds before reaching their happy destination. In Campanella's dialogue, it is only the first speech of the Genoese Sea Captain - the first four lines - that deals with the geographical setting, and this is hazy in the extreme. Doubtless "Taprobane" meant even less to French readers in 1635 than "five months' travel from Peru." And but for "Taprobane" the City of the Sun is not oriented.12 The natural science element of the Atlantis as well as the religious ideas of Campanella and those relating to "the preservation of the species" will be discussed in their relation to the work of Foigny, Vairasse, and Fénelon after 1675. It is intended here simply to note the lack of detail to substantiate the statements of Bacon's and Campanella's travelers. These philosophers are too intent upon theory; the welding of the spirit of adventure and travel with the spirit of protest against existing evils has not yet taken place. The didactic element is too pronounced in Bacon and Campanella to allow of much interest in the setting.

Harvard University. These would be of interest perhaps to students of intrigue and personal details concerning courtiers under Henri III, but have no bearing on the present study.

${ }^{11}$ Civitas Solis, published at Paris, 1637. Nova Atlantis, published in 1627 (French translations not until 18th Century).

12 "Taprobane," generally Ceylon, is used in some 17th Century accounts of voyages to mean Java and Sumatra. 


\section{The Legend of the Incas}

The numerous translations and editions of the story of the Incas in the 17th century in France are fairly well known. The first translation is of 1633:

le Commentaire royal ou l'Histoire des Yncas, rois du Peru, escritte en langue péruvienne "par l'Ynca Garcilasso de la Vega, natif de Cozco, et fidellement traduite sur sa version espagnole par I. Beaudoin.

Other editions of this translation in French before 1675 are of 1658 and 1672 .

The translations of Plato and of Plutarch had brought to France the legend of perfect government, but in a haze of departed glory. The story of the Incas, according to Garcilaso, was an account of a modern and almost perfect state. It was also in some measure the defense of regulation of the affairs of men by a wise and paternal government. In one sense, the idealized community of the Incas was a reproach against existing evils of government and social affairs in Europe. The truth of Garcilaso's statements has been much questioned in later times, but there is little doubt of their acceptance as being true, at the time of these translations into French. It must have been more forceful and convincing in many ways than the far-off and unsubstantiated account of the Utopia of More, or of the Nova Atlantis of Bacon. The authenticity of the account is based on the representation that the author was a descendant of the Incas as well as of one of the Spanish conquerors under Pizarro.

The History of the Incas is briefly the account of a succession of kings. The first Inca and his sister-wife - posed their will and their superior minds upon the ccivilized inhabitants whom they found in ancient Peru. Claiming to be descended from the Sun, these 
two took to themselves the direction of religion as well as of government. Their descendants were the rulers, and later became the oligarchy of the land. Each king and queen of this nation was directly descended from the first Inca and his sister-wife. The succeeding kings subjugated neighboring tribes, built aqueducts for irrigation, and organized the administration of the country. Each ten men had a supervisor responsible to a higher official who in turn was responsible to still another. At the summit of this pyramid was The Inca, the monarch and high priest of his people.

By the building of store-houses and by the hoarding of grain in abundant years for distribution in years of dearth, by the regulation of clothing, by the assignment of duties to all men within certain age limits, and by the requirement of a certain minimum of labor for the State on the part of each individual, the paternal form of government supplied the needs of each subject. The kindness and forethought of the kings is epitomized in the following sentence:

en un mot ils se conduisoient d'une telle manière envers tout le monde, qu'on pouvoit les apeller de bons pères de famille, ou de fidèles oeconomes, plutôt que des Rois. ${ }^{13}$

Quite as interesting as is this eulogy of the paternal form of government is the Deistic point of view of the initiated among the Incas. The common people worshiped the Sun, and the formal religion of the State was sun-worship. The general faith held also that the soul is immortal, and that the wicked are punished after death (Livre I, ch. vii). Among the kings themselves, who were also the priests and theologians, there is more than sun-worship. The Inca Roca (Livre IV, ch. xvii) is reported to have said that:

${ }^{13}$ Livre V, ch. xi. The edition cited is that of 1737 . 
toutes les fois qu'il considéroit la grandeur, la lumière \& la beauté du ciel, il en tiroit cette conséquence; qu'il falloit bien que le Pachacamac (c'est ainsi qu'on appelle Dieu) fût un Roi fort puissant, puisqu'il avoit une si belle demeure.

The Inca Huayna Capac (Livre IX, ch. $\mathrm{x}$ ) uses a peculiarly rationalistic argument to prove the existence of an invisible God (the Pachacamac):

ce Soleil, qui est notre Père, doit relever d'un autre Seigneur plus puissant que lui, \& par le commandement duquel il fait la course qu'on lui voit faire tous les jours, sans que jamais il s'arrête. Car si le Soleil notre Père étoit souverain Seigneur de toutes les choses d'ici-bas, il y a grande aparence qu'il se reposeroit quelquefois pour son plaisir, puisqu'il n'y a point de nécessité qui le pût contraindre à marcher toujours.

That a people without knowledge either of Europe or of an orthodox revelation should have not only an ideal form of government but a belief in the immortality of the soul and in the existence of an unseen God is the striking report of Garcilaso. That the translations of this work were numerous argues not only that it was. well known in France, but conversely that it was a book of great interest to the public. The insistence of Garcilaso upon manual labor and upon tilling the soil is as. striking as is his insistence upon the king's responsibility for the welfare of his people. With the publication of this book there came to French readers an account of an almost perfect state of society in a modern land a real land - known to exist. ${ }^{14}$

14 There is a desert island story (Vol. I, p. 17) in this book which is worthy of mention. Pedro Serrano is left on a desert island and subsists on turtle meat for a long time. Another castaway joins him, and the two subsist until rescued. The grotesque "realism" of the following description of the man Serrano when rescued is worthy of citation: la barbe . . . l'incommodoit dans le lit et l'empêchoit de dormir. This story of Serrano has been mentioned by F. Wackwitz, Entstehungsgeschichte von Defoe's Robinson Crusoe, Berlin, 1909. 


\section{The Austral Land}

The modern idea of an Austral Land or continent came first to Europe in the Voyages of Marco Polo, published in Latin about 1485 . In reading Marco Polo, one does not meet the idea of a great continent known, but of a great series of islands visited (Java, Sumatra, etc.), together with rumors of a great continent beyond. The voyage of Gonneville to the coast of South America, and his report of a Terre Australe is fairly well known..$^{15}$ This intrepid sailor, Captain Binot Paulmier de Gonneville, brought back from the Southern Hemisphere a native, named Essomérik, the son of a local king. The party was almost lost, through an attack by pirates, just before landing on their return to Europe. Descendants of Essomérik (who was married to a French lady after proper admission to her faith) are traced by De Brosses to the year 1725. One of these descendants of Essomerik, his grandson, was the author of a publication referring to the Austral Land, which is of interest in the present study:

Mémoires touchant l'établissement d'une mission chrestienne dans le troisième monde autrement appelé la Terre Australe, Méridionale, Antartique, et inconnuë. Dediez à Nostre S. Père le Pape Alexandre VII. Par un Ecclesiastique Originaire de cette mesme terre.

These mémoires were published by Gabriel Cramoisy at Paris in December 1663, without the knowledge of the author, the abbé Paulmier, chanoine de Lisieux. An arrangement was made later to the satisfaction of both the author and the publisher, the name of the author being placed on the title page in printing after January

${ }^{25}$ C. De Brosses, Histoire des Navigations aux terres australes, Paris, 1756, pp. 115-118, and M. D'Avezac, Relation authentique du voyage du Capitaine de Gonneville, Paris, 1869. 
1664. It would seem that there must have been some considerable interest at the time in this publication.

Besides Captain de Gonneville, who wrote his version of the voyage of 1503-1504 early in the 16th century, the voyage of Magellan (1519), of Saavedra (1528), and of Garcia de Loaisa (1525) had been published in Latin by De Bry and others. The fact that these later explorers visited Australasia rather than South America made little difference to the reading public in France in the 17 th century. Gonneville himself gave no definite information as to where he had been, and for the average reader of the 17th century in France the Tierra del Fuego and Australia were very much the same thing.

The detailed and substantiated account of the Portuguese Captain Fernando de Quir (or Queiros) of his voyage to Australia (1606) was widely known by 1630 , thanks to publication of this account both in De Bry's India Orientalis (Liber $\mathrm{X}$ ) and in French translation. ${ }^{16}$ Similarly, the voyage to Australia of Captain François Pelsart (1629) was known through the publications of Melchisedech Thévenot. ${ }^{17}$ The account of Pelsart is realistic and detailed, but not in any way utopian. On the contrary, de Quir had claimed many and varied blessings for his newly discovered land. Other accounts of voyages to Australasia, of less importance in the present study, but published in the 17th century before 1675 , are those of Willem Schouten (1615) of Jacques l'Hermite (1624), and of Abel Tasman (1642) which may be found either in Thévenot's collection ${ }^{17}$ or in the English Purchas' Pilgrimes or the Hackluyt Collection.

${ }^{16}$ Requeste présenté au Roy d'Espagne par le Capitaine Pierre Ferdinand de Quir, sur la descouverte de la cinquiesme partie du monde appelée terre Australe incogneue, etc., Paris, 1617.

${ }^{17}$ Relations de divers voyages curieux qui n'ont pas esté publiées, Paris, 1663-1672. Another edition appeared in 1696. 
With all of these accounts, there had grown up a sort of legend of the "Terre Australe inconnue," where almost every delight of climate and fertility of the soil might be found. Many French people, missionaries, adventurers, traders, younger sons, and vagabonds had already been to America (largely the Antilles and Canada, although some missionaries and a few explorers to Brazil). The American setting was ideal for works of the imagination with a primary interest in adventure and piracy. ${ }^{18}$ This same setting could hardly be used for an imaginary and uncorrupted people having a complete, materialistic civilization. That American Indians had no houses, no canals, practically no agriculture was common knowledge in France toward 1670. The ideal civilization of the Incas was generally known to have perished either before the invasion of Pizarro or at the time of this invasion. There remained, however, the "Terre Australe inconnue," a vague sort of legend similar in a way to the "Tahiti" legend of a later day. It is in this setting that the first two Extraordinary Voyages place their ideal peoples. Before discussing the complete novels of Extraordinary Voyage, however, it seems wise to consider a literary ancestor of this novel.

18 See Nouvelles de l'Amérique ou le Mercure Amériquain, Roven, 1678 (cited by M. Chinard as an example of interest in adventure, piracy, and abduction). This book consists of three hair-raising nouvelles, whose detailed attempts at realism are sometimes revolting and sometimes laughable. 


\section{CHAPTER III}

\section{PRECURSORS OF THE EXTRAORDINARY VOYAGE}

1. Vincent Le Blanc. Philosophic Travels, 1648.

(A literary ancestor of the Extraordinary Voyage.)

2. L'Île Imaginaire, 1658.

(A Satire with geographic setting.)

1. Vincent Le Blanc. Philosophic Travels, 1648

IN August 1648 there appeared in Paris a small quarto volume of travels, which, although not an Extraordinary Voyage as defined in this study, merits some extended consideration. Because of its great realism and decided though slight philosophic content, it may be considered as a direct ancestor of the Extraordinary Voyages which follow 1675 , just as the early Utopias may be considered direct ancestors of this type of novel because of their large philosophic element and an indisputable, though faint, realistic setting. The title of this curious book is:

Les Voyages Fameux Du Sieur Vincent Le Blanc, Marseillois, $(Q u ' i l$ a faits depuis l'aage de douze ans iusques à soixante, aux quatre parties du monde.) Redigez fidellement sur ses Memoires $\&$ Registres, par Pierre Bergeron, Parisien, à Paris, Chez Gervais Clovsier, MDCXLVIII, auec priuilege du Roy.

In the first edition of 1648, the Epistre is dedicated to Messire Eustache Picot, Conseiller, Aumosnier du Roy, . . . etc., and is signed Louys Coulon. There is also the Priuilege du Roy ... Donné à Paris, le 15 iour de Septembre, l'an de grace 164\%. The achevé d'imprimer does not appear in the first edition, but in the second edition 
of 1649, is found: Acheué d'imprimer pour la premiere fois le 18 iour d'Aoust 1648. Les exemplaires ont esté fournis.

M. Chinard mentions ${ }^{1}$ an edition of 1658 at Paris, and in addition translations in Dutch (Amsterdam, 1654) and in English (London, 1660). ${ }^{2}$ M. Chinard has treated this book as an example of exotic interest in the 17th century in France. That it was widely read would seem even more certain in the light of the editions in French of 1648 and 1649, followed in 1658 by the edition referred to by M. Chinard. ${ }^{3}$

The Voyages of Le Blanc are in all probability what they purport to be - the diary and mémoires of a man who traveled extensively, published with additions and revisions by a lawyer. Pierre Bergeron, an advocat au Parlement de Paris, seems to have been a man deeply interested in travels. In his Relation des voyages en Tartarie ... plus un Traicté des Tartares ... avec un abregé de l'Histoire des Sarasins, of $1634,{ }^{4}$ he shows familiarity with the work of Hackluyt, Purchas, Marco Polo, as well as with some then unpublished manuscripts relating to travels in the Near East. Among these unpublished manuscripts mentioned in 1634 by Bergeron, is that which appeared fourteen years later as the Voyages fameux du sieur Vincent Le Blanc. That Pierre Bergeron had the manuscript of Le Blanc's notes at hand in $\mathbf{1 6 3 4}$ is indicated by references to these notes in the Traicte des Tartares and in the Histoire des Sarasins of that year. ${ }^{\circ}$

1 G. Chinard, L'Amérique et le rêve exotique, p. 79.

2 op. cit. p. 437. Brunet cites the Voyages of Le Blanc as Paris, 1649, ou Troyes, 1658 in-4 (no. 19897).

3 The first edition has not been mentioned before to my knowledge. One copy of it may be found in the New York Public Library.

1 Paris, 826 pp. in-8.

- Traicté des Tartares, p. 105; Histoire des Sarasins, p. 13. Mention is made of Vincent Blanc Marseillois and of his voyage en Arabie non encor imprimé. 
In the Advis au Lecteur of the first edition of Les Voyages fameux du sieur Vincent Le Blanc, it is stated that Pierre Bergeron and feu Monsieur Perez Conseiller au Parlement de Provence knew Le Blanc when he was alive, and honored him after his death by publishing his mémoires. It is really of little importance whether this be true or not. In any event it seems rather unlikely that Pierre Bergeron foresaw in 1634 that he would be able to foist a fictitious "Vincent Le Blanc" on the reading public fourteen years later, and so took pains to mention him in the Traicté des Tartares. There are many matters in the quarto volume of Les Voyages fameux that were plainly inserted by the editor. The Troisième Partie, which deals with America and the Antilles is evidently copied from other relations. Certainly Bergeron, or some collaborator, had read the Histoire des Yncas before writing the part dealing with Peru. There is however a convincing realism of personal experience in the First and Second Parts of the book, dealing respectively with Asia and with Africa. Whether this personal and realistic element of the first part of the book is that which originally existed in the diary of one man, Vincent Le Blanc, or whether it is a composite of various such diaries, matters little after all.

In reading carefully the Première Partie and Seconde Partie of this book, one is constantly in the presence of two types of men - men of widely different viewpoints. It seems easy to believe that Vincent Le Blanc did live, did travel, and did leave record of his adventures. Certainly no one staying in Paris could have invented all the circumstantial details in the story. That the editor took these details from the notes of one or more travelers and added to them from his own wide reading of travels is also easy of belief. Upon these hypotheses there are throughout the Première Partie and the Seconde Partie two men involved. One is a frank adventurer, trader, 
and wanderer, a man interested in the strange, the exciting, the curious, and the supernatural. This is Vincent Le Blanc, trader and traveler. He readily believes what is told him, and frequently recounts what he has heard as if these matters were of first-hand knowledge. The things in which Le Blane believes are legion: snakes with wings, catching fish by use of witchcraft, dishes which will hold anything except poison, and which break when poison is poured into them. $\mathrm{He}$ is canny and resourceful with respect to money, bargains, passports, and the influence of petty officials. He hates vermin, Portuguese ships and Portuguese ship-captains. He delights in murders, hangings, public executions, and amorous incidents.

The second man whose presence is felt throughout the book is evidently a lawyer. There is an interest in legal matters which is quite foreign to what one would imagine to be the interest of a trader such as Le Blanc. In a story fairly bristling with anecdotes of hangings, abductions, and sudden death, there are very few anecdotes of law cases. There are, however, many references to laws and trials. This law interest has plainly been inserted, together with other matters, by Bergeron the editor.

M. Chinard ${ }^{6}$ has called attention to the story of young Le Blanc's early departure from the parental roof in Marseilles by stowing away on a vessel bound for the Levant, as well as to the account of his first shipwreck. The young adventurer is soon in the Holy Land, where he finds the manna from Heaven to his liking! ${ }^{7}$ After this early test of the reader's powers of belief, there follows a series of marvelous and very badly written in-

- L'Amérique et le rêve exotique, pp. 80-81.

7 Voyages de Le Blanc, p. 7. (It is the edition of 1648 that is cited.) 
cidents. A Christian disguises himself as a dervish, and waits six years for an opportunity to murder an old enemy. People steal in and out of harems. Le Blanc traverses Persia, Arabia, and a large part of India, Ceylon, Java, and Siam in the First Part of the book. Over two hundred and fifty pages (small quarto) dealing with his travels in Asia, are filled with incidents of piracy, shipwreck, murder, plague, poisoning, witchcraft, and with description of natural phenomena.

The Second Part deals with Africa, including Madagascar. Le Blanc goes from Zanzibar to Cairo, overland, giving glass beads and necklaces to the royalty he meets.

The Third Part, dealing with voyages in the Mediterranean and to the two Americas, is quite different from the preceding portion of the book. Except for one incident of being captured by the Spanish and held prisoner in North Africa, there is little to remind the reader of the first parts of the book. The trading element, ever present in the travels in Asia and Africa, is distinctly lacking. Quite evidently, this last part of the book is an adaptation, made by Bergeron or some collaborator, of impersonal accounts of voyages which they had at hand. That the man who made a story of Le Blanc's diary was familiar with other accounts of voyages is evident throughout the book. The gorgeous imagination and petty personal interests of Le Blanc are punctuated all along with marginal notes such as "Comme Marc Pole remarque de la Tartarie, livre 2, ch. 18," and similar interpolations. The real Le Blanc, interested in trading and in avoiding vermin, can scarcely have been a reader of other people's Voyages. One would imagine that he was rather too much occupied with making voyages of his own. The relation of the two men, Pierre Bergeron and Vincent Le Blanc, is however of secondary importance. Those who read the book at the time it appeared doubtless did 
so because it is a narrative of adventure. Even to-day it is a story worth reading, as a compendium of all the known forms of exaggeration and prevarication.

The interest of the book for the present study of the Extraordinary Voyage lies in the fact that it embodies all the characteristics of this type of novel, barring the "imaginary" element. That some such man as Vincent Le Blanc lived and left an account (even exaggerated) of his travels, places the book outside the category of novels of imaginary voyage. That Le Blanc exaggerates, not to say lies flamboyantly, does not alter the fact that this is the account of a real, and not of an imaginary voyage.

It will be found in the analyses in later chapters of this study, that the Extraordinary Voyage has two distinct parts. One is realistic, the other theoretical or "philosophic." That there is realism in Le Blanc, no one would deny. There are plenty of complaints of boils, vermin, and ill-smelling cisterns to convince the reader that the story is based upon actual experiences. That there is no philosophic element in this book has been contended by M. Chinard. ${ }^{8}$ The man Le Blanc may not have been philosophically inclined. But thanks to the collaboration of Pierre Bergeron, the book of his voyages does contain a considerable amount of comparison between the happy state of society in foreign lands and the miserable state of affairs in Europe. There are also many passages referring to religious liberty. A few quotations will suffice to indicate this polemic content.

${ }^{8}$ L'Amérique et le rêve exotique, p. 83 . Here occurs:

Chez Leblanc, il ne faut s'attendre à trouver aucune idce, aucune théorie; il est naiff et enfantin par sa crédulité comme par son amour du merveilleux. Seules, les premières pages de son récit, ... montrent à n'en pas douter que, contrairement à ce que l'on dit trop souvent, le goat de l'aventure, de la mer, et des Ales désertes n'a pas été apporté chez nous par le Robinson anglais. 
There is a Mohammedan ruler (p. 38) qui laisse viure les Chrestiens en liberté. Speaking of India, there is mention (p. 66) of the people called:

Gusarates, qui est la nation la plus iuste, raisonnable \& religieuse de tout l'Orient; car à la maniere des anciens Pytagoriens, ils ne mangent chose qui ait eu vie... Ils ne font mal à personne, $\&$ ne respandent pas mesme le sang de leurs ennemis.

This stands cheek by jowl with accounts of bloodshed over religious differences among Christians. Again:

les estrangers y viuent dans la mesme franchise \& liberté que ceux du païs, chacun en sa Religion (p. 70).

Chacun vit là en sa Religion auec toute liberté (p. 81).

Chacun y vit en asseurance, à cause de la bonne iustice qui $\mathbf{y}$ est renduë, \& les loix y son'́ si bien obseruées que personne ne les ose enfraindre crainte de punitiõ (p. 111).

Il y en a qui n'ont aucune Religion, \& toutesfois ils vont naturellement à l'immortalité de l'âme \& à quelque prouidence (pp. 151-152).

One reads of the Javans (p. 146) that they are cannibals, but:

cette canaille a coustume de dire que nous sommes de grands ignorans de laisser pourrir en terre vne si excellente chair qu'est celle de l'homme.

There is a curious account (p. 195) of a conflict between the authority of a local deity and that of a missionary from Europe. A petty King is cured of disease by a Christian missionary who mocks the local deity. Being cured, the King is loath to give up his old god qui leur auoit parlé si sounent \& fait tant de miracles entr'eux. His wife assures him, however, that if their god were strong enough to do any harm, he would strike this impudent Christian with lightning. It is not a far cry from this to the open questioning of revealed religions and miracles. 
In the Seconde Partie, treating of Madagascar (p. 11), occurs a direct comparison between this happy country and Europe:

Les habitans de cette isle ne songent qu'à viure ioyeusement, $\&$ ce qui est plus à admirer parmy vn si grand nombre de peuples l'on ne void aucuns vagabonds \& mendians comme en Europe. Ils se donnent tous du bon temps sans neantmoins faire tort à personne; les vns se contentent de peu, les autres veulent beaucoup, \& aucun ne manque d'occupation s'il veut trauailler. ... Ils viuent en grande amitié.

Another insertion, evidently from the hand of Bergeron, is found in the Seconde Partie, p. 34:

Ce qui est le plus remarquable en ces lieux-là, est qu'il n'y a aucune prison, à cause que toutes les affaires de Iustice se iugent sur le champ.

Later, speaking of sun-worshipers in Africa (p. 81), Le Blanc says:

Ils reconnoissent vn lieu où les mauuais sont tourmentez apres cette vie, les vns plus griefuement que les autres, à proportion de leurs pechez.

Of the court of Prince Negus (Seconde Partie) one reads: cette cour n'est point suiuie de tant de racaille de gens comme les nostres (p. 90).

Of the same people, it is stated:

estant chose inoüye entr'eux qu'aucun ait iamais conspiré contre son Prince... chose bien esloignce de la peruersité \& corruption des paīs de deça, \& particulierement de nostre malheureuse France, qui par vn ie ne sçay quel zele furieux, enragé $\&$ du tout diabolique, a trempé trop souuent sa main parricide dans le sang de ses Rois. Dieu luy fasse la grace d'imiter ces bons Abissins, meilleurs Chrestiens en cela qu'elle (p. 94).

Although far from being the only philosophic expressions in the book, these quotations will suffice to show 
that this curious narrative of adventure contains arguments for religious freedom, for the right to employment and for the right to prompt justice, as well as an open comparison of little known lands with Europe. The picture of men of many races and creeds living amicably in the free ports of the East Indies, is no less striking in its internationalism.

Thus the Voyages fameux du sieur Vincent Le Blanc, the result of the collaboration of two men, one a trader and adventurer, the other a lawyer and theorist, is a realistic story containing theories both political and economic. It reveals a distinct idealizing tendency, which gives it a utopian flavor. In the complete $E x$ traordinary Voyages of later date, the process of composition is, to be sure, different. But regardless of the processes of composition, and regardless of whether the later writers of Extraordinary Voyages knew this strange book (which went through three editions in ten years), the Voyages of Le Blanc must be considered a literary ancestor of the Terre australe connue of Foigny, of the Histoire des Sévarambes of Vairasse, and in a general sense, even of the Télémaque. ${ }^{9}$

- In the Premiere Partie of the Voyages fameux of Le Blanc. pp. 119-120, there are two interesting stories. One is that of a woman mating with a bear named Sagistan. The other is a desert island story. A woman, accused of adultery, is left on a desert island with her lover, by order of her husband. The lover dies. The woman is cared for by a monkey, becomes his mistress and has children by him. When she escapes on a passing vessel, the animal murders their offspring before her eyes. She returns to Europe, and lives a secluded life in a convent, after being acquitted by a religious court. The story is carefully substantiated. The same general type of story occurs in the Voyages of Mocquet (1617) previously referred to. According to Mocquet, an English pilot cast away in America, on the mainland, has a child by a savage woman, who murders this child before his eyes when he leaves on a passing vessel. (Mocquet, Voyages, Livre ii, pp. 148-150). It is not at all 


\section{L'île imaginaire, 1658}

In the Euvres de M. de Segrais ${ }^{10}$ occurs a nouvelle or a short satire, which, although not an Extraordinary Voyage, bears some resemblance to this type of novel. The story begins with adventures and shipwreck at sea; there is a description of the flora and fauna of the island, including bright blue and carmine colored rabbits. ${ }^{11}$ This much of the Île imaginaire is similar to the Extraordinary Voyages in being a reflection of the published accounts of real voyages and adventures, together with an extraordinary element of strangely colored animals. There follows the description of a republic of dogs on this island, which is a flippant satire on works of the type of the Utopia, the Nova Atlantis, and the Civitas Solis.

The great distinction between the Île imaginaire and the Extraordinary Voyages which follow, however, lies in the transparent insincerity of the former. The title itself, containing the word "imaginaire," counteracts whatever attempts at realism are found later. The reader takes up the story prepared to read a fiction. If he should happen to read the dedication a Madame de Pontac, he would come to the second confession of insincerity on the part of the author:

Je suis assûré qu'il n'y a Confesseur, même des plus séveres du tems, qui ne donne absolution d'un mensonge pareil à celui que je vous dédie.

unlikely that Bergeron knew the Voyages of Mocquet, and changed this story to suit himself. In the Voyages fameux of Le Blanc, this incident is given as a desert island story, which is not the case with Mocquet.

${ }_{10}$ Amsterdam, 1723 t. ii, p. 178; or Paris, 1755 , t. ii, p. 165 (about 40 pp. in-12).

11 A similar case of colored animals occurs in Foigny's Terre australe connue, 1676. See next chapter. 
Notwithstanding all the marvels of witchcraft, the apparent sincerity of the Voyages fameux of Le Blanc is strangely similar to the convincing realism of later philosophic voyages. On the contrary, the flippant and courtly fiction of Segrais is more nearly akin to the works of Gomberville or of Scudery than to those of Foigny, Vairasse, and others who follow. 


\section{CHAPTER IV}

\section{LA TERRE AUSTRALE CONNUE OF GABRIEL FOIGNY}

1. Life and Publications of Foigny.

2. The Adventures of Sadeur.

3. The Austral Land.

4. Conclusion.

\section{Life and Publications of Foigny}

IN 1676 there appeared the first novel which falls within the definition given of "Extraordinary Voyage." This is the Terre australe connue of Gabriel Foigny, as strange a story in many ways as any novel of the type. ${ }^{1}$

A second edition appeared in Paris in 1692, under the title Les avantures de Jacques Sadeur, ${ }^{2}$ an English translation at London the following year, ${ }^{3}$ two other editions at Paris (1693-1705), and an edition at Amsterdam in 1732.

The author, Gabriel Foigny, ${ }^{4}$ was a native of Lorraine. Born in 1640, he died in 1692 after a turbulent and far

${ }^{1}$ La Terre australe connue, c'est-a-dire la description de ce pays inconnu jusqu'ici, de ses mœurs \& de ses collumes, par Mr. Sadeur. Avec les avantures qui le conduisirent en ce Continent, \& les particularitez du sejour qu'il y fit durant trente-cinq ans \& plus, \& de son retour. Reduites \& mises en lumiere par les soins \& la conduite de G. de F. à Vannes, par Iaques Vernevil, ruë S. Gilles, 1676.

2 Chez Barbin, Paris, 1692. Although Sadeur is christened "Nicolas" in the first edition, the name occurs but once. His father's name is "Jacques," according to Sadeur's account of him. It is for this reason that later editions use the title Les avantures de Jacques Sadeur.

${ }^{3}$ A new discovery of terra incognita Australis by Mr. Sadeur, London, 1693. For titles of later editions see Bibliography.

- The particle "de" seems to have been assumed by Foigny the author. The man seems to have been known as Gabriel Foigny. 
from exemplary life. As a young man, he entered the order of Franciscan monks. Having left the monastery for reasons now unknown, he went to the neighborhood of Geneva and became a Protestant. He was for a time "chantre" or one of the regular singers in a church at Morges. Having upon at least one occasion appeared in church in a condition far from sober, he was turned out of his position, and went to seek his fortune in Geneva. Here, he made a living by tutoring small boys in grammar, geography, and other subjects. He also taught the French language to several persons of German speech. After some time, he married a woman of the lowest class, who is reported to have been "not so scrupulous as Lucretia" in morals. Several publications of Foigny appeared about this time. One was an almanac, which was remarkably inaccurate even for this sort of book. Foigny also published a set of cards illustrating heraldry, and the Marot and Beza Psalms, with a prayer of his own invention at the end of each psalm. These prayers are characterized as "insipid compliments to the Deity" by a man who read them, and from whom all the facts of Foigny's life are received. ${ }^{5}$ The Usage du Jeu royal de la langue latine of Foigny, a purely grammatical work, was printed at Lyon in 1674 and 1676. Toward the end of 1676, the Terre australe connue was printed. Bayle's correspondent states that it was printed at Geneva, and that the printer admitted having received the work from Foigny. According to the same authority, Foigny stoutly maintained that he had received the manuscript

- Bayle, Dictionnaire critique, ed. 1715, Article Sadeur. There is a note here not included in Article Sadeur of the $1697 \mathrm{ed}$. It is in the form of a letter to Bayle from a person (not named) in Geneva. In Chaudon et Delandine, Dictionnaire universel, $9^{\mathbf{e}}$ ed., Paris, 1810, Article Foigni, there is nothing not found in Bayle's Dictionnaire excepting the sentence: Son voyage romanesque fut très-recherche, tant qu'il fut défendu. 
from Bordeaux, but finally confessed that he had written it himself to obtain money. The title page (see Note 1) reads "à Vannes." That the book may have been printed simultaneously at Vannes and at Geneva is barely possible. It is much more probable that it was printed at Geneva but as if at Vannes, in order to deceive the religious faction at Geneva who persecuted Foigny for its publication. In any event, the book was published in 1676, probably at Geneva, and Foigny was allowed to remain in that city after its appearance through the influence of several German gentlemen whom he had instructed in French.

In a German thesis for the doctorate ${ }^{6}$ mention is made of a copy of the Terre australe connue printed at Geneva in 1676. According to this dissertation, Der Titel der Genfer Ausgabe lautet:

Les avantures de Jaques Sardeur dans la découverte et le voyage de la Terre australe. Genf. 1676.

No other mention of this Geneva edition, with this title, is known to the present author. If Herr Günther's statement is correct, then the Geneva correspondent of Bayle is proved right, and the Terre australe connue was printed in Geneva. That it should have been printed twice in the same year and with two different title pages is of course possible. The entire story of Bayle's correspondent is plausible and convincing in circumstantial details, and can be taken as reliable evidence without the support of Herr Günther. (Another correspondent of Bayle, likewise given space in a note to the $\mathbf{1 7 1 5}$ edition of the Dictionnaire, who believes the Terre australe to have been written by a gentleman from Brittany, must be disregarded, from a lack of those circumstantial details

- Entstehungsgeschichte von Defoe's Robinson Crusoe, Max Günther, Greifswald, 1909, p. 38. 
which indicate the first-hand information of the Geneva correspondent.)

Unfortunately for the reliability of Herr Günther's statements in the dissertation mentioned, a careful study of his disquisition reveals many serious misstatements. "Sadeur" is consistently misspelled "Sardeur" even in quoting title pages. In his treatment of the Histoire des Sévarambes (1677-1679), the Extraordinary Voyage of Denis Vairasse, Herr Günther shows absolute ignorance of the authorship of the novel, and cites no edition in French earlier than 1702, whereas the novel was first published in its complete form, in French, in 1677-1679. It is curious also in a way, that F. Wackwitz, whose dissertation, bearing the same title and date as Günther's, but published at Berlin, although much more complete in bibliography, fails to mention the Geneva edition of the Terre australe connue referred to by Günther.

Foigny was saved from the persecution of the clergy, and permitted to remain in Geneva. His troubles were not to end so soon, however, for he fled from Geneva. some time later, leaving his maidservant in disgrace. He died in a convent in Savoy in 1692.

Foigny's was a tempestuous life, marked by both open: and secret revolt against society and institutions. It would be vain to condone his faults. M. Chinard, in: L'Amérique et le rêve exotique, ${ }^{7}$ points out that a man of Foigny's temperament might have fared better in the newly discovered lands beyond the seas, and that in the physical activity of covering long and strange distances, he: might have found a fitting antidote to his turbulent nature. The facts of Foigny's life show that the only recourse for him was to change from one institution to another in the vain search for freedom of spirit and license in morals. In the Terre australe connue, Foigny goes further 7 Page 201. 
than any of his predecessors in Utopias, and even further than many later authors of this type of novel, in describing a society in which institutions and centralized power are absolutely lacking. In Foigny's ideal commonwealth there is no benign tyrant. There is no ruler, no ruling class. There are no slaves, no class distinctions, no families raised above other families. The means which the hero Sadeur employs to discover this country of equality, and the description of the democracy of Foigny's imagination, furnish the material of the book.

\section{The Adventures of Sadeur}

In the $A u$ lecteur of this novel, ${ }^{8}$ there is a long discussion of man's passion to discover the new and to penetrate into the most difficult truths.

Il veut même monter dans les Cieux: \& non content de raisonner \& discourir des qualitez des étoiles, il s'eforce d'approfondir dans les secrets de la Divinité... on ne cesse depuis quatre ou cinq cens ans de proposer une terre Australe inconnuë: sans qu'aucun jusqu'ici ait fait paroître son courage \& ses soins, pour le rendre connuë.

There follows a discussion of Magellan's discovery of the Tierra del Fuego, found later to be a part of America, and of Gonneville's return to France with a young native "qu'il qualifioit fils d'un Roy de ces Quartiers." " The discoveries of Marco Polo are slightingly considered by Foigny in the light of recent trading in Java by the Dutch, and consequent certain knowledge. One paragraph of the $A u$ lecteur suffices to indicate the sources of Foigny's Terre australe connue.

8 All references are to the Terre australe connue, edition of 1676 . Some later editions are incomplete; the $\mathrm{Au}$ lecteur is lacking entirely in the 1732 edition, for instance.

- Reference has already been made to this young "Australian prince" in Chapter II. 
Il est vrai que comparant la relation de Fernandez de Quir Portugais, avec la description qui doit suivre, on est obligé d'avoüer que, si quelqu'un en est approché, cet honneur lui est deu...

Mention is then made of de Quir's eighth petition to the King of Spain regarding the discovery of Australia in the year 1606. The description of that country made by de Quir and by Paes de Torres, who was the admiral of de Quir's fleet, is also referred to. It is pointed out that these two explorers agree as to the air being si sain . . qu'on y couche à platte terre sans aucune incommodité and further that les fruits y sont si nourrissans $\&$ si excellens, qu'ils suffisent seuls à la nourriture. Further there are good liquors in the Austral land, no clothes are worn, and les sciences naturelles $y$ sont en grands estime. To sum up, Voilà le racourci des rapports de ces deux personnages . . . ils ne particularisent rien.10

Follows an ingenious consideration of the discoveries of de Quir and Sadeur. The Austral Land should by right be claimed by the King of France, as Sadeur was of French parentage. Louys le Redouté \& le triomphant is mentioned. All of this has a distinctly realistic flavor. It is in the same style as the pleading of real travelers, de Quir in his petition, and many others in recounting their discoveries. Discoverers almost always plead in their reports that the new land be claimed by their monarch in Europe.

As to the publication of Sadeur's life and discoveries, we are informed that the writer of the $A u$ lecteur happened to be à Livorgne l'an 1661. Here he witnessed the dis-

${ }^{10}$ It will be seen, after a digest of the description of Australia, that de Quir's petition is very detailed, and that the account of Sadeur agrees time after time with the very details here denied. A wide knowledge of de Quir's petition made this agreement wise if not necessary. 
embarkation of a vessel just arrived from Madagascar. Sadeur, one of the passengers on this vessel, fell into the water, and was rescued in a weakened condition by the writer. By the best of good fortune, it was possible to salvage at the same time Sadeur's personal effects, including his memoirs. These constituted une espece de livre fait de feuilles, long de demi pied, large de six doits, \& épais de deux. After being rescued, the traveler is luckily able to converse in Latin with the writer of the $A u$ lecteur for a matter of two hours before dying as the result of his immersion. Thus are the facts and memoirs of Sadeur's life providentially preserved. The advantage of having an authentic account, rather than an admittedly fictitious account of a remarkable voyage is evident. The public was eager to learn of new lands at this time; books of travel were widely read. Foigny, by his own admission, wrote the story to make money.

The convenience of having the hero Sadeur die immediately on his arrival in Europe is equally evident. Foigny was desirous of passing off his creation, Sadeur, as a real man; and for his purposes a real man defunct was almost necessary. In the Extraordinary Voyages which follow, the dead are always the most brilliant witnesses produced.

Now comes Sadeur's own story of his life. He begins by saying that he writes the history of his life for his own amusement, inasmuch as he has little hope of returning to Europe. The events of his birth and early childhood are known to him only through a memorandum given him by a Jesuit in Lisbon. His birth occurred at sea, his father and mother being on the return voyage to France after having remained some time in the West Indies without profit to themselves. Sadeur says,

I'ay donc été conceu dans l'Amérique, \& je suis né sur l'Ocean, presage trop assuré de ce que je devois être vn jour (p. 3). 
The ship is wrecked near Cape Finistere on the coast of Spain. His father and mother are victims of this catastrophe,-but do not die until they have reached shore and lamented their ill fortune in almost epic fashion. The infant who has been saved by the sacrifice of his parents is commiserated by the other survivors in the following terms:

Pauvre rejetton, que peux-tu devenir? peux-tu avoir quelque bonheur en ce monde, étant la cause si funeste de la mort de ceux qui t'ont donné la vie? (p. 6).

Sadeur is adopted by some natives; but the captain of the ship on which he was born, having acted as his god-father, returns to obtain possession of the child. The Spanish foster-parents take the matter to court. An unfavorable decision causes the doughty French captain to steal the child. A stray shot from a passing Portuguese vessel sinks the boat on which Sadeur and his god-father are fleeing. Only a servant and the child escape drowning. This servant, a model of devotion, goes from house to house trying to find a home for Sadeur and finally arrives with the child at Lisbon. Here he dies, leaving the story and the child with a Jesuit, from whom Sadeur receives years later a written account of his birth and early adventures.

Having thus been the cause of death of each of a series of people taking an interest in him, Sadeur after three uneventful years is adopted by the Countess of Villafranca. He being hermaphroditic, the Jesuit Fathers have decided after careful observation that he shall be brought up as a man. He receives a good education, for he says,

J'appris . . . les langues Latine, Grecque, Françoise, Italienne, \& les principes de l'Afriquaine, la Geometrie, la Geographie, la Philosophie \& l'Histoire d'Espagne avec la Chronologie (p. 13). 
After some quiet years, Sadeur starts from Lisbon to Coimbra, where he is to speak at the University. He yields enough to strong premonitions of danger to travel by land rather than by sea. It avails not at all, for pirates come ashore from their ship, drive off his escort and take him to sea with them.

The pirate ship sinks after a storm. Sadeur floats on the door of the Captain's cabin for some time, and is then seen by moonlight and rescued by a Portuguese vessel bound for the East Indies. He is well treated on board. This vessel puts in at Maninga in the Congo and Sadeur goes ashore on a voyage of discovery.

We are informed at once that the Geographers who place Lake Zair à trois cens lieuës de la mer are in great error. Sadeur declares that he went from the sea to the lake by boat, so many leagues per day for so many days, and that the distance is not nearly so great. He also says that there are no savage and ferocious animals in the Congo, and proves it by the simple statement that he never found any. This he admits.is at variance with the commonly accepted accounts of the region. Having now proved his superiority over the former travelers in the region, Sadeur introduces some wonders of this land which have not been reported previously. Among the many sorts of fish in the Zair, Sadeur found two surprising varieties (p. 28).

Of one variety he says:

ils approchent en quelque chose de nos gros chiens barbets, \& que sortant assez facilement de l'eau, ils sautent presque comme des renards; avec cette difference que leurs pattes sont larges comme les pieds de nos canards.

These fish are so attracted by men that $I l$ arrive même quelquefois qu'ils sautent dans les bateaux. The others are flying fish which paroissoient comme de grandes Aigles 
avec deux aîles, chacune de cinq ou six pieds (p. 29). There are sheep (p. 30) d'vn rouge, d'vn verd, d'vn jaune, \& d'vn bleu si éclatant que nôtre pourpre \& nôtre soie la mieux préparée n'en approche pas."

The Kaffirs are referred to (p. 36) as ces sauvages qu'on ne peut humaniser. The explanation of their ferocity is curious. It seems that a native of the country had progeny by a tigress, and that the Kaffirs are the descendants of this strange cross. The proof of this is that Kaffirs are commonly found to have stripes on their legs. The fact that no other traveler has mentioned the striped legs of the Kaffirs seems to affect Sadeur as little as his own previous statement that there are no ferocious beasts in this vicinity.

After speaking of the brightly tinted sheep and flowercarpeted fields of the Congo, and just before testing our powers of belief with the description of a spring whose water rêjoüit \& fortifie plus que nostre vin d'Espagne, there is a curious protest:

Je m'informay avec beaucoup de soin où étoient les Crocodrilles, que les Historiens mettent en grande quantité en ces quartiers. Mais on ne connut pas meme ce que je voulois dire: ce qui me fit croire que ce n'étoit que des contes faits à plaisir. ... S'il est vray de dire qu'il est permis à ceux qui ont fait de longs voyages d'en faire accroire aux autres qui ne connoissent que le lieu de leur naissance; il est encore plus vray d'assurer qu'ils se prevalent tant de cette licence qu'ils n'affectent presque que des fictions. La raison est qu'il arrive souvent qu'on fait de tres grands chemins sans voir autre chose que quelques ports, où on ne se repose qu'un moment; ... Cependant comme on est persuadé qu'il faut dire quelque nouveauté quand on vient de loin: plus les esprits sont subtils, plus ils en inventent (p. 31).

"I A similar account in l'île imaginaire of Segrais will be recalled. (See Chapter III.) 
The spring which yields a fluid akin to wine he explains by the following unanswerable logic, given as the conclusion of his companions on finding the spring:

si l'on trouvoit des sources de tres mauvais goût, c'êtoit vne suite necessaire qu'on en peât trouver de tres douces \& de tres agréables (p. 33).

After returning to the ship and setting sail, there are no further incidents of note until Sadeur is within sight of Madagascar. Here another storm and another shipwreck enliven the narrative. The geography is also somewhat entertaining to a modern reader. Being within sight of Madagascar when the storm breaks, an East wind blows them

plus de mille lieuës du côté de l'Oüest. Plusieurs virent quelques Isles à la droite vers le Nord, \& les prirent pour celles qu'on nomme de la Trinité (p. 37).

One hopes that Foigny, when he was teaching geography to the small boys at Geneva, confined himself strictly to European countries.

A rock at the surface of the water breaks the vessel in two pieces. Thanks to previous experience (this being his fourth shipwreck), Sadeur cares for himself successfully. He finds a small island near at hand, when he at last regains consciousness. By instinct he had clutched a piece of wreckage immediately after the ship struck. Once on the convenient island, he finds two fruits lying beneath a tree, eats them, and goes to sleep. On awakening, he starts to climb a tree, after the manner of all explorers. He is driven down, however by two enormous birds. He starts to the beach to trust his life once more to the plank by which he escaped drowning the day before, but is attacked by an almost complete menagerie of strange animals. These include: 
certaines especes de chevaux, mais avec des têtes pointuës, \& des pattes qui finissoient en griffes ... elles estoient emplumées $\&$... avoient des aisles (p. 43).

Fleeing to the water, Sadeur escapes upon his plank. Holding one end of it, he progresses at a fair rate of speed, thanks to the animals taking the other end in their teeth and pushing ahead, swimming rapidly in a vain attempt to overtake their quarry. In this way Sadeur reaches and mounts upon a huge object floating at the surface of the water. This island moves ahead rapidly, but soon sinks from view, being in reality a large whale. Sadeur, once more on the sea with only a plank to support him, is again attacked by the winged monsters, which withdraw soon after without harming him greatly. Then, out on the ocean with nothing to support him but his plank, he finds himself

poussé d'un vent de Nordoüest avec beaucoup de vîtesse, bien que sans agitation de la Mer (p. 48).

No other explanation of this rapid progress is vouchsafed. $\mathrm{He}$ comes to another island, finds fruit to eat, and is again attacked by strange animals. These are bears, of whom the following zoölogical fact is noted:

chaque patte me paroissoit aussi grosse que toute la bête (p. 51).

These monstrosities are driven off by the giant birds, one of which clutches Sadeur in its talons and flies high in the air with him. After a considerable journey, this bird puts him down on a convenient rock and another takes him up and continues the journey. Sadeur, tiring of this method of travel, and angered by the pain caused by the beast's talons, finds assez de forces . . . pour luy arracher les yeux à belles dents (p. 53). After a terrific battle with this bird and with another on whose back he 
mounts, Sadeur is seen from shore and rescued by the inhabitants of the Australian Continent (p. 55).12

Before turning to the totally imaginary society of the Australians, which follows this series of adventures, it seems advisable to consider this first part of the story, the Adventures of Sadeur, as distinct from the ideal commonwealth, the carefree land of philosophy, which follows.

The adventurous nature of the part of La Terre australe connue so far reviewed is too evident to be insisted upon. It would be difficult to find a story of no matter what type in which more incidents occur in the same number of pages. There is an obvious interest on the part of the author in the exotic, the new, the shocking and the outrageous. Foigny takes a keen delight in adventure of the exaggerated sort, for its own sake, and totally apart from any philosophic concern, although he draws rationalistic conclusions from time to time. The fact remains that most of the incidents between his birth at sea and his final landing in the Austral land are devoid of interest of a philosophic kind. These incidents are recounted in the same exuberant spirit, and in almost as poor style as those in the Voyages fameux du Sieur Vincent Le Blanc previously referred to.

Murder, sudden death, abduction, shipwreck, strange animals, and strangely fertile countries, have a great attraction for this monk, protestant,t eacher of languages, and ne'er do well, Foigny, - who, as far as is known, never traveled two hundred miles in any direction from the place where he was born. $\mathrm{H}$ s sympathy with the adventurous spirits of the time links Foigny's novel to the exotic spirit of the accounts of real yoyages, in much the same fashion as his interest in the great problems of the human race links his novel to the then ex-

12 The similarity to the Travels of Gulliver is evident. 
istent Utopia of Thomas More and Nova Atlantis of Bacon.

With a man of the exuberant imagination of Foigny, it is useless to expect careful copying of incidents to be evident. That he had read stories of adventure, or talked with travelers, and that he took a lively pleasure in such things is not to be doubted. That an author who evidently invented a large number of the incidents between the last shipwreck and the landing in Australia was greatly indebted to any one source for the remarkable incidents of the youth of his hero is to be doubted. Such an intrepid fabricator of adventure as Foigny can scarcely ever have found himself at a loss for incidents of his own imagining. The first part of his Terre australe connue is much more vague and lacking in convincing circumstantial detail than the first part of the Histoire des Sévarambes of Vairasse, for instance, which, as will appear later, was taken directly from a single detailed account of a real voyage.

With regard to the Congo, it has already been stated that Foigny's methods are largely inductive. He denies distances given by geographers, and proves his claim by stating that he made the distance at so many leagues per day in so many days. He denies the existence of ferocious animals, and proves it by stating that he never found any. The same method is employed with regard to crocodiles. Aside from his own statements of firsthand experience, the only authority Foigny uses is that he learned this or that fact, indefinitely, "from the natives."

It seems easy to believe that Foigny knew the Long and Short Voyages of De Bry which were printed and reprinted at Frankfort.

The idea of the Ruk or great flying bird is one generally characterized as of the Middle Ages That it survived 
into the 17th century in illustrations can be seen by consulting the lifelike engraving ${ }^{13}$ in which Magellan is represented on the deck of his ship passing through the Austral sea, while a giant bird flies off at one side with an elephant in its claws.

It would be futile to argue that all the people of the 17th century in France believed in the existence of these giant birds. Foigny's description of Sadeur battling with them and coming forth victorious must have seemed fantastic and marvelous to most of his readers, as it did to Bayle. ${ }^{14}$ But the existence of such birds was not definitely disproved at the time the Terre australe connue was written. Certainly it was no more difficult of belief than the accounts of brightly tinted sheep, and may be classified with them as an "extraordinary" element.

In the Vera Descriptio Regni Africani, ${ }^{15}$ there are maps showing the rivers Congo, Zair, and Nile flowing out of one source, Lake Zair. Sadeur agrees with this although he alters distances. There is a long description of the Congo, from the voyage of Philippo Pigafetta in this same volume. Except for general terms of eulogy of the richness of the region, there is little similarity with Sadeur's account. It has been shown that Sadeur's method in describing the Congo is that of denying previously reported facts, and claiming first-hand information to be more reliable.

It will be necessary to refer to De Bry's Voyages again

${ }_{13}$ Engraving No. XV, Americae insignis \& admiranda Historia, Pars I, De Bry, Francfort, MDXCIIII. (1594.)

${ }^{14}$ Bayle, Dictionnaire, ed. 1697. Art. Sadeur, pp. 987-988.

La maniere dont il dit que cela fut fait, \& qu'il vainquit les bêtes farouches qui le vouloient dechirer, \& qu'il se retira enfin de ce pais-la . . . est quelque chose de si étrange que je ne pense pas qu'il y ait des inventions plus grotesques ni dans l'Arioste, ni dans Amadis.

${ }^{15}$ De Bry, India Orientalis, Pars I. Francfort, 1598. 
in treating the second, or philosophic, part of the Terre australe connue.

\section{The Austral Land}

The first chapter of Sadeur's residence in the Austral Continent begins with an explanation of his peculiar fitness to report that country for the first time to the people of Europe. Being hermaphroditic, he is esteemed as fit to live by these people, all of whom have both sexes. Furthermore, it is necessary that he arrive totally nude among them, as they consider the wearing of clothes disgraceful. The long battle with the monsters of the air has left him conveniently naked. Without previous experience in shipwreck, he would never have survived to come ashore nude. Lastly, his supreme courage in fighting against the huge birds aroused in the natives an admiration for his virtues, and an appreciation of his fitness to live among them. Under any other circumstances, Sadeur would have been put to death on arrival. A very deterministic sentence is the following:

En vn mot, plus on considerera toutes les circonstances de ce voyage \& de mes perils, plus on y verra êclatter la conduite de Dieu, qui fait disposer de ses creatures pour les faire arriver infailliblement au but qu'elle s'est proposé.

Thanks to his display of courage, to his nakedness, and to his bisexual constitution, Sadeur is taken to the nearest community. Here a place is prepared for him. $\mathrm{He}$ is graciously received, and given blue and red fruit to eat. ${ }^{16}$ His wounds are entirely cured in two weeks by the wonderful balms of these people. The language of the country he masters in five months and with no great effort.

${ }_{16}$ It will be remembered that in the Nova Atlantis of Bacon, the visitors are presented with red fruit immediately on arrival. In both cases it is a reflection of the savages, in accounts of real voyages, 
Sadeur gives the description of the country, which is divided into areas named Hust, Hube, Hump, Hued, Huöd, Curf, Durf, Gurf, etc. Far off at one end of the continent are

vn peuple qui approche fort des Europeens, \& qui vit sous l'obeyssance de plusieurs Roys (p. 61).

Another set of people, divided into thirteen kingdoms, inhabit another side of the continent. These are reported to be continually waging war with one another (p. 63).

Within the region visited by Sadeur, there is a perfect uniformity of language, customs, and buildings. All the mountains have been removed ${ }^{17}$ within the country but on its southern boundary is a huge mountain chain separating these people from the next nation who are like the Europeans. Among the people with whom Sadeur lived, it is sufficient to know one district in order to know them all This is a natural result of the nature of the inhabitants qui sont nais avec cette inclination de. ne vouloir absolument rien plus que les autres (pp. 63-64).

Each house is divided in four, with four men in each quarter. Sixteen men to a house, twenty-five houses to each ward, sixteen wards to each sezain, and 15,000 sezains in the country, is easily computed to make a population of $96,000,000$ people. In each sezain there is a large structure called a $H a b$. It is built of transparent stone and ornamented with a prodigious quantity of figures in all sorts of colors. There are human forms, landscapes, suns and other things represented. This description recalls the decorations in Campanella's City who come to the water's edge with fresh fruit. That Foigny's Sadeur should have fruit of two bright colors instead of one is typical of his method in the "extraordinary."

${ }^{17}$ M. Chinard, in L'Amérique et le rêve exotique, p. 198, says of these mountains, "Les hommes les ont aplanies, tout comme dans l'lle des Corsaires de Gomberville." 
of the Sun, and the way in which the children of that city are educated. But the $H a b$ of the Australians is not a place of education, but a temple. For every four wards there is a $H e b$, built of the same stone as the floor of the $H a b$ - a sort of jasper. The dome is of transparent stone, allowing of illumination. This $\mathrm{Heb}$ is divided into four sections, one for the education of the youth of each ward represented. As soon as a child is conceived, its parent comes to live at the $H e b$, and remains there until the child is two years of age. After this, the parent goes away, and the child is brought up with the other children. ${ }^{18}$

The children are divided into five classes: the first for general principles, the second for reasoning on common things, the third for reason and argument, the fourth for composition; the fifth class simply wait to be chosen to act as Lieutenants, whose function in the community will be explained later. Those living at the $\mathrm{Heb}$ are fed by the people of the wards represented, who are charged with delivering the necessary food daily. ${ }^{19}$

All of this community school, community housing for nursing mothers, and community eating is as old as Plato's Republic and as new as the latest profit-sharing. colony of the twentieth century. It is difficult to determine from which particular "Ideal Commonwealth" Foigny took the details.

There are two remarkable sorts of fruits used by the Australians. One is

${ }^{18}$ Compare "When their women have brought forth children, they suckle and rear them in temples set apart for all. They give milk for two years or more as the physician orders. After that time the weaned child is given into the charge of the mistresses, if it is a female, and to the masters, if it is a male." Campanella, Cily of the Sun, transl. Ed. George Routledge \& Sons, London, 1893.

19 There is a general similarity between the $\mathrm{Heb}$ and $\mathrm{Hab}$ and the temple of the Incas, Le Commentaire royal ou l'Histoire des Yncas. 
de la grosscur des pommes de renettes, d'vne couleur plus éclatante que nôtre pourpre, d'vne odeur charmante, \& d'vn gout incomparable dans l'Europe. Sa proprieté est d'exciter le sommeil a proportion qu'on en mange; aussi est-ce la coltume de n'en manger que le soir (p. 70).

The other fruit is the size of an olive, reddish in color, and comes from a tree called

Balf, ou arbre de Beatitude. Si on en mange quatre on devient gay par excés; en mangeant six, on s'endort pour vingt-quatre heures: Mais si on passe outre, on s'endort d'vn dormir qui n'a point de reveil. Et ce dormir est precedé... du plus grand bonheur du monde ... Ce fruit les fait chanter \& dancer jusqu'au tombeau.

Unless the Australians eat this fruit, or meet with violence, they never die. The similarity between the description of these fruits and the accounts of real travelers regarding opium eating and drug taking in the East Indies is evident. Many accounts of voyages to the Indies mention such sleep and mirth producing drugs, with a statement of the sinister results of an overdose. ${ }^{20}$

There is considerable space given to the geography and topography of the country. The coast slopes so gently that

après une lieuë elle ne fait pas un pied (de profondeur), \& ainsi à proportion.... il est impossible d'approcher de cette Terre du côté de la Mer, qu'à la reserve de quelques veines d'eau qui ne sont connûes que de ceux du Pays (p. 73). ${ }^{21}$

20 There is mention of une herbe qui croist; qui en menjue, si meurt en riant in the Image du monde de Maitre Gossouin, ed. $\mathbf{O}$. H. Prior, Lausanne, 1913, p. 131. Similar accounts in later Voyages simply prove this to be a persistent - and perhaps a somewhat true - story. To say that Foigny imitated the Images $d u$ Monde rather than later authors seems hazardous, however.

${ }^{21}$ This distinctly recalls More's Utopia, which Foigny must have known. 
After having denied the principle that climate varies in northern and southern hemispheres alike, and in proportion to the distance from the Equator, Sadeur claims for the Austral climate an almost complete lack of cold in winter and of heat in summer. There follows a curious argument, which recalls the method used in justifying Sadeur's "discoveries" in the Congo.

Les approches du Soleil y contribuent si peu, que si on y prend garde on sera obligé de conclure, qu'au tems qu'il est plus proche, on experimente qu'il est moins chaud que lorsqu'il est plus éloigné. On sait dans l'Europe que les chaleurs de May \& de Iuin, ne ressemblent pas à celles de Iuillet \& d'Aoust ... . On est souvent gelé en Iuin, lorsque le Soleil est en sa plus grande élevation, \& on est rôti en Juillet, quand il se retire. Il faut donc autre chose que sa presence pour être échauffé (pp. 75-76).

There are no swamps, no flies, insects, spiders, snakes, ni bêtes venimeuses... En vn mot, c'est vn païs... qui est exemt de toutes les incommoditez qui nous environnent (pp. 77-78). After a study of the life, manners, and customs of the Australians, it will be found that this unfortunate people are beset through the greater part of the year with savage beasts, which do not exist elsewhere on earth. The fact that these beasts (which hover over the Australians in the last chapters of the narratives like so many incubi) are not "venimous," is little comfort when these monsters fly down from the air and kill two or three men at a time. In the latter part of the book the huge birds leave Sadeur little time to congratulate himself on the absence of spiders and vermin. ${ }^{22}$

22 The insistence on lack of pests in this part of the book, and from time to time throughout the story, is due to Foigny's indebtedness to de Quir's Petition to the King of Spain, which will be fully discussed later. 
In the following chapter, De la constitution des Australiens \& de leurs Coutumes," we learn that Tous les Australiens ont les deux sexes, \& s'il arrive qu'un enfant naisse avec un seul ils l'étouffent comme un monstre (p. 78). This is of course the converse of the idea of those times, according to which, even as to-day, hermaphrodites were considered as monsters. Unlike many other startling peculiarities of the Australians, mentioned by Sadeur, the hermaphroditism of these people has a philosophic significance. Foigny used hermaphroditism in this imaginary people to do away at one stroke with the evils of love, passion, succession, divorce, marriage, and all such evils as are based upon the fact that normal human beings have one sex. It has been pointed out that in the Hermaphrodites, of 1605, the term "hermaphrodite" was used to signify "effeminate" "foppish," and that the inhabitants of the imaginary floating island were simply exaggerated fops, and licentious dandies. In the Terre australe the term is used in its full biological sense, and the supposition of this imaginary people, each of whom has the two sexes in his person, gives Foigny a weighty cudgel with which to belabor his contemporaries, and with which to attack European society. It will be found further that it serves him to preach feminism, and that he uses it to call into question the doctrine of the fall of Adam.

The legend of a society of people, each of whom had the power to reproduce his kind unaided by another individual is probably a very old one. Like many other legends, it revived from time to time, now here, now there. That it existed in full-blown form in Persia in 1340 A.D. and before is attested by the works of HamdAllah Mustawfi of Qazwin.. ${ }^{23}$ This community of bisexual

${ }^{23}$ The Geographical Part of the Nuzhat-al-Qulub, composed by Hamd-Allah Mustawfi of Qazwin in 740 (1340), 
beings is said by Mr. Le Strange the translator to occur in accounts of Mohammed's night journey. It is perhaps the same legend in another form which is found in the Voyages de Carpin. ${ }^{24}$ In giving an account of the history of the Tartars, occurs:

Ils vindrent à ce qu'on dit en vn certain pays, où ils trouuerent des Monstres ayans semblance de femme; \& comme ils leur vindrent à demander par diuers interpretes, où estoient les hommes de cette terre là, elles respondoient que toutes les femmes qui naissoient en ce pays là auoient la forme humaine, mais les hommes figures de chien.

The resemblance of Foigny's colony to the Amazons of Greek mythology is evident. Bayle ${ }^{25}$ calls attention to the similarity between Sadeur's account of the Australians and that of the Androgynes by Plato.

The reporting of individual cases of hermaphroditism is common in accounts of voyages both to America and to the East Indies. In the Voyages fameux du Sieur Vincent Le Blanc, previously referred to, there is mention of an island (p. 138) where there are

plusieurs hommes hermaphrodites; ce qui semble prouenir de la trop grande abondance de semence, mais imparfaite, causée par les espiceries \& drogues chaudes du pays.

In De Bry, Americae insignis \& admiranda Historia, (Indorum Floridam provinciam inhabitantium eicones etc.), Pars I, Francfort, MDXCI, Tabl. XVII is a representation of "Hermaphroditorum officia." In this engraving, hermaphrodites are being borne on stretchers by the natives of Florida.

transl. G. Le Strange, Luzac \& Co., London, 1919, pp. 266-267. The translator's notes state that the Community in question is mentioned by earlier authors.

${ }^{24}$ Relation des Voyages en Tartarie, Pierre Bergeron, Paris, 1634, p. 348 .

${ }^{25}$ Dictionnaire critique, ed. 1697, Article Sadeur. 
In short, hermaphroditism is one of the commonest of rareties reported by travelers. To say that Foigny gleaned much from any particular account would be vain. No matter what collection of voyages he read, the chance of his meeting references to the existence of hermaphrodites in far-off countries would have been great. In reading a number of exaggerated accounts of real voyages, one is struck with the relatively small number of things about which the human mind finds it possible to prevaricite. Aside from exaggerations of size, color, speed, and extreme longevity, there only remain the "dolphin in the woods, the boar in the sea" referred to by Horace, and accounts of sex perversions. Of these last, there are numberless cases of man-animal crosses, and of children brought up by animal foster-parents. A woman mating with a bear, a woman mating with a monkey have been mentioned in Le Blanc's Voyages. Foigny explains the origin of the Kaffirs by the mating of a man with a tigress. The legend of Romulus and Remus and the Mowgli of Kipling's Jungle, separated by over twenty-five hundred years, should be sufficient proof that these exaggerations comprise a folk-lore that is static on the frontiers of civilization, where men and animals meet in a sense as peers.

An interesting legend of hermaphroditism in France is cited by Bayle..$^{6}$ He says,

Je me souviens à ce propos d'avoir lu dans la Bibliotheque Françoise de Du Verdier (p. 728), les vers suivans:

J'ai veu vif sans fantosme

Un jeune Moyne avoir

Membre de femme \& d'homme

Et enfans concepvoir

26 Bayle, Dict. Crit., ed. 1697, p. 988, Notes. 
Par lui seul en lui-même

Engendrer enfanter

Comme font autres femmes

Sans Oustil emprunter.

Ils sont tirez d'un poëme de Jean Molinet intitulé, Recollection des merveilles advenuës de son tems.

That Foigny knew this poem, or rather the story contained in it, as a legend of monasteries in France, is easy of belief. Regardless of whether he knew this legend, whether he knew any particular account of hermaphroditism in accounts of voyages, or knew the political and moral satire, Les Hermaphrodites, he must be given credit, for having used an imaginary society of bisexual beings in a far-off and little known continent, as a basis for "philosophic" or rationalistic argument. Of this last there is plenty and to spare in the chapters in which Sadeur sits at the feet of the "bon vieillard" and hears the reasoning of an unenlightened Deist.

There remain a few remarkable features of the Australians, which should be considered before coming to the philosophical and argumentative part of the book.

Foigny allows his hero Sadeur to report that the Australians are of a color qui tire plus sur le rouge que sur le vermeil (p. 78). Relatively few people had shared with Malherbe the privilege of seeing the Brazilians at Paris, ${ }^{27}$ and some of Foigny's readers may have believed this statement. Other features of the Australians such as the remarkable fact that some had a sort of tail (p. 79) are thrown in purely to excite interest, and are never mentioned in the remainder of the story. With a lack of style that is surprising if not commendable, Foigny gives all the startling features of the country and people

27 For an account of Brazilians in Paris, cf. G. Chinard, L'Amérique et le rêve exotique, Paris, 1913, pp. 22-23. 
in his imaginary Australia in the first chapters of his account. Only those features are again referred to which have necessarily to be mentioned in order to authenticate the story, or to make escape from the country at the end of the story seem fitting and possible. That this lack of coherent exposition is common to both this novel in particular and to accounts of voyages actually made, is an interesting link between Foigny and that gorgeous liar Vincent Le Blanc. (The careless style of Le Blanc, who is typical of the exaggerated real-voyage school, is epitomized in the following. After describing the beauties and riches of Goa ${ }^{28}$ with great enthusiasm, he gives as a sort of after-thought the fact that they have small-pox, cholera, scurvy, and other diseases.) The addition of a huge amount of social and philosophical matter in the Extraordinary Voyage occupies the space which in accounts of real voyages is given to trade in this or that sort of merchandise, descriptions of markets, ports, customs houses, and matters pertaining to passports, and favorable seasons.

The manner in which the Australians reproduce their kind remains a mystery to Sadeur throughout his stay among them. Each individual is obliged to present one child to the $H e b$, to be educated, but it is a crime among them to speak of the manner in which children are conceived. Jamais je n'ay pu connêtre comme la generation $s^{\prime} y$ fait (p. 79). Bayle regrets this lack of precision in the account of Sadeur. ${ }^{29}$ The following is a fair example of the adaptation of the real voyage with the purpose of criticizing European civilization.

Ils ne sçavent ce que veut dire le mien \& le tien, tout est commun entre eux, avec une sincerité si entiere: que l'homme \& la femme

${ }^{28}$ Les Voyages fameux du Sieur Vincent Le Blanc, Paris, 1648, p. 76.

29 Bayle, Dict. Crit., ed. 1697, p. 988. 
n'en peuvent avoir une plus parfaite parmi les Europeens (p. 80). ${ }^{30}$

For his inquisitiveness in matters of sex, Sadeur is in danger of death at the hands of the Australians, and is only saved by the plea of a venerable old man who witnessed his extreme bravery in fighting the birds on his arrival. The manner in which Sadeur accuses the Australians of pretending to keep silent about sex matters, and the means he takes to overcome the scruples of one Australian accords well enough with what is known of the moral character of his creator, Foigny.

The old man, who labors under the name of Suains, takes Sadeur aside and says,

Il n'est qu'un expedient que je te propose... qui est que tu viennes avec liberté me découvrir tes doutes, \& je te donneray toute la satisfaction que tu pourras souhaiter, pourveu que tu sois discret (p. 82). ${ }^{3 l}$

Naturally, the comparison of Europe and Australia is now upon us. Suaïns concludes from an account of the diet of Europeans that it is only natural that these benighted beings never live beyond a hundred years. $\mathrm{He}$ contends further that a human being devoid of either of the two sexes cannot reason, because he is imperfect to begin with. Sadeur retorts by comparing man to the other animals. From this analogy he asserts that persons having only one sex are natural, while hermaphrodites are monsters. This gives Suaïns the chance he has been waiting for, and he answers,

${ }^{30}$ That such statements are to be found in Le Blanc's Voyages has already been pointed out.

${ }^{31} \mathrm{M}$. Chinard, in L'Amérique et le rêve exotique, has pointed out that the venerable old man is a stock character in the relations of the missionaries. It is always this character who takes the visitor aside and explains the language and people. 
Ton raisonnement vous suppose ce que nous vous croyons, a savoir des bêtes (p. 88).

There follows a long harangue in which Suains bases the difference between animals and men (of his kind) on the fact that man is perfect and sufficient to himself, whereas the beasts are taken up with the business of mating. Sadeur, upon reflection, is convinced of the justice of this statement, and of the brutality and bestiality of Europeans. The good Australian, upon learning the rights of fathers in Europe, is astonished that women should be so downtrodden, considering that the burdens of the world are upon the mothers and not upon the fathers. Sadeur is thus convinced that

ce grand empire que le mâle avoit usurpé sur la femelle étoit platôt une espece de tyrannie, que de conduite de Iustice (p. 95).

Bayle quotes from Mademoiselle Bourignon ${ }^{32}$ a passage "revealed to her by God" in which Adam is said to have possessed the two sexes originally. He reproduced his kind, unaided, by the simple expedient of praying to God. The natural processes then took place within him. One quotation from this strange visionary may be given (as cited by Bayle) from its similarity to the spirit of the Sadeur version.

C'est ainsi que dans la vie éternelle il y aura une generation sainte \& sans fin, bien autre que celle que le peché a introduite par le moyen de la femme. ${ }^{33}$

There is no certainty that Foigny knew of the visions of Mademoiselle Bourignon, ${ }^{34}$ but protest against those natural laws which govern both men and animals, going hand in hand with protest against the downtrodden

32 Bayle, Dict. Crit., ed. 1697. Article Adam, p. 94.

$\$$ Id.

34 This strange visionary, Antoinette Bourignon, was born in 1616 and died in 1680. 
estate of woman, constitutes the feminist point of view of both. In the Histoire des Sévarambes of Vairasse, one comes to the opposite pole of polygamy, but in the Terre australe connue, there is definite feminism.

The wars and massacres of Europe are harshly judged by Suains to be the result of a spirit akin to that of the Fondins, who are des Barbares dont le Pays confine celui des Australiens. According to Australian standards quarreling among men is impossible by definition, for reason and quarreling do not go together. In the words of Suaïns, Comme le Soleil ne peut être Soleil qu'il n'éclaire . . ainsi l'homme ne peut être homme qu'il ne differe des bêtes (p. 97).

Equality in education in Australia does away with any possible source of quarrels. Jealousy and hatred are considered natural results of unequal advantages.

The wearing of clothing fills Suains with horror; he cannot even be reconciled to the idea upon the basis of a cold climate.

Il faut être pis que bête pour faire séjour où on n'est accueilly que de maux, sur tout quand ils sont mortels (p. 101).

Of clothing as an aid to morality, the worthy man cannot be persuaded. He compares Europeans to les petits enfans qui ne connoissent plus un objet aussi-tót qu'il est voilé (p. 102). All of this so impresses Sadeur, that he says

J'écoutois cet homme plûtôt comme un Oracle, que comme un philosophe... A voir ces gens, on diroit facilement qu'Adam n'a pas peché en eux (p. 103). ${ }^{35}$

With regard to liberty, Suaïns has very definite convictions.

35 The relation of Foigny's ideal people to the doctrine of the fall of man, through Adam, is of great interest to Bayle. 
L'essence de l'homme consistoit en la liberté, \& la lui vouloir otter sans le détruire, c'étoit le vouloir faire subsister sans son essence" (p. 107).

This liberty is based upon equality. Suains said that: c'étoit de la nature de l'homme de naître libre: qu'on ne pouvoit l'assujettir sans le faire renoncer à soy même... l'homme ne peut naitre pour le service d'un autre homme,... s'il arrive qu'on le lie, \& qu'on le captive, il perd bien le mouvement exterieur de sa liberté, mais l'interieur ne diminuë point (pp. 107-108).

The superiority of the Australians over the Europeans is nowhere more clearly demonstrated than in the long reflection of Sadeur upon the relative merits of the two peoples (pp. 109-110). He says that after a long conversation with Suains,

J'entray au Hab, ... admirant les connoissances \& les grandes lumieres dont ce peuple étoit remply ... Il me sembloit que plusieurs écailles étoient tombées de mes yeux ... Ie ne pouvois que je n'admirasse leur conduite opposée à nos deffauts.

Again, having spoken of the lust, murders, dissensions and imperfections of Europeans (p. 111),

enfin quand je me voyois obligé de confesser que la passion nous conduisoit beaucoup plus que la raison; je l'avouë, j'admirois ce peuple, \& je souhaitois que l'exemple d'un vray homme pat servir à confondre la vanité de plusieurs, qui faisant gloire d'être éclairez des lumieres surnaturelles vivent comme des bêtes: pendant que ceux qui ne sont conduits que de l'humanité font parêtre tant d'exemples de vertu (pp. 111-112).

This is more than rampant Deism. It is the expression of a wish that Deism and rational religion might supplant the revealed religions and also, a thinly veiled attack on the missionary spirit of the time in Europe. 
Chapter VI (p. 159) bears the title "De la Religion des Australiens." The Australian belief is a very delicate subject. It is an unheard-of crime among them to speak of it, either to discuss it or in order to enlighten any one. It is only the mothers, who, with their first teaching, include that of the Haab, c'est à dire l'Incomprehensible (p. 112). They hold that this Incomprehensible permeates everything, and further that it greatly offends this Deity to discuss his divine perfection, to praise him or to pray to him for anything. In short leur grande Religion est de ne pas parler de Religion (p. 112). Inasmuch as they do not attempt to define the Incomprehensible, the Australians prefer to keep silent on such matters rather than to make false statements and cause the endless quarrels and disputes which must result from such discussion.

Suains, however, is an exception. In order to instruct his protégé Sadeur, he discusses religion with him at length (pp. 114-136). Suains is a Deist. He protests against the theory of atomic materialism, current at the time among free-thinkers in France.

Rapporter tout ce que nous voyons à des cas fortuits, qui n'ayent aucun autre principe qu'un mouvement local, \& le rencontre de plusieurs petits corps: c'est s'embarasser en des difficultez qu'on ne resoudra jamais, \& se mettre en danger de commettre un blaspheme execrable (p. 115).

Belief in le grand Architecte \& le supreme Moderateur (p. 115) is considered by the Australians as le fondement de tous nos principes. They do not believe that this supreme Being, the $H a a b$, acts in particular matters. His actions are only universal. To statements that there have been revelations to several peoples, Suains retorts:

Mais comment croire, que le Haab a plustôt parlé aux uns qu'aux autres? Et d'où peut provenir ... qu'il prefere plustôt 
les uns que les autres, pour les favoriser de ses lumieres? (pp. 123-124).

Notwithstanding all the pious declarations in the novel, Suains always answers Sadeur, and the latter never refutes the Australian beliefs. Foigny speaks through the mouth of Suains, and not through that of Sadeur. ${ }^{36}$

That Deism, in fact if not in name, existed among freethinkers in France at the time the Terre australe connue was written, is well recognized. Rationalistic processes of thought and revealed religion have always made strange bedfellows. That deistic ideas must have received stimulus in France from accounts of strange peoples is perhaps less appreciated. The reasoning of Manco Capac, one of the Inca Kings, and the belief of the initiated among the Incas in an incomprehensible and invisible God, the Pachacamac, has been mentioned in Chapter II of this study in treating the Commentaire royal, translated from the Spanish of Garcilaso in 1633. Other editions of the Commentaire royal in 1658 and 1672 are ample proof of its popularity. In 1634 there appeared in Paris the Relation des Voyages en Tartarie, of Pierre Bergeron. In this occurs an Asiatic counterpart of the South American religion. Of the Tartars, one reads:

Pour ce qui est de leur Religion, ils croyent vn Dieu Createur de toutes choses, tant visibles qu'inuisibles, \& qui donne les recompenses \& les peines aux hommes, selon leurs merites, Et toutesfois ils ne l'honorent pas par prieres \& loüanges, ny par aucun seruice \& ceremonies. (Voy. en Tartarie, ch. iii, p. 323.)

36 There is a vague general statement that the Australians believe in the transmigration of souls. It is only mentioned once, and Sadeur says it was explained to him:

d'un air si relevé que je ne pâs retenir ce qu'il me dit, bien qu'en l'écoutant, je comprissc en quelque façon toutcs ses propositions (p. 136). 
A similar report has already been referred to in the Voyages fameux du Sieur Vincent Le Blanc, 1648.

Whether Foigny knew any or all of these accounts of deistic religion in far countries, or whether he followed the abstract reasoning of other free-thinkers of his time in France, is of course secondary in importance. The chief interest in the Deism of the Terre australe connue in the present study lies in the fact that Foigny used an imaginary people whose religion is Deism, to criticize the religious quarrels in Europe, and to attack revealed religion. Jean Beaudoin, in translating the history of the Incas from the Spanish, and Bergeron in editing the Voyages en Tartarie and the Voyages of Le Blanc had undermined the foundations of revealed religion, or in any case had given weapons to those who chose later to attack it. With Foigny, the attack is conscious, carefully thought out, and therefore more dangerous. As long as religious differences in Europe were confined to interpretations of a single revelation, there existed only orthodoxy and heterodoxy. Among the heterodox were the free-thinkers. It would seem likely that the number of free-thinkers did not increase by pure accident in France in the same period with the first favorable presentation of other revelations conflicting with Christian theology. Thanks to reports of peoples living in peace and in righteousness, who had never had a revelation of any sort, such as the Incas and (in some reports) the Tartars, it became possible to defend Deistic ideas by appeal to precedent as well as to reason. The elaboration of Foigny upon this basis, and his creation of an imaginary people capable of examining, appraising, and rejecting the revelation known in Europe, is a dangerous step. M. Lanson has pointed out ${ }^{37}$ the similarity of Foigny's

${ }^{37} \mathrm{G}$. Lanson, Origines et premières manifestations de l'esprit philosophique, etc. Revue des Cours et Conférences, Avril 1908, pp. 146-147. 
rationalism to that of Spinoza, and has taken this as probable proof that Foigny knew the ideas of Spinoza, even if he did not know Spinoza's Ethique, which was published only in 1677.

A statement similar to that found in the History of the Incas and to that of the Australians of Foigny's imagination is to be found in the works of Saint-Evremond. In his Iugement sur les sciences oì peut s'appliquer un honnête homme, ${ }^{38}$ published without name of author, together with some satires of Boileau, in Paris in 1666, occurs the following:

La Théologie me semble fort considérable, comme une science qui regarde le salut; mais, à mon avis, elle devient trop commune, et il est ridicule que les femmes même osent agiter des questions qu'on devroit traiter avec beaucoup de mystère et de secret. Ce seroit assez pour nous d'avoir de la docilité et de la soumission.

That this was a natural reflex of too much rationalistic patter at the time goes without saying. It is, however, difficult to believe that the published voyages of the time were without effect in this growing rationalism.

Among the Australians, as reported by Sadeur, there is a complete absence of diseases. Even child-birth is painless among these sane, sensible people, who eat soberly, and only fruits. Because of their diet they are free from passions, and, by extension, from bile, humors, and other weakening causes.

The certainty that others will renounce living, and the consequent necessity of parting with friends, causes the Australians to see the futility of loving any person or thing to excess. They are therefore glad when their

28 Saint-Evremond, Euvres Mêlées, Paris, 1865, t. 1, p. 57. (Ed. Techener Fils.) 
turn comes to find a lieutenant to take their place. When one of the "brothers" in this community has lived a hundred years or more and no longer cares to exist, he selects a young man of at least thirty-five (at which age the formal education of the people ends) to replace him on earth. The elder man is then permitted to eat of the proper fruit in the proper quantity, and dies joyously, as previously explained. This manner of looking at life and death (which is mentioned only once in the book) is strongly tinged with pessimism - such as that of Job in the Old Testament. Even in this wonderful civilization of theirs, men are glad to be at rest, far from the world and its ways.

Perhaps Foigny unwittingly gives the clue here to the failure of all systematized and prearranged schemes of life and society. If we had no cold weather, no vermin or pests, no unhealthy food, and no diseases to kill us, if all our goings and comings were regulated to a stroke of the bell, we should weary of the monotony nevertheless after a century or so, and welcome the convenience of the Balf-tree, much as the worthy Australians.

The day is divided into three parts of five hours each, among these people: from 5 to 10 A.M., from 10 A.M. to 3 P.M., and from 3 to 8 P.M. The night is undivided, as the whole community sleeps soundly after taking several sleep-producing fruits. The population is divided into four shifts. These alternate in the three divisions of the day so that the monotony is recurrent rather than fixed. In the $H a b$ or temple, they remain five hours without speaking, lost in ascetic contemplation of the mysteries of heaven and earth. Others argue and reason at the $\mathrm{Heb}$ or place of instruction. The second part of the day is devoted to work in the gardens where flowers are cultivated. Fountains, troughs, and basins have to be kept in order. By spraying fruits with certain fluids 
an especially delicious flavor is imparted. The third part of the day is devoted to public functions. First, there are physical exercises with the sword, with weights, and with balls. After this, new inventions are explained. With regard to these, Sadeur says (p. 160), En 32 ans qu'il y a que je suis dans ce pays, j'en ay remarqué plus de cinq milles, qui passeroient pour des prodiges entre nos meilleurs esprits. Those listed by Sadeur include growing flowers from lifeless pieces of wood, creating a bird from earth moistened with a certain liquor and warmed by the sun, and creating a little dog by almost the same process. Materials are mysteriously hardened and softened and water is magnetized. One of the "brothers," or inhabitants of this perfect land, makes himself invisible for two hours by virtue of sea-water mixed with juice taken from the fruits cultivated in the gardens (pp. 161164).

The use of sea-water in many of these experiments, together with the creation of living plants and animals, is strongly tinged with the magic of the Hindus, who use the sacred waters of their rivers to perform wonders for the admiring populace. The street magicians of India and of China have performed similar feats for a thousand years. That they were known to perform feats of magic in these countries appears in many 17 th century accounts of voyages to the East. It would be futile to contend that Foigny took his examples from one rather than another. Further, it is likely that he invented from his own imagination some of the twelve cases he cites.

Chapter IX is devoted to the languages of the people, a monosyllabic language in which each letter has a meaning. The words are necessarily self-explanatory for vowels represent the elements, and consonants are adjectives. Children learn the composition of objects at the same time that they learn how to spell. As the 
singular of the verb "to love" is conjugated "la, pa, ma," it is only fitting and proper that the plural should be "lla, ppa, mma." When the one past tense is given, it is rather difficult to pronounce "he has loved" - which is spelled "mga." As for the third person plural, "mmga," it must be admitted that the Australians are in their enunciation what Sadeur says of them as to their athletic exercises: d'une grande agilité.

Perhaps the better to escape the eyes of those certain to criticize the book, there is tucked away in this chapter a very important bit of rationalistic argument. Notwithstanding Sadeur's preliminary statement that in their ancient history ils font parêtre de la foiblesse, $\&$ de l'extravagance (p. 174), there is satire intended. First, their creation dates from twelve thousand years before, contrary to the Biblical tradition. Then, Ils ont de vieilles êcorces qu'ils estiment de huit mille revolutions: \& on $y$ distingue leurs annales (p. 174). As for the first. five thousand years. of their history, Sadeur remarks jamais je n'y ay pa rien comprendre. As for these books: of sacred history, la seule raison ... pour autoriser la verité de ce qu'ils contiennent, est que ce sont des hommes: qui les ont êcrits, qui êtant incapables de tromper, ont consequemment remarqué ce qui se passoit alors (p. 175). The conclusion which follows is ingenious:

Mais si ce qu'ils apportent êtoit vray, 'les êtoiles seroient multipliées des deux tiers, le Soleil grossy, \& la Lune fort diminuée: la mer auroit changé de place, \& mille chóses pareilles: qui sont hors de toute apparence (p. 175).

That this is a thinly veiled criticism of the Old Testament as an authentic document is evident.

The questioning of the authenticity of the Old Testament was, of course, only a natural result of study of theories of the creation according to other traditions. 
As long as only one theory of the creation was known in Europe, it was not easy to doubt it. When, however, the traditions of other nations became known, doubt of the story of Genesis sprang up, just as did demonstrable Deism. While it is not impossible at all that Foigny knew the Traicté des Tartares of Pierre Bergeron ${ }^{39}$ the quotation which follows is submitted rather as an example of similar divergence from the book of Genesis than as an absolute source of Foigny's ideas in the Terre australe connue.

According to the Tartar computations, their monarchy is very old. Their account feroit commencer leur Monarchie prés de 300 ans auant le deluge; chose du tout fausse \& absurde; il faut releguer cela auec les fabuleuses Dynasties des Chaldées \& Egyptiens. ${ }^{40}$ Bergeron continues that it would be impossible for the Europeans (who are by their own admission more civilized than the Tartars) to keep so long a record and still avoid les origines fabuleuses ... sans l'aide d'vne plus haute \&. certaine connoissance que nous fournit la parole de Dieu.1

That Foigny took this account, or some other similar to it, and changed it about to suit his own purpose in ridiculing the story of Genesis and the Old Testament, is very easy to believe.

Similarity between the account of the ancient history of the Tartars and that of the Australians is far from being proof that Foigny knew this particular Traicté des Tartares. That he knew this Traicté can be doubted. Foigny may have based his story of the Australian traditions on any of a number of traditions reported by travelers to the East. He may have based it upon criticism of the traditions of the Egyptians and Chaldeans,

39 Paris, 1634. An analysis of Voyages to Tartary.

10 Traicté des Tartares, pp. 143-144.

41 Traicté des Tartares, p. 145. 
or other peoples, written in good faith by the progressive clergy in France and other countries. ${ }^{42}$ M. Lanson has pointed out the use of rationalistic method on the part of the clergy in France at about the time the Terre australe connue was written, and the comparison of other religious history with the orthodox Christian tradition - of course to the glory of the latter..$^{43}$

The interesting and important fact in Foigny's criticism of the story of Genesis is that he used the traditions of another people, and a rationalistic method of thinking, to arrive at a very dangerous satire. Free-thinking and rationalism needed just this knowledge of other peoples and other religious traditions to enable them to put forth a demonstrable denial of Christian doctrine. To the present author, it seems that perhaps too little importance has been attached in the past to the philosophic material furnished by the accounts of real voyages. That such material is used as a weapon against Christian teachings by Foigny in his fictitious voyage is one of the most important facts concerning the Terre australe connue.

According to Australian belief and written tradition, the Europeans, who only have one sex, are "demihommes" and similar to beasts who have the same characteristics. Long ago, a complete human being (having the two sexes) was seduced by a snake. The snake and this person swam to another part of the world together. Of this union, a pair of children were born, one a man (in the European sense), one a woman. These monsters ate fish, flesh, and other things commonly eaten by savage beasts, and became more and more like

12 See G. J. Vossius, De vera aetate mundi, The Hague, 1659.

* G. Lanson, Origines et premières manifestations de l'esprit philosophique, Revue des Cours et Conférencss, 1908. The Demonstratio evangelica of Huet, and criticism of it in the Journal des Savans, January 9,1679 , are referred to. 
animals. Here is a keen bit of satire on the origin of man according to Genesis. It fits particularly well with the story of the uncorrupted Australians still living in their Eden, far from sorrow, care, and the evils of the flesh. Bayle remarks ${ }^{44}$ that the Australians of the Terre australe connue

ne descendent point d'Adam, mais d'un Androgyne, qui ne dechut point comme lui de son état d'innocence. Ce tour-là seroit assez bien imaginé pour tromper la vigilance des Censeurs de livres, \& pour prevenir les difficultez du privilege, en cas qu'on voulât faire tenter fortune à un systême Preadamitique.

He also calls attention to the similarity between the Australian legend and the old heresy of Eve bearing two children to the snake that tempted her. In the Article Adam of Bayle's Dictionnaire, of the same edition, ${ }^{45}$ is recorded another curious heresy - that Adam and Eve were united, after the fashion of monsters of the "Siamese-twin" type, and that God made Eve from Adam's side by cutting the bond of flesh that bound the two together. It is probably to somewhat similar heresies that $M$. Lanson refers in this connection ${ }^{46}$ in saying plusieurs rabbins ont considéré Adam comme ayant les deus sexes avant son péché. That Bayle goes on in his Article Sadeur to discuss the Androgynes of Plato and the translations of Plato into French has no great importance in the present study. Doubtless Foigny was aware of the heresies preached by the rabbis, and he probably knew the ideas of Plato. That he had so thorough a knowledge of the literature of hermaphroditism as had Bayle is easy to doubt.

4 Bayle, Dict. Crit., ed. 1697, p. 989.

${ }^{45}$ Bayle, Dict. Crit., ed. 1697, p. 95, Note F.

${ }^{45} \mathrm{G}$. Lanson, Origines et premières manifestations de l'esprit philosophique, Revue des Cours et Conférences, Avril 1908, p. 145. 
Chapter $\mathrm{X}$ of the Terre australe connue gives an account of the animals of this remarkable land. After a short allusion to the absence of snakes in Ireland, wolves in England, and other curiosities, Sadeur brings in again the absence of all sorts of worms, spiders and snakes in this happy land. The natives can sleep on the bare ground, and fruits can grow undisturbed to a luxurious maturity, because of this negative blessing.

There is description of a sort of monkeys, formerly used as pets by the natives. These are now prohibited as they interfere with the serenity of the meditations in the Hab. Pigs of a remarkable sort are found. They have very long snouts and are geometrically inclined.

Ils ont cette addresse de foüir \& renverser la.terre en lignes droites, avec autant $\&$ plus d'artifice que ne font nos meilleurs laboureurs; ... ils n'ont besoin d'aucun conducteur pour commencer, continuer, \& finir leurs raies (p. 181).

The unfortunate part of all this is that they can only be used a few days a year. The rest of the time they must be carefully shut in to keep them from ploughing up the entire district. Another curious animal is a camel with a sack hanging in his back instead of a hump protruding from it.

L'échine de leur dos est enfoncée par tout, \& les côtes qui s'élevent au dessus font une espece de cœur, dont la pointe est en bas, \& on couche facilement deux hommes dans le creux de dessus. On les nomme Fuëfs (p. 182).

There are also birds called Effs which sing sweetly, follow the natives about, and cry to give warning to their masters of the approach of the winged enemies of the Australians.

These creatures, called urgs, make war on the Australians a large part of the year. They are: 
de la grosseur de nos Boufs, ... avec un bec d'un grand pied, plus dur \& plus affilé que l'acier aiguisé. Ils ont ... deux grandes oreilles, de plumes rousses \& blanches, ... un corps long de douze pieds, \& large de quatre, avec une queuë de plumes grandes... des pattes... finissantes en cinq effroyables 'serres capables d'enlever facilement un poids de trois cens livres.

There follows a chapter describing the wars of the Australians with their uncivilized neighbors. Another recommends the importation to Europe of some of the useful beasts of the "agricultural swine" type. After these realistic and prosaic chapters, comes a prolonged description of the constant state of war between the Australians and their winged enemies the Urgs. It is indeed well that there has already been given the description of the uneventful life of these almost perfect people, whose even lives are divided between the meditations of the $H a b$, the arguments of the $H e b$, and the delightful flower-gardens and athletic pastimes. In the latter part of the book, what with the ghastly war of the Fondins (the savage neighbor nation) and the continual attacks of the Urgs, there is little time for meditation and none for the cultivation of the gardens, one would think.

This is indeed reminiscent of the abrupt changes of the accounts of real voyages. With astonishing lack of feeling for the effect of the whole, Foigny leaves the placid and meditative life behind, and plunges his hero Sadeur once more into the turmoil of an extraordinary and peripatetic life of adventure.

Before leaving the ideal Australia and replacing it by the parlous Australia of battles with Fondins and Urgs, should come the consideration of Foigny's indebtedness to previous accounts of discovery in Australia. In the India Orientalis of De Bry previously cited with reference to Sadeur in the Congo there is a Latin version of the Petition of de Quir. Part of the title of this 
work reads: in causa detectionis quintae Orbis terrarum partis, Terrae nempe Australis incognitae. ${ }^{47}$

Inasmuch as the Grands Voyages and Petits Voyages of De Bry were published in Frankfort, and for a period covering many years, it is not to be doubted that Foigny knew of them. Also, the fact that the description of the Congo stands with the Petition of de Quir in the collected India Orientalis of De Bry would lead us to suppose that Foigny perhaps knew of de Quir through the medium of this collection rather than through the French translation.

This Petition is fairly well known. It has been referred to in connection with the $A u$ lecteur of the Terre australe. The style of the discoverer is elevated and enthusiastic. Australia is presented as a land free from almost all the troubles existent elsewhere. Perhaps the indifference of the King of Spain to repeated petitions may be responsible for some of the promises made by de Quir for the land unknown. In any event, this eighth petition begins with a lament: Serenissime potentissimeque Rex, Domine Clementissime, Ego Capitaneus Petrus Fernandus de Quir, dico hunc esse octavum libellum supplicem, quem Maiestati tuae offero. ${ }^{48}$

Of the people we read: ${ }^{49} A c$ nec artes habent, nec muros, nec Regem, nec legem, and of the productivity of the soil: ${ }^{50}$ Fructus in hoc tractu quamplurimi sunt \& eximie boni . . . magna est ibi porcorum copia. This is of course not proof of Foigny's indebtedness to de Quir, for fruit in large quantities is the report of all travelers in all continents, and swine are reported in many voyages to China and the Malay peninsula as well as those to Borneo, Java, and Sumatra.

The insistence of Foigny upon the absence of insects, and the similarity of his topography to that of de Quir,

"India Orientalis, Pars X, p. 13. Francfort, 1613.

${ }^{88}$ Id., p. $13 . \quad{ }^{49}$ Id., p. 14. 
can leave little doubt, however, that Foigny took pains to agree with the Petition. The fact that the Petition was well known, and that it appeared not only in de Bry's India Orientalis but separately in Spanish and French, made it distinctly to Foigny's advantage to agree with it in some particulars, in order to substantiate his otherwise fantastic story of the Austral land. The statement cited from the $A u$ lecteur of the Terre australe connue (that de Quir and Paes de Torres "ne particularisent rien") should be borne in mind. In de Bry's version of de Quir's Petition occurs: ${ }^{51}$

Nulla nobis conspecta sint sabuleta, nulli cardui spinosaeue aut radicibus supra solum porrectis arbores, nullae prorsus lacunae, nullae paludes, nullae in montibus nives aut noxii vermes, nulli in fluuiis crocodili, nullae domibus pariter frugibusque, detrimentosae formicae, erucae, culices, \&c. dico hanc esse praerogatiuam super omnes dignitates . . ${ }^{52}$

In the Terre australe connue of Foigny occurs (p. 72): ce grand Pays est plat, sans forêts, sans marais, sans déserts. The even temperature has already been referred to. With reference to insects and poisonous creatures, Sadeur says (p. 77):

On n'y voit ny mouches, ny chenilles, ny aucun insecte. Ils ne savent ce que c'est qu'araignée, que serpens, \& qu'autres

${ }^{61}$ India Orientalis, Pars X, p. 17.

${ }^{62}$ In Purchas, His Pilgrimes (vol. xvii, pp. 228-229) occurs the following version of this passage:

We have not seen any barren and sandie ground, not any thistles or trees that are thornie, or whose rootes doe shew themselves, no Marshes or Fennes, no snow upon the mountains, no Snakes or Serpents, no crocodiles in the Rivers, no Wormes that use with us to consume our Graine, and to worke us so much displeasure in our houses, no Fleas, Caterpillars, or Gnats. This is a Prerogative that hath the advantage of all the priviledges ... (that nature hath bestowed on other places). 
bêtes venimeuses; en un mot c'est un pays ... qui est exempt de toutes les incommoditez qui nous environnent.

Even this is repeated as if by design throughout the story, especially with regard to insects:

ce bon homme [Suaïns] n'admira rien plus que les moucherons, les poux, les puces: ne pouvant comprendre comment de si petites pieces joüissent de la vie (p. 84).

les menuës vermines que les Australiens ne peuvent comprendre (p. 179).

je dois mettre entre l'un des premiers bonheurs des Australiens, qu'ils sont si universellement exemts de tous ces insectes (again p. 179). ${ }^{53}$

It will be remembered that Sadeur denies the existence of crocodiles in the Congo, and ridicules previous reports that there were crocodiles there. De Quir states that there are no crocodiles in the rivers of Australia. It is barely possible that Foigny's ideas of geography were vague enough for him to take the statement regarding

53 M. Günther, in Entstehungsgeschichte von Defoe's Robinson Crusoe, Greifswald, 1909, p. 39, quotes "Ruge" as saying that Foigny is indebted to Gonneville's discovery of Australia. Herr Günther does not quote work of Ruge, or page. Assuming that "Ruge" means Dr. Sophus Ruge, author of Entdeckungsgeschichte der neuen Welt (in Hamburgische Festschrift zur Erinnerung an die Entdeckung Amerika's, Band I, IJamburg, 1892) and other works, it is strange that this learned person should see resemblances between the accounts of Gonneville and Foigny. Aside from the misfortunes of the return journey just before reaching port, there is little similarity. Even this similarity is much stronger between the Histoire des Sévarambes and Gonneville's account than between Gonneville and Foigny. It is not unlikely that Herr Günther, whose faulty citations have been previously referred to, has misquoted Dr. Ruge. If definite citations were given in Herr Günther's thesis, it would be an easy matter to verify this apparent error. That Foigny knew the story of Gonneville's travels has been pointed out in resuming the $A u$ Lecteur of the Terre australe connue. That he made any use of it is to be doubted. 
Australia as testimony regarding the Congo. Without raising this question at all, it is easy to account for his denying the existence of these creatures in the Congo upon the basis of his usual method of substantiating statements, - the appeal "to the natives."

To return to the adventures of Sadeur, and the war between the Australian "brothers" and the Fondins, Foigny seems to tire of the description both of the pleasures and dangers of life in Australia, for Chapter XIII begins abruptly. J'écris ce qui suit de l'Isle de Madagascar. It is therefore necessary that Sadeur go back in the story of his life and explain the manner of his coming to Madagascar. That the abrupt beginning of this chapter arouses interest in the reader need not be insisted upon. That the atmosphere of the preceding chapter does not lead one to expect a sudden departure must have convinced more than one guileless reader that Sadeur was a real person - albeit a prevaricator. This sudden break in the novel links this imaginary voyage to the accounts of real voyages by the quality common to both of abrupt and inartistic change of setting.

In going back to explain his departure, Sadeur confesses that the Australians are not very easy people to live with. There are too many things of which they do not speak. To excuse himself, Sadeur says,

comme la Nature ne se peut détruire, quelques précautions que je prisse, j'étois toûjours forcé, malgré toutes mes diligences, de donner quelque marque de ce que j'étois -(p. 232).

The immediate cause for his wishing to leave the "brothers" was his trial for misconduct in the war against the Fondins, the barbaric neighbors of the Australians.

Five charges were brought against Sadeur. First, he had not fought as he should, for he had no ears to show as proof of his valor. (The custom of these peace-loving 
Australians demanded a cutting off of ears, and an exhibition of them after the battle.) Second, Sadeur had shown pity on seeing the suffering of the enemy. Third, he had embraced a Fondine. (As the Fondins are like Europeans, Sadeur had not sufficient strength to resist the charm of the first woman he had seen in many years.) Fourth, Sadeur had eaten of the food of the Fondins (this after the delights of the Australian fruit diet!). Lastly, he had asked wicked questions (p. 233).

As a result of this trial, the "brothers" requested Sadeur to eat the fruit of the Balf, and quit this world for good and all. That a man interested enough in life to kiss pretty Fondines should look forward to leaving this world with pleasure is not to be expected. Thus Sadeur made his escape from the community of the over-virtuous "brothers" and left them apparently without regret.

Before considering the manner of this escape, an examination of the abrupt change in the point of view of Sadeur is necessary. These Australians, whose virtues have been extolled, whose civilization has been praised in such glowing words, are now criticized. There is but one slight consistency in these two opposed points of view. Sadeur has admitted throughout the book his inferiority to the wise Suains, and in general to the other members of the community. This was necessary to bring out the inferiority of Europeans with respect to Australians. In the criticism of the Australians, Sadeur still admits that he has faults and that these "brothers" have none. Foigny's lack of art lies in his stressing the point of view that these people are so virtuous as to make boresome, nay dangerous, companions.

There are two reasons why this criticism should be brought into the story. In the first place, Sadeur must have some adequate reason for leaving the delightful land. In the second, no one can take an interest, for 
long, in a perfect State. It is not surprising that Foigny, when he had dwelt on the superiority of the "brothers" for many pages, should have been overcome with weariness. His love of the extraordinary, and his own (and Sadeur's) tendency to seek pleasure in things of the flesh as well as in those of the spirit, makes it only natural that, once the departure from the ideal land is accomplished, the reasons given for leaving should be more than adequate. Foigny seems to overdo the explaining of this departure. That it is inartistic in the extreme; that it greatly impairs the plausibility of the argument in the main part of the book; that it weakens the artistic and philosophical structure of the story, is only too evident.

If, as M. Chinard says, ${ }^{54}$ Foigny $n^{\prime} a$ abouti, malgré tous ses efforts, qu'à nous présenter la peinture d'une société . . . qui n'est autre chose qu'un couvent d'où la religion aurait disparu, it is also true that in the chapter explaining Sadeur's departure we have a keen criticism of the necessary faults and shortcomings of such a society.

The complete lack of unified plan in La Terre australe connue precludes any attempt to generalize about the purpose of the book. In a story so inartistically put together, it would be unwise to say that Foigny had drawn a picture of a perfect convent, only to satirize it in the chapter describing his hero's escape. It is wiser probably to admit that the community of the "brothers" resembles "a convent of philosophers in which there is no religion," and to point out that Foigny is so little an artist that he refutes his own argument by insisting upon the difference between these passionless men and the normal person, his Sadeur. That Foigny, the man, had known both the pleasures of the contemplative life of the cloister, and the imperative call of physical appetites,

${ }^{54} \mathrm{G}$. Chinard, L'Amérique et le rêve exctique, p. 205. 
is reflected in his inartistic mention of both in the same book, and in his defending first one, and then the other.

Sadeur makes his escape from the Austral continent by means of one of the strange birds, the Urgs. Having caught one in a net, and having starved it into submission, he finally tames it, and teaches it to carry him on its back. He begs a few more days of grace of the "brothers," in which to compose his spirit before eating the deathfruit. Having made good use of this respite, he flies away with the story of his adventures, and a small quantity of food. After the bird has grown weary and can no longer bear him, Sadeur floats on the sea for some time thanks to a sort of "life-preserver" belt. He is picked up, finally, in a dense fog, by a French vessel returning to Madagascar from a cruise. If the flying away is fantastic and "medieval," the life-preserver and the French ship are distinctly realistic. It may be said in passing, that to those who know the sea, the account of Sadeur being seen by moonlight and rescued from the sea (in the first part of the story), and the account of his being picked up in a dense fog on the Indian Ocean, is as marvelous as anything in the story, not excepting the Urgs and the bright colored sheep.

After eight days of sailing, Sadeur lands at Tombolo in Madagascar. He retails the accounts of cannibals and their atrocities as told him by the governor.

The passion of Foigny for simple languages comes to the fore again. There arrives from one of the Austral islands un venerable Vieillard \& six Rameurs qui lui servoient aussi de Valets (p 260). Of his conversations with this old man, Sadeur says (p. 261)

Nous convinmes par signes, de prendre certains mots pour expliquer nos pensées; \& j'en formay en une nuit près de deux cens, qu'il comprit facilement. 
The similarity of this incident to the learning of Esperanto by the direct method is evident. Among other interesting things told by the venerable old man (the second character of this type in the story), is that son peuple aymoit plus sa liberté que sa vie (p. 263).

There is a farewell bit of the extraordinary, when Sadeur goes to bid his venerable friend good-bye, before taking passage for Europe. The poor old gentleman is heartbroken. He calls in his own language to two of his six valets. They come and wring his neck, then dash head-first at each other, fracture their skulls, and fall dead. As if this were not convincing evidence of the sincerity of the old man's grief at Sadeur's departure, there follows:

Les quatre autres, bien qu'éloignez firent le même au même tems que les autres: de sorte qu'on les trouva morts tous ensemble, non sans un tres grand étonnement du gouverneur, \& de sa compagnie (p. 264). ${ }^{55}$

The final paragraph of the book purports to have been written by the one who took Sadeur's notes after his death. Part of it reads (p. 267) s'étant embarqué bientôt apres, il n'eut plus le loisir d'écrire les avantures de son retour.

Thus ends the extraordinary novel of adventure and philosophy in Europe, Africa, and Australia. Its hero escapes from four ship-wrecks, and from sudden death at the hands of men, hermaphrodites, and many sorts of strange beasts to bring to Europe the story of a society so perfect that (in spite of occasional excitement in the

${ }_{55}$ This is a clear reflection of many stories of the East Indians The wives and slaves of Hindus are reported by many 17 th century travelers to India to seek death upon the demise of their lord and master. Foigny has adapted this very common report to his purposes. 
way of wars and battles with strange monsters) he himself tired of it. That this first novel of Extraordinary Voyage should be closer to the fantastic novel of adventure than the later Extraordinary Voyages is only natural. In the Histoire des Sévarambes of Vairasse the fantastic is almost entirely lacking and the adventurous element greatly reduced. Foigny's novel stands between the exaggerated accounts of voyages actually made and the more perfect form of philosophical-social-exotic novel - which follows.

\section{Conclusion}

There are two main features in the Terre australe connue: First, the fantastic adventure and the interest in exotic and extraordinary things and people. This is a medium in which is borne the philosophical and social content. Second, the ideal commonwealth, opposed to and compared with the state of society in Europe.

The basis of the first part lies in the novels of adventurers, of travelers, vagabonds and buccaneers, and probably in the accounts of voyages of De Bry, and the engravings illustrating these voyages. Ce.tainly, Foigny knew the Petition of de Quir to the King of Spain.

The basis of the second part is probably to be found in legends and stories of hermaphroditism, in religious heresies, possibly in the ideas of Plato. This part is developed by processes of rationalism.

Foigny rebels against the current ideas of geography (Congo), against current ideas of climate and the influence of the sun's proximity on weather, against accepted natural history in the case of many strange and highly colored animals. In social matters, he rebels against the dominion of man over woman, against anything that limits a man's liberty. In religious matters, he rebels against revealed religion, the authority of the 
Old Testament, the missionary spirit of the times, and against the constant agitation of religious problems and discussion of them.

Rationalism is the characteristic of the entire book, as far as the thought contained in it is concerned.

The effect of the book as a whole is broken, disconnected, and (but for the fact that it all concerns Sadeur) almost incoherent. This is the result of Foigny's failure to weld artistically the adventurous and exotic elements of the story with the philosophical and social elements. The fact that Foigny used, to substantiate his "discoveries" of remarkable springs, animals and plants, the same rationalistic methods which he used to substantiate his social and religious assumptions serves in one sense to link the adventures with the theories. That this does not serve to link them artistically is only another way of saying that the intensely logical mind is seldom combined with the creative artistic mind. 


\section{CHAPTER V}

L'HISTOIRE DES SEVARAMBES OF

DENIS VAIRASSE D'ALAIS

1. Publication.

2. Authorship.

3. Life of Vairasse.

4. The Avis au lecteur.

5. The Voyage to the Austral Land.

6. The Austral Civilization.

7. The Journey to Sevarinde.

8. History of the Sevarambian Kings.

9. Government.

10. Education and Marriage.

11. Customs.

12. Laws.

13. Religion.

14. Laws and Prayers of Sevarias.

15. Language.

16. Omigas the Imposter.

17. Digressions.

18. Inventions.

19. The Return to Europe.

20. Conclusion.

\section{Publication}

In 1677 there appeared at Paris a very important novel of Extraordinary Voyage of the 17th Century, and in many ways the most remarkable novel of this type. The History of the Sevarites or Sevarambi, by the same author but published in English, had appeared at London two years earlier. The first title in French is: 
Histoire des Sévarambes, peuples qui habitent une partie du troisième continent ordinairement appelé Terre Australe, contenant un compte exact du gouvernement, des mœurs, de la religion, et du langage de cette nation, jusques aujourd'hui inconnue aux peuples de l'Europe. Trad. de l'anglois. ${ }^{1}$

\section{Partie I appeared at Paris in 1677, Partie II, in 1678 and 1679.}

The fact that this remarkable book was reprinted at Brussels in 1682, at Amsterdam in the same year and in 1702, and again at Amsterdam in 1716, all these editions being, in French, is ample proof of its popularity among French readers at the time it appeared. Translations into Dutch in 1683, German in 1689 and 1714, and Italian in 1728 are mentioned by Prosper Marchand. ${ }^{2}$ Another early German edition, without date, is mentioned by Max Günther. ${ }^{3}$

The editor of the large collection, Bibliothèque des voyages imaginaires, says ${ }^{4}$ that the Histoire des Sévarambes tient un rang distingue parmi les voyages imaginaires. That Bayle mentions the Histoire des Sévarambes in a note to his article Sadeur ${ }^{5}$ and that Morhof finds the novel worthy of censure and condemnation in his Polyhistor literarius philosophicus et practicus ${ }^{6}$ is also interest-

${ }_{1}$ Only the first part of the novel had appeared in English at the time. For complete treatment of the English version see Appendix.

${ }^{2}$ Dictionnaire historique, Paris, 1758-1759, Article Allais.

'Entstehungsgeschichte von Defoe's "Robinson Crusoe", Greifswald, 1909, pp. 41-42.

4 Amsterdam, 1787-1789, vol. 5, Préface.

- Dictionnaire critique, ed. 1697.

6 Morhof attacks the author of the Sévarambes, unknown to him, as an atheist, but admits that the book is well constructed, and is insidious, being so well written that it is liable to convince those who are not cautious. Morhof believed it to have been written first in English. The Latin of this criticism reads in part:

Pertinere \& ad hanc Atheorum \& Naturalistarum tribum videtur, 
ing. According to Marchand's Dictionnaire, previously cited, the book was attributed not only to Isaac Vossius, but to Leibnitz, to an Englishman named Sidney, to Delon, to Devese and to many others. That the Histoire des Sévarambes attracted enough attention to be attributed to so many authors, and some of them so well known, is curious in the light of later events. After the Dictionnaire of Marchand (1758) and excepting $L a$ France Protestante of $\mathrm{Haag}^{7}{ }^{7}$ no serious notice was taken of this book as an important philosophic novel, until its rediscovery by $\mathrm{M}$. Lichtenberger, published in $L e$ Socialisme au xviii siècle, in 1895.

\section{AUTHORSHIP}

There can be no doubt that the Histoire des Sévarambes is the work of Denis Vairasse d'Alais. The articles mentioned in Marchand's Dictionnaire and in Haag's La France Protestante leave no doubt on this point. A further proof, heretofore unmentioned, is the signature "D. V." of the To the Reader of the English version (First Part, London 1675). In Marchand's Dictionnaire, ${ }^{\mathbf{8}}$ occurs the following:

cependant lors que d'Allais la mit au jour, il cachoit si peu qu'il l'eut composée, qu'il ne faisoit aucune difficulté de la donner comme Auteur à ses Amis \& à ses Disciples; \& personne n'en doutoit aucunement alors.

quisquis est, Autor libri, qui primum Anglicâ, hinc Gallicâ, postremum Belgicâ linguâ prodiit, de populis terrae australis incognitae, quos Severambes nominat. . . Elegantissimè confictus est liber, eaque specie, ut primâ fronte incautis imponat. . . . Ceterum ille liber doctus est, magnâ curâ scriptus. (Polyhistor, De libris damnatis, Cap. viii, p. 74. Ed. Lübeck, 1714.)

7 Paris, 1859 , t. x, p. 456, Article Veirasse.

8 p. 12 , Note $B$. 
The title quoted by the Journa' des Sçavans ${ }^{2}$ includes the words chez l'Auteur, which would prove that Denis Vairasse (known at this time as Allais or d'Alais) did not conceal his authorship of the novel at the time it first appeared..$^{10}$

\section{Life of Vairasse}

The date of Vairasse's birth is not known. Marchand says of him that at sixteen, he took part in the Piedmont campaign. After leaving the army, Vairasse took up the study of law, and received the degree of Doctor of Law some few years later. He did not remain long in France however. Having gone to England, he became involved in political intrigue there, and was banished from the country and returned to France. The year 1672 finds him in the French Army in the Flanders campaign, although he was a Protestant. Unable to obtain advancement because of his faith, or perhaps disgusted with military life, Vairasse returned to Paris and gave private lessons in English and in French. During the winters he was accustomed to give lectures on history and on geography. His gift of speech and keen intellect attracted to these lectures many people, some of them of high standing. He had many friends among the Jansenists in Paris, according to Marchand, although he is not known to have renounced his belief in Protestantism, even after the Revocation of the Edict of Nantes.

It is likely that Denis Vairasse used the name d'Alais because he came from the Protestant stronghold Alais, chiefly remembered to-day by Richelieu's Edit de grâce of 1629. Marchand says that he is reported by some to have been related to the Baron d'Allais, autrefois Com-

- Year 1678, p. 87.

${ }^{10}$ L. Moreri, Grand Dictionnaire historique (ed. 1732) shows knowledge of the author "Denys Vairas" in Article Sevarambes. 
mandant des Armées du Roi, but that there is no proof of this report. Of Denis Vairasse's personal appearance, little is known. Marchand says,

sa taille n'étoit pas des plus régulières \& son visage avoit quelque chose de fort particulier ... il parloit très agréablement.

Besides the Histoire des Sévarambes, Vairasse published two other books, both grammatical works. One, a Grammaire méthodique... de la langue françoise, Paris, $1682^{11}$ is reviewed in very flattering fashion by the Journal des Sçavans, ${ }^{12}$ being characterized as the first complete treatise on the subject. Classification of sounds according to phonetic groups, and methodical arrangement are characteristics of the book. The other, $A$ short and methodical introduction to the French tongue, Paris, 1683, is the same work translated into English for the use of English-speaking people in learning French.

It will be found that the campaigns of Vairasse, his travels, his interest in geography, and his studies in grammar and in law, are all reflected in the Histoire des Sévarambes. The philosophic and religious opinions of Vairasse, not recorded by his biographers, form the chief interest of his imaginary voyage written as a medium wherein to convey these ideas.

The date of the death of Denis Vairasse is not known.

\section{The Avis au Lecteur. (Historre des}

SÉVARAMBES)

Perhaps the most interesting testimony in the Article Allais of Marchand's Dictionnaire is that relating to the reception given the Histoire des Sévarambes at the time it was published. He points out that this novel was

11 For complete title, see Bibliography.

12 Year 1682, pp. 130-131. 
generally accepted as a true story, or rather as a true story elaborated by an ingenious editor. The testimony of Morhof as to the plausibility of the story has already been cited. The review of the Second Part of the Histoire des Sévarambes, which appeared in the Journal des Sçavans in 1678 is amusing inasmuch as it takes the middle ground, and hesitates to label the novel either as an account of a real voyage, or as a work of imagination. According to this review: ${ }^{13}$

Les uns l'ont regardé comme une belle idée, \& les autres ont cru de bonne foy tout ce qui y est rapporté sur la découverte des Sévarambes, d'autant plus que suivant le témoignage de plusieurs personnes dignes de foy, tout ce qu'on y lit d'un Navire de Hollande... qui sert de fondement à tout le reste se trouve veritable. Quoyqu'il en soit, le dessein de cette Histoire n'est pas mal conceu (p. 87).

Ceux qui envisagent cette Histoire comme veritable, y trouveront la description ... etc. (p. 89).

Notwithstanding the somewhat over-perfect land of the Sévarambes, there is in the first part of the novel such a wealth of material detail and circumstantial evidence that belief is almost compelled. The burden of "proof" that this is a real and not an imaginary voyage is borne by the Avis au lecteur. To prove the authenticity of the story Vairasse uses a method that is at once subtle and convincing. ${ }^{14}$

13 Year 1678.

14 In some later editions, the Avis au lecteur has been considerably cut down, and the strength of the argument for authenticity of the story greatly weakened. References in the present study are to the edition of Etienne Roger, Amsterdam, 1702, which is complete and quite commonly found. The edition given in the Bibliotheque des voyages imaginaires, Amsterdam, 1787, cited by MM. Lichtenberger and Chinard, is very much reduced in volume. For complete titles of editions see Bibliography. 
The $A u$ lecteur begins with a careful distinction between real voyages such as the story which is to follow, and imaginative works of the type of the Republic of Plato, the Utopia of More, and the Nova Atlantis of Bacon. The editor hopes that the Histoire des Sévarambes will not be confused with such books.

A second realistic method is that of lamenting, after the fashion so much in vogue among explorers of the time: Il seroit à souhaiter qu'une heureuse paix donnât aux princes le loisir de s'occuper de pareilles découvertes (Au lecteur, p. 3).

The fact that Columbus did not gain belief in his theory of land to the West until he had tried his experiment is recalled to the reader. Then, banking on the force of his own convincing style, the editor (really Vairasse the author) says of the story which is to follow, Elle est écrite d'une manière si simple que personne, à ce que j'espère, ne doutera de la vérité de ce qu'elle contient (p. 5).

Next comes the history of the publication of the story. Captain Siden, whose personal experiences in Australia and elsewhere constitute the novel, died as the result of wounds received just before reaching Holland after a protracted absence. ${ }^{15}$ Before dying, Captain Siden turned over the memoirs of his adventurous life to a traveling companion. This latter, unable to read the memoirs, which had been written in several languages, including French, Provençal and Italian, turned them over to the writer of the Avis au lecteur.

Witnesses are plenty to assure the author of the Avis au lecteur that Captain Siden did, about the date stated in his memoirs, leave the River Texel on a vessel named

${ }_{15}$ See note 53, Chapter IV. Similarity to the story of Capt. Gonneville, attacked when almost in port after his journey to Brazil (1503-1504), is evident. 
the Dragon d'or, loaded for Batavia, and that no word was heard of him in Holland thereafter. The author of the $A u$ lecteur ascertains from the Counsel of the Dutch East India Company that the vessel was wrecked; that a pinnace, manned by some of the survivors, did reach Batavia, and that an unsuccessful attempt was made to go to the rescue of the unfortunates who had been left stranded on the coast of Australia. A long letter from a man named Skinner is reproduced verbatim to prove that the pinnace contained a certain sailor named Prince. Other testimony is adduced, names, dates and places being cited.

Naturally; when the story of Captain Siden's shipwreck comes, in the body of the book, the name of the sailor, Prince, is mentioned, and the guileless reader is convinced of the truth of the whole story. This became a hackneyed method of substantiating desert island stories in the eighteenth and nineteenth centuries. In 1675, when this novel of Vairasse was published in England, and in 1677, when it was first published in French, this method of substantiating novels of adventure was distinctly new. It was as new as the story of the palisaded camp on a deserted coast, which will be found in this story but which is generally associated with the Robinson Crusoe of forty years later.

\section{The Voyage to the Austral Land}

The first chapter of Captain Siden's life begins with an account of his youth. Except for reading accounts of voyages, he has little in the way of adventure in his life until he is fifteen! At this age, he goes to Italy in the Army, and later to Catalonia. After giving up "l'épée pour la robe," he studies law, and in four or five years is a Doctor in Law. His mother's death leaves 
him free to travel soon afterwards, and he visits most of Europe. ${ }^{16}$

In April 1655 he embarks for the East Indies on a vessel named the Dragon d'or, in company with a young man named Van-de-Nuits. Until after passing the equator the story is very brief.

Il est vrai que nous vîmes plusieurs monstres Marins, des poissons volans, de nouvelles constellations, \& d'autres choses de cette nature. Mais parce qu'elles sont ordinaires \& qu'elles ont été décrites, \& que depuis plusieurs années elles ont perdu la grace de la nouveauté, je ne crois pas en devoir parler, ne voulant ... lasser la patience du Lecteur \& la mienne (pp. 25-26).

This is very different from the method of Foigny, whose account fairly bristles with novelties difficult of belief. It is, however, curiously like an account of a real voyage from which it can be shown Vairasse took entire the sea-voyage, shipwreck, and some later incidents of the Histoire des Sévarambes. In La Terre Australe descouverte par le Capitaine Pelsart, qui y fait naufrage ${ }^{17}$ occurs the following sentence, which is interesting in the light of much more definite similarities in the later parts of the two stories:

Ie passeray sous silence le Iournal de sa Nauigation jusqu'au Cap de Bonne Esperance, de peur d'ennuyer le Lecteur par le recit d'vne chose aussi connuë que l'est cette route.

In both accounts, the vessel leaves the Texel, bound for Batavia. In both accounts the vessel runs through fog after passing the Cape of Good Hope. In both accounts

${ }^{16}$ This is a reflection of the life of Vairasse, who had much the same experience.

${ }_{17}$ Relations de divers voyages curieux, qui n'ont pas esté publiées, par les soins de Melchisedec Thevenot, Paris, 1663-1672. Vol. 1, Première Partie. This collection was published in a second edition in 1696, Paris, chez Thomas Moette. 
there is a storm, and after the storm a calm. During this comparatively good weather, the vessel in each story strikes a reef, from which it is impossible to move it. In both cases there are low and sandy islands near at hand, and in both a long and ineffectual attempt is made to find fresh water. Holes are dug, but only brackish water is obtained In both cases, the master of the ship is one of those who attempt to reach Batavia in a hastily constructed pinnace, made from the wreck.

Naturally, when the men are selected to man the pinnace, Vairasse's story mentions the sailor Prince, previously referred to in discussing the $A u$ lecteur. In the Histoire des Sévarambes (p. 37) Le sort tomba sur le Maitre même, sur un matelot appellé Prince, \& sur six autres, dont j'ay oublié les noms. In Pelsart's story, from which Vairasse took his realistic introduction to the land of Sevarias, there is no mention of a sailor named Prince.

In Vairasse's novel, Captain Siden is elected General of those remaining on the coast, by a unanimous vote. He apportions the labor to be done, the guards to be set, the provisions to be made, and sets off with thirty others to hunt for water, after leaving the women in a stockade. Finding a stream flowing into the ocean, he moves his company there, founds a permanent camp, divides the labor of hunting, fishing, and guard duty anew, plants peas, and sets up a permanent colony. At about this time, some of the hunters find and kill a tiger. Frightened at the presence of wild animals in the region, Captain Siden has a complete and permanent stockade of logs built about the camp (p. 62). ${ }^{18}$

All exploring expeditions having failed to discover any inhabitants, the company settles down to wait for relief from Batavia. There is an incident of two young men 18 The similarity to Defoe's story is evident. 
of the company coming to blows over the favors of one of the seventy-odd women who were part of the ship's passengers. The woman in question and a young man are wounded by a sword-thrust. This brings about a decision on the part of Captain Siden, who governs the company with an iron hand. He says (p. 68):

Cet accident donna lieu à de nouvelles Loix; nous considerâmes que tant que nous aurions des femmes parmy nous, elles seroient cause de quelques troubles, si nous n'y mettions ordre de bonne heure, \& ne permittions à nos hommes de s'en servir d'une maniere reglée. Mais le mal étoit que n'ayant que soixante \& quatorze Femmes, \& étant plus de trois cens hommes, il n'étoit pas possible de donner une Femme à chacun. Nous consultâmes longtemps pour trouver un expédient raisonnable; enfin il fut resolu, que chaque principal Officier auroit une Femme pour lui, \& que chacun d'eux en choisiroit une selon son rang. Nous distribuâmes les autres en diverses classes selon le rang des personnes.

The more explicit part of the rules laid down by Captain Siden can well be spared in this short summary. The author's opinion of the wisdom of this division of women, he supports with the following incident (p. 69):

Nous separâmes du reste les hommes qui avoient passé cinquante ans, \& quatre Femmes qui alloient trouver leurs maris à Batavia, \& qui se piquerent de constance... Mais quand elles eurent vu que...le secours qu'on attendoit de Batavia ne venoit pas, elles parurent... melancoliques, \& se repentirent... nous fumes obligez de leur donner des maris comme aux autres.

The conclusion of this incident is interesting, as it shows the philosophic-exotic interest of Vairasse in the question (p. 69).

Aussi la Poligamie des femmes a été souvent pratiquée, \& elle l'est encore aujourd'huy parmy quelques Nations: mais 
je n'ay pas encore lû que celle de plusieurs maris ait jamais été en usage.

There is conclusive enough evidence, however, that Vairasse had read of it being practiced, for the following account of the actions of one "Ierosme Cornelis" occurs in the story of Pelsart previously referred to:

Il devoit commander en l'absence de Pelsart, \& crut... qu'il luy seroit aisé de se rendre maistre de ce qui estoit resté du débris ... se choisit des gardes qu'il fit habiller d'écarlatte ...\& comme si les femmes eussent esté vne partie du butin, en prend vne pour luy, donna vne des filles du Ministre à vn des principaux de sa trouppe, \& abandonna à l'usage public les trois autres; il fit mesme quelques Reglemens pour la maniere dont elles deuoient servir.

Apres ces horribles executions, il se fait élire Capitaine general par vn acte qu'il fit signer à tous ceux de son party.

In the story according to Pelsart, there is a just retribution for the crimes of Cornelis. Help is obtained at Batavia. The doughty Pelsart returns on a Dutch cruiser and finds the colony. The end of Cornelis and his accomplices is described in a sentence which is an admirable example of the pithy and succinct style of the accounts of real voyages:

Le vingt-huitième, ... la pluralité des voix alla à les juger \& faire executer sur le lieu, ce qu'ils firent.

The incorrigible Captain Siden, on the contrary, sums up the evidence of the case in a physiological conclusion that is strikingly modern (p. 69):

L'experience nous fit voir en cette rencontre que la pluralité des hommes est contraire à la génération, car peu de celles qui avoient plusieurs maris devinrent grosses; \& au contraire, presque toutes celles qui n'en avoient qu'un, le furent. 
Since the copying of detail and incident is so marked in the Histoire des Sévarambes, it is interesting to note a further similarity of names of characters between the two stories. In Vairasse's novel, one man whose name appears frequently in the first part of the story is "de Haës." DeHaës goes exploring and returns telling of his journey (pp. 45, 53, 55). He says on his return qu'il avoit marché vingt milles le premier jour (p. 55). In the Pelsart story is a man named Vveybe-Hays who went looking for water on the mainland, and found it after hunting for twenty days, instead of walking twenty miles.

In the Histoire des Sévarambes, the close personal friend of Captain Siden, with whom he sails from Holland and who is with him throughout the Australian part of the story, is named Van-de-Nuits. On an old map, bound with the Relation of Pelsart in Thévenot's collection, is the inscription:

Landt van P. Nü̈ts; opgedaan met het gulden zeepardt van Middelburgh 16 Jan. Anno 1627.

That "van" is a preposition, and not part of the name "P. Nuÿts" makes little difference.

Naturally, if there were nothing to indicate the imitation of Pelsart's account except these names, it would be futile to mention them. Having established, however, indebtedness of Vairasse to this account of a real voyage, the similarity of names is interesting. ${ }^{19}$

It may be remarked in passing that Captain "Siden" is merely "Denis" in an anagram as "Sevarias" the great law-giver of the Sevarambian civilization which follows is "Vairasse" transposed."

19 The indebtedness of Vairasse to Thévenot's collection has not been mentioned previously.

${ }^{20} \mathrm{M}$. Lanson has pointed out these two anagrams, Reoue des Cours et Conf., 1908-1909. 


\section{The Austral Civilization}

When there is no further interest in the colony of shipwrecked people, which is functioning admirably under the regulations of Captain Siden, the natives of Australia are introduced. Having gone on an exploring expedition far into the interior, some of the shipwrecked company return to the stockaded camp, accompanied by representatives of the Australian government. Concerning a courteous, not to say worldly representative of the Australians, one is astonished to read (p. 78):

Il nous receut avec beaucoup de douceur \& de gravité, \& levant la main droite vers le Ciel; il nous dit en assez bon Hollandois: Le Dieu Eternel vous bénisse, le Soleil son grand Ministre \& notre Roi glorieux luise doucement sur vous, \& cette Terre nôtre Patrie vous soit heureuse \& fortunée.

If the natives of Bacon's New Atlantis greeted strangers in Spanish, the Australians of Vairasse, not to be outdone, are proficient in Dutch. They do not explain their proficiency in European languages until much later in the story. After inspecting the camp, the noble stranger retires to a tent, leaving one of Siden's men, Maurice, to recount what has happened, and how he came to find the Australians. The story of his cordial reception among the Australians is cheerful news to the little colony. It appears that Maurice and his companions, having followed a river some miles inland, came upon some men, in boats. These natives conducted them to a good sized city, where they were well received, given new clothes, bathed, and led before the local governor and his guard of soldiers, who had muskets and blue uniforms. The shipwrecked men were provided with every necessity and comfort, including female slaves.

There are two significant parts of this report of the explorer Maurice to Captain Siden. The rest is merely 
a long description of rather commonplace things such as costumes, receptions, and the topography of the country. The first of these important ideas is stated in the following terms (p. 94):

Ces peuples font ordinairement de bonne garde sur leurs frontiéres parcequ'ils craignent que les étrangers ne viennent corrompre, par leur mauvais exemple, leur innocence \& leur tranquillité, en introduisant leurs vices parmi eux.

That this recalls the precautions of the Nova Atlantis when Bacon's travelers are received, is obvious. It likewise recalls the hostility of Foigny's Australians to the degenerating influence of the demi-hommes from Europe. There is an extension of this idea in the Histoire des Sévarambes, however. It is the people of Sporounde, an outlying province, that the explorers from Europe have come upon. Of the people of Sevarinde itself, the ideal province of the ideal land, the Europeans have no experience until later. In Sevarinde no imperfect people are tolerated, for (pp. 95-96)

ceux de Sevarinde y envoient [à Sporounde] tous les gens contrefaits qui naissent parmy eux, n'en voulant point souffir de semblables dans leur Ville.

Whereas the Australians of Sadeur killed at birth any one-sex monsters, the more humane Sevarambians banish all the halt, lame, and blind to Sporounde.21 The similarity of this procedure with that advocated by earlier writers on eugenics is another proof of the sources of Vairasse. ${ }^{22}$ This is (as in the case of polyandry among

21 In the English version of 1675, deformity of body is an inevitable accompaniment of moral obliquity. The people of Sporounde are all twisted in body because they are imperfect morally. (For more full treatment of English version, see Appendix.)

22 Plato and Campanella had both suggested control of society for the physical improvement of the race. Vairasse, through his 
the shipwrecked company) not only theory but practical demonstration.

The second matter of importance in Maurice's account of the exploring expedition is the Sevarambian philosophy of temperance, which appears twice within a very few pages. The Governor of Sporounde, speaking to the strangers he is receiving, ends his oration with Je vous exhorte à la modération \& à l'honnêteté (p. 95). The guide Sermodas, who speaks Dutch and is a person of some importance, elaborates on this philosophy after presenting each visitor with a female slave. The fact that these sea-faring men, who have just been presented with female slaves, might have been somewhat inattentive to the discourse is not to be thought of, for we are now in the interior of the Ideal Land, and the philosophy of the author is not to be interfered with by considerations of realism. The importance of Sermodas' speech in setting forth the ideas of Vairasse is such as to warrant its reproduction here almost entire:

Toutes les Nations du monde ont leurs coutumes: Il y en a qui sont naturellement mauvaises parcequ'elle sont opposées à la raison. Il y en a d'autres qui sont indifférentes, \& qui ne semblent bonnes ou mauvaises que selon l'opinion \& le préjugé des hommes qui les pratiquent; mais il y en a aussi qui sont fondées en raison, \& qui sont véritablement bonnes d'ellesmêmes, pourveu qu'on les considere sans préoccupation. Les nôtres sont presque toutes de ce dernier genre, \& à peine en avons-nous aucune qui ne soit établie sur la raison. Vous n'ignorez pas sans doute que l'usage modéré des choses que la Nature a destinées pour servir aux créatures vivantes, ne soit bon de soi, \& qu'il n'y a que l'abus qu'on en fait qui soit effectivement mauvais. Parmy toutes ces choses il y en a trois principales: La premiére regarde la conservation de chaque particulier: La imaginary but carefully authenticated Captain Siden, reports having found this theory put into practice with good results. It is the realism of Vairasse that makes his novel dangerous. 
seconde, l'entretien dans un état heureux: Et la troisiéme enfin, a pour but l'accroissement ou la multiplication de chaque espèce (pp. 97-98).

Further, those things which the Sevarambians consider as necessary for the conservation and proper condition of men are:

la santé du corps, la tranquillité de l'esprit, la liberté, la bonne éducation, la pratique de la vertu, la société des honnêtes gens, les bonnes viandes, les vêtements, \& les maisons commodes (p. 99).

These blessings: rendent la vie heureuse, pourveu qu'on en use sobrement, \& qu'on n'y attache point son cceur (p. 99).

For the third consideration, the increasing of the species, Nature (not God, but Nature) has caused all animals to exist either as male or female:

Mais pour rendre l'état de chaque animal encore plus heureux, \& pour venir plus facilement à bout de son dessein, elle a voulu attacher à cette union un plaisir, que nous appellons amour. Cet amour est le lien \& le conservateur de toutes choses, \& lorsqu'il est réglé par la droite raison, il ne produit que de bons effets, parcequ'il ne propose que de bonnes fins (p. 100).

In quoting from the sentiments of Sevarias notre grand \& illustre législateur, Sermodas does mention les desseins de Dieu \& de la Nature, pour la conservation du genre humain.23 In accordance with these plans of God and Nature, Sevarias had marriage made compulsory for all attaining a certain age, and cohabitation with slaves optional with travelers.

That moderation and not abstinence is the natural and God-willed path for man to follow, is put in the

23 This theory is as old as St. Thomas Aquinas, and is found again in Campanella's Civitas Solis. 
form of a direct challenge to European ideas. With the Sevarambians it is forbidden de regarder comme une chose criminelle ce qui sert à la conservation de l'espèce (p. 100). It is also forbidden que les excès troublent la modération qui doit se trouver dans l'usage de tous ces plaisirs. Continuing, there follows (p. 101) the challenge to Europe:

C'est pour cette raison que nous ne souffrons pas que personne soit ici sans femmes, vous voyez aussi qu'on vous en a amené autant que vous êtes ici d'hommes... Je sçai bien que cette coûtume seroit condamné en Europe, où l'on ne considere pas assez que la vertu se trouve dans l'usage honnête de l'amour, $\&$ non pas à y renoncer entiérement; mais aussi nous ne yoyons parmy nous aucun de ces crimes abominables qui déshonorent vôtre paìs.

As if this were not sufficient condemnation of Europe, the party of Maurice is subjected to a thorough physical examination before being allowed to associate with the female slayes. It is from the doctors who perform this rigid examination that the strangers learn how the Sevarambians get their information about Europe. These doctors have traveled extensively in Europe and Asia, and are only two of many who have been sent out by the Sevarambians to glean information and new discoveries from foreign lands, as well as to devise means of keeping the scourges of other countries from jeopardizing the perfect state founded by Sevarias.

Foigny pleaded for a hearing in Europe for the enlightened people of Australia. Vairasse describes the methods of the Australians in keeping their civilization perfect in spite of Europe. The sanitary inspection of the Nova Atlantis is a mere formality. The criticism indulged in by Vairasse in this searching physical examination is subtle but caustic. 
The story of Maurice, just analysed, is as striking as anything in the book, although much social, religious, and ethical material comes later in the story. The insistence upon this conception, Nature, ${ }^{24}$ in the report of Maurice is almost startling, if it be considered that the printing of the Sévarambes was contemporaneous with the appearance of Phèdre and of La Princesse de Clèves. God and Nature are joined merely for form's sake. In general, Nature is alone referred to in Maurice's account of the speeches made to him by the Sevarambians. This is not the Nature of the out-doors, of the far-off and solitary places of the earth, which comes later in the Voyages et aventures de François Leguat (1708) and which is generally associated with the greater genius of Defoe, Rousseau, and Bernardin de Saint-Pierre. Neither is it quite the Nature of a formal and beatific sort found in Foigny's Terre australe connue, which is, as M. Chinard has suggested ${ }^{25}$ a reflection in later days of la nostalgie de l'Eden des siècles de foi.

Nature, in the exposition of Vairasse's ideas through the words of Sermodas, is not a personified being to be worshiped, loved, and celebrated in rime. It is rather a rationalistic system of things, a materialistic system, by virtue of which man and the world in which he lives can be interpreted in terms that are capable of formulation and definition. "Conservation of the species" in 1677 reminds the modern reader perhaps of Huxley, Spencer, and others of the Darwinian school, rather than of St. Thomas Aquinas. But the same term, used to excuse the expression nous ne souffrons pas que personne soit ici sans femmes, sounds remarkably like the voice of

${ }^{24}$ Campanella, being sincerely religious, bases his conclusions in the Civitas Solis on the will of God. With Vairasse it is Nature rather than God which acts "for the good of the race."

${ }^{25}$ L'A mérique et le rêve exotique, p. 205. 
profigate Rousseau pleading with the mothers of France to nurse their own infants. (It will be found later that Sevarambian mothers are obliged by law to do this.) The term Nature to an epicurean logician like Vairasse serves as a weapon against tradition, customs, revealed religion, social prejudice and precedent. It is, moreover, a shield and an excuse (when there is need) from whose shelter it is convenient to expound new ideas, particularly sex-ideas.

The wide divergence between Foigny and Vairasse is nowhere more apparent than in the treatment of women by these two men. Foigny, the defrocked monk and renegade Protestant chorister, never became emancipated from the $\sin$ idea. He laments the lot of woman in European civilization, and shows a definite feministic point of view in the Terre australe connue. The single sentence of Vairasse, nous ne souffrons pas que personne soit ici sans femmes (p. 101) suffices to indicate his point of view. His taking up the distribution of women by Cornelis, in Pelsart's harrowing story of shipwreck, and his making of it a defensible act, can be taken as another index of his "experimental" point of view in these matters. Compulsory marriage and community of women are concomitant phenomena of social revolution based on materialistic philosophy. Strangely enough the inclusion of women in armies as fighters goes hand in hand with these same phenomena of revolution, even as in the army of the Sevarambians there are women.

To return to Maurice's story, it will be remembered that the shipwrecked sailors and their female slaves were in the same room, listening to the philosophy of moderation as expounded by Sermodas on page 97 of the novel. To those who read the Histoire des Sévarambes for the sake of the story, it must have been a relief to find (p. 103) that the last of the philosophers se retirèrent, \& nous 
nous consultâmes de la manière dont nous choisirions nos femmes. Strangely enough, after so long a time in which to compare the merits of the various slaves, the division was made sans querelle \& sans dispute (p. 103). A sad commentary on the willingness of human beings to display that moderation which is the greatest wisdom is found in the description which includes the words: . . des chambres où ils avoient été enfermés toute la nuit, pour empêcher le désordre \& l'échange qu'on auroit pu faire; ce qui n'étoit pas permis (p. 104).

\section{The Journey to Sevarinde}

A few days after the return of Maurice and the Australian representatives, the party of Captain Siden begins its journey to Sevarinde. Arrived at Sporounde, the capital of the nearest province, a new division of women takes place. Each woman of the shipwrecked party has the right to retain the man whom she holds responsible for her pregnancy. The other men are supplied with female slaves.

The party is then received at the temple by the Governor and his entourage of senators. A marriage ceremony takes place at the temple. It is as perfectly systematized and executed as anything reported of the Sévarambes by Captain Siden. Two files, 'one of young women of marriageable age, one of unmarried young men, are lined up on opposite sides of the temple. Each young woman in turn designates the young man of her choice. Each young man has the power of acceptance or of veto. A few women are left over, after the pairing off. Of these, some wait for another opportunity, which will come after a set period of time. The remainder, having been thrice refused in public, are permitted to request a senator or other public official to accept them as plural 
wives. The request is made in three cases, and les trois Senateurs descendirent incontinent, \& les prenant par la main, les menerent d' l'Autel (p. 118). Thus the young women, who in Europe would have remained spinsters, are saved from this lonely fate. The authorized polygamy in the case of state officials serves to do away with the evils of celibacy. That anything is preferable to celibacy seems to have been the judgment of Vairasse.

The temple of the city of Sporounde resembles the other temples of the land. The deity of these people is triple in its manifestations. There are three features of the temple. First, there is a large globe of glass, which represents the sun (for the Sévarambes are sun-worshippers). Second, there is an allegorical figure of a many-breasted woman, representing the fertile native land. Third, there is a large black curtain drawn across the altar, at the back, representing the unknowable God. The resemblance of the image of the sun to the golden sun in the temple of the Incas, together with the similarity of the Pachacamac, or incomprehensible god of the Incas to the unknowable god of the Sevarambians is too evident to be insisted upon. This similarity has been mentioned by Marchand. ${ }^{26}$

The third member of the Sevarambian trinity is however of Asiatic origin. In the Voyages en Tartarie of Pierre Bergeron ${ }^{27}$ occurs the following description of the idols of the Tartars:

cependant ils ne laissent pas d'auoir des idoles de feutre faites. à la semblance d'hommes, \& les posent de part \& d'autre des portes de leurs logis; $\&$ au dessous y a ie ne sçay quoy de mesme estofe, en forme de mammelles, \& croyent que c'est ce qui garde leurs troupeaux, \& qui leur donne du laict, \& des petits.

${ }^{26}$ Dictionnaire, Article Veirasse.

27 Paris, 1634, Voyage de Carpin, ch. 3, pp. 323-324. 
A marginal note by Bergeron reads, $M$. Pole appelle Natigat ceste sorte de Dieu là, l. 1. c. 46 \& l. 2. c. 16 c'est le Dieu des choses terrestres. The same god is mentioned in the Traicté des Tartares of Pierre Bergeron. ${ }^{28}$

In the Voyages en Tartarie, a few pages after the quotation above ${ }^{29}$ occurs the following which is curiously like the speech of Sermodas previously quoted, regarding traditions of people and their influence in conceptions of right and wrong:

Et bien qu'ils n'ayent aucune loy pour ce qui est de la justice, ou pour se garder du peché; ils ont toutefois ie ne sçay quelles traditions de choses qu'ils tiennent pour peché, selon qu'euxmesmes \& leurs ancestres se sont imaginez.

Further reference will be had to the Voyages en Tartarie in dealing with the government, laws and property conceptions of the Sevarambians.

That this trinity of the Severambians should be two thirds South American and one third Asiatic is curious. Were it not for later and more definite proof of Vairasse's indebtedness to the Commentaire royal ou l'Histoire des Yncas, it might be supposed that the sun-worship mentioned here was taken from the Persian sun-worshipers.

After several ceremonies of less importance, the company start on their journey to the capital. On stopping at one city, Captain Siden sees fourteen prisoners being led out to punishment. Of these there were six hommes ... condamnés d̀ dix ans de punition, quelques uns pour avoir tué, \& d'autres pour avoir commis adultère (p. 126). There are also two women convicted of adultery, who devoient être punies durant sept ans pour satisfaire aux Lois; ensuite elles devoient souffrir aussi long tems qu'il

${ }^{28}$ Paris, 1634, p. 69. This Traicté is a sort of compendium of information referring to Tartary, composed by Bergeron.

29 p. 327. 
plairoit à leurs maris (p. 126). Unmarried persons of both sexes, convicted of adultery, are punished and then made to marry. Vairasse's point of view with regard to women is again brought out in these sentences.

One curiously inartistic incident is recounted here. A long description of one unfaithful wife is given. Before her punishment takes place, her repentant husband rushes on the scene, to take the lashes intended for his wife. He speaks for more than two duodecimo pages, and is followed in oratory by his repentant wife, who speaks for another full page. In her speech are such gems of style as:

Cessez, cessez de blesser mon cœur par les témoignages d'une bonté \& d'une générosité sans égale (p. 132).

Captain Siden assures the reader that this interview arrachoit les larmes des yeux de tous les assistants (p. 32), but this same tender-hearted crowd belabors the prisoners who are led past after the punishment, si rudement que le sang couloit de leurs playes (p. 132).

This Sevarambian crowd seems to be a strange mixture of précieux and American Indians. They take equal pleasure in weeping over sentiment and "passing prisoners through the lines."

Siden's party now proceeds by boat, thanks to well built canals, which,

on ne sçauroit faire en Europe pour cinquante millions de livres, \& neanmoins l'industrie de ces peuples a fait tout cela sans argent; car ils ne s'en servent dans aucun endroit de leur domination, \& en estiment l'usage pernicieux (p. 135).

This is of course the utopian idea of a happy land where money is unknown. It is interesting however that this society is founded on conditions of slave-labor, and that the slaves are prisoners of war, or levied after victories from defeated nations. 
Follows an exotic sort of hunting and fishing. Trained animals and birds do all the tiresome part of the hunting, after the fashion of the trained leopards of India, or the cormorants of the Yangtse boatmen. (There can be little doubt that Vairasse in his wide reading had found such accounts.) The party then proceeds through a tunnel in a mountain to the province wherein lies the capital. As Vairasse has already mentioned fish similar to those caught dans le lac de Genève, it would seem that this tunnel is a reminiscence of the mountains of Europe, for it leads directly into the streets of a city. Other traces of Alpine civilization are found. After ascending in one of two cars, attached to the ends of a cable passing through a pulley at the summit of a mountain, Captain Siden is shown a high plateau country where grazing of cattle is possible eight months of the year. At the end of the warm season,

on les fait descendre dans les vallons... parce que les neiges rendent cette montagne inhabitable ... Aussi nous n'y vîmes ni Ville ni Village, mais seulement quelques petits hameaux ... pour la commodité des bergers (p. 158).

On the journey to Sevarinde, the capital, Sermodas gives Captain Siden more light on the customs and history of the people. Of the construction of the tunnel, he says (p. 165),

rien dont les hommes puissent venir à bout n'est impossible a nôtre nation; où les particuliers n'ont rien à eux, \& où le public possedant toutes choses, \& en disposant, on vient à bout de toutes les grandes entreprises, sans or \& sans argent.

Sermodas further explains many remarkable features of the life and customs of the people by giving an account of the early life and training of Sevarias the founder of the nation (pp. 167-168). 
Sevarias nôtre premier Legislateur, qui étoit un grand Seigneur, Persan de naissance \& d'origine, avoit voyagé dans plusieurs endroits de l'Asie \& de l'Europe; . . . dès sa plus tendre jeunesse, il avoit appris les lettres grecques, \& presque toutes les sciences, sous un Précepteur Venetien,... qui l'accompagna en ce Pais, ... fut son conseiller fidele dans toutes ses entreprises, \& surtout dans l'établissement des Loix \& des Mœurs qu'ils estimérent les meilleurs. Pour cet effet ils tirérent, tant des livres anciens que nouveaux, des observations qu'ils avoient faites dans leurs voyages, \& des lumieres qu'ils avoient naturellement, les loix \& les regles de bien vivre, qu'ils établirent parmy nous.

Ideal commonwealths which have knowledge of other civilizations exist prior to the Histoire des Sévarambes. The inhabitants of the City of the Sun of Campanella, as well as those of the Nova Atlantis of Bacon, have an idea of the relative merits of 'different civilizations and religions. It is curious that Sevarias (which is merely Vairasse in an anagram) should have obtained his wisdom by travel, by a study of divers peoples, of ancient and modern books. The analogy between Sevarias, who studies, travels and then sets forth to establish a perfect state, and Vairasse, who studied, traveled, and then sat down to write an account of a perfect state, is very striking. As in the early life of Captain Siden, the campaigns and law studies of Vairasse are reflected, so here the processes of mind of Vairasse the geographer and rationalistic philosopher find reflection in the character whose name is an anagram of the author's surname instead of his given name.

Further on the way to the capital, Captain Siden is present at a review of troops, divided into three camps:

Les hommes mariés occupoient avec leurs Femmes le Camp du milieu; les Filles celui de la droite, \& les Garçons la gauche; le même ordre étoit observé dans la Ligne lorsqu'ils étoient sous les armes (p. 173). 
That women rode horseback and bore arms had been the report of many travelers to the East. In the Traicté des Tartares of Pierre Bergeron, previously referred to in connection with the Histoire des Sévarambes, occurs the following:

Les filles \& femmes sçauent aller à cheval, \& les font courir \& galoper aussi viste que les hommes. Nous en auons veu auec des ares \& des carquois (p. 341).

Elles portent toutes des calçons; \& y en a qui tirent aussi bien de l'arc que les hommes (p. 342).

There is considerable description of the uniform of the army of the Sévarambes, as well as an argument that European armies have done wrong in discontinuing the use of archers. These are said by the Sévarambes to be invaluable in routing the enemy cavalry (p. 179).

The journey to Sévarinde, the capital, is completed by boat. The city lies on an island in the center of a large, navigable river. It is geometrically arranged, having only square buildings and only straight streets. Trees are planted in regular rows. The streets can be flushed with water, and in the warm season canvas is hung from roof to roof over them so that there may be shade. This last feature is one more reflection of Vairasse's reading. In many accounts of Persia, ${ }^{30}$ the cities, and especially Ispahan, are reported as having these streetawnings.

One of the osmasies, or square buildings, is ready and waiting for occupancy by the strangers when they arrive. A full complement of slaves waits to serve them. Captain Siden's party is taken to the palace of the sun,

so It is of little importance whether Vairasse took this feature from Marco Polo, Pierre Bergeron, or Tavernier (1676). It has been pointed out in the short account of Vairasse's life, that he gave lectures on geography. He must have known many collections of travels. 
the residence of the Vice-roi $d u$ Soleil as the king is called. There is considerable description of the magnificence and size of this palace.

After ten days of sight-seeing, the company are put to work, pour nous garantir des maux où pourroit nous jetter la fainéantise (p. 192). They work only six hours a day (instead of eight, like the natives) for they have to receive instruction in the laws and language of the land. Of the language Captain Siden says, $j$ 'en compris tous les principes dans trois ou quatre mois, \& dans une année, je sus m'expliquer passablement bien (p. 196).

The Sévarambes are a resourceful and inventive people. Many inventions have added to the wealth and beauty of their land. In particular there is une invention qu'ils ont trouvée de dissoudre le sable, de l'engraisser \& de le convertir en bonne terre (p. 205). Captain Siden says that he intends to bring this invention to Europe, but it will be remembered, from the Avis au lecteur, that he died before reaching Holland. That this invention of the Sévarambes is a reflection of the Nova Atlantis or of the Terre australe connue is probable. (That part of the Histoire des Sévarambes which appeared in English ${ }^{31}$ before the Terre australe connue was published, contained no such inventions.) Certainly the Incas of Garcilaso and the Persians and Saracens of the Voyages to the Near East are not credited with any inventive power. Whereas the "miracles" of Foigny's Australians were of the type of those performed by magic - the creation of life, the control of the material by the immaterial this one invention of the Sévarambes is intensely practical. There probably never existed a more matter-of-fact, materialistic people than the people of Vairasse's imagination.

${ }^{31}$ For full account of The History of the Sevarites, cf. Appendix. 


\section{History of the Sevarambian Kings}

With the Third Part of the Histoire des Sévarambes (p. 208), comes the history of the Kings, or Viceroys of the Sun. The sun is considered as the king. The ruler, elected by the leading men, and indirectly by the people, is considered as the representative of the Sun. Of the first Viceroy, Sevarias, Captain Siden learned from the guide Sermodas, before arriving at the capital. A more complete account of his life is found in the historical part of the book (pp. 208-296).

Born in Persia, and brought up among the Parsi who were sun-worshipers and never took up Mohammedanism with the rest of their compatriots, Sevarias was a youth of great promise. He had a splendid education, and together with his Christian tutor, Giovanni (doubtless a reflection of Marco Polo), traveled in the principal countries of the world, including Italy, Egypt, Sicily and Japan. At one time, both he and his tutor were sold into slavery and separated, much in the same wayas Télémaque and Mentor. After such splendid preparation, study, and travel, Sevarias came to Australia admirably equipped to found a perfect nation, in the year 1427 A.D. To convince the natives of his right to rule, Sevarias had recourse to the use of fire-arms. This, being mistaken for lightning by the natives, made the conquest easy. All this part of the story is strongly reminiscent of the conquest of Mexico and Peru by the Spaniards.

Sevarias introduces sun-worship, abolishes corrupt moral practices, and founds granaries wherein to store food against the years of poor harvests, in the same way that the first King or Inca introduced sun-worship, abolished corrupt practices and founded granaries in Peru, according to the Histoire des Yncas. ${ }^{32}$ The rational

${ }^{32}$ Transl. from the Spanish of Garcilaso by Jean Beaudoin, Paris, 1633, and in many later editions. 
Deism of the Inca Manco Capac has been discussed in the Introduction to this study, and again in the consideration of Foigny's Terre australe connue. It will be remembered that the temple of the Sévarambes contained a globe, representing the sun, and a black curtain, representing the incomprehensible God, suggestive of the sun-worship of the Incas and of their Pachacamac or incomprehensible God. One other innovation of Sevarias in Australia has a strangely American sound. He teaches the natives to build proper bcats, as they only had de petits canots faits d'écorces d'arbre (p. 251).

The election of a successor to Sevarias, however, is not similar to the Inca system of royal succession. Having ruled thirty-eight years, Sevarias wishes to retire, and directs that an election of his successor be held. The chief men of the kingdom, being called together, elect four of their number. These four draw lots, and the "sign of the sun" falls to one Khomédas, who is then enthroned as Viceroy of the Sun.

The third member of the Sevarambian trinity - the many-breasted female figure, representing the native land - was of Asiatic origin. Similarly the election of rulers would seem to be a reminiscence of the East and not of the West. In the Traicte des Tartares of Pierre Bergeron, in which is found the account of the many-breasted idol, there occurs the following incident of the election of an emperor to succeed Cham Cingis, who left four sons:

Ces enfans auec les autres principaux Seigneurs de l'Estat assemblez, esleurent pour Empereur le fils aisné, Occoday (p. 353).

Another mention is made of the election of a successor of an emperor in the same work (p. 357).

Khomédas, who succeeds Sevarias in the story of Vairasse, builds bridges and city walls, and encourages the arts (pp. 296-298). 
Brontas, the next Viceroy, establishes new cities and quells an uprising in favor of personal property, which had been abolished by Sevarias (pp. 299-300).

Dumistas, an ambitious Viceroy, attempts to extend the territory of the Sévarambes but is prevented from so doing by the council of elders. Here again is felt the power of the representatives elected by the people (pp. 300-301).

Sevaristas has a reign of peace and abundance, extending over forty-seven years. He encourages the arts and sciences (pp. 302-304).

Khemas, sixth Viceroy of the Sun, investigates the mineral resources of the country. Ce fut lui qui fit mettre autour du grand globe lumineux du temple de Sévarinde, qui représente le Soleil, cette grande plaque d'or massif, $\&$ coupée \& gravée en rayons (p. 304). This is of course a reminiscence of the representation of the sun in the temple of the Incas, a plaque of gold which one of Pizarro's soldiers stole and then gambled away in one night, according to Garcilaso.

Kimpsas is the soldier king. He repels invasion, goes into the enemy's country and levies yearly quotas of slaves from subjected neighboring states (pp. 304-306).

Minas, the ruler at the time of Captain Siden's visit, is distinguished for having built an aqueduct (pp. 306-307).

It is true that the Histoire des Yncas contains the story of a number of kings, one of whom invaded the enemy's country and brought back slaves, ${ }^{33}$ another of whom built an aqueduct to Cuzco in the Andes as Minas is reported to have done in Australia. It is also true that the case of Khemas and the golden plaque is very much the same thing as the installation of the gold plaque in the temple of the Incas. The similarity of these two sets of incidents is too striking to be overlooked. The

as Ynca Yahuarbuacac, Histoire des Yncas, 1. iv, ch. xvii. 
general indebtedness of Vairasse to Garcilaso has been mentioned in Marchand's Dictionnaire, in the Article Veirasse and by M. Chinard..$^{34}$

The names of the Viceroys of the Sévarambes, however, are not at all suggestive of the Incas. On the contrary, these names are distinctly Persian. As Vairasse makes the law-giver, Sevarias, come from Persia, it takes little ingenuity to find in accounts of voyages to Persia such names as: Guensas, Cheselbas, Kayumarras. ${ }^{35}$ The similarity of the Persian name Gempsas ${ }^{36}$ to Kimpsas, the seventh Australian Viceroy of the Sun, is even greater. Persian names in which the letter " $K$ " occurs are common.

The publication of Bergeron's books dealing with the Near East before 1640 would seem to indicate some interest in Persia early in the 17 th century. The fact that there was a company formed in Paris pour l'établissement $d u$ commerce en Perse \& aux Indes, ${ }^{37}$ in 1665 would argue some considerable interest in the Orient before 1670 at Paris. That Vairasse knew something at least of Persia and its capital appears at the end of the Histoire des Sévarambes, when Captain Siden returns to Europe, passing through Hispahan, ville capitale de la Perse. Whether Vairasse knew the Voyages en Tartarie of Pierre Bergeron, or simply the Voyages of Marco Polo, it is very likely that he knew in addition the writings of Jean Baptiste Tavernier. It will be remembered that the Nouvelle relation de l'intérieur du sérail du Grand Seigneur of Tavernier had appeared at Paris in 1675 . That Tavernier was well and favorably known at Paris has been pointed out by M. Martino ${ }^{38}$ and others. This Nouvelle relation $d u$

${ }^{34}$ L'Amérique et le rêve exotique, p. 206.

${ }_{35}$ Traicté des Sarasins, pp. 90-98 (Bound with Traicté des Tartares, Pierre Bergeron, Paris, 1634).

${ }^{36}$ Ibid.

37 Suite des Voyages de Tavernier, Paris, 1680.

38 P. Martino, L'Orient dans la littérature française, Paris, 1906. 
sérail was reviewed in the Journal des Sçavans in $1676^{39}$ and attracted some considerable attention. In 1676 there appeared at Paris Les six Voyages de J. B. Tavernier, in which occurs a fairly complete history of the Kings of Persia. Of these, Cha-Abas the first King, set the realm in order and built a great temple. ${ }^{40}$ Another king is reported to have built an aqueduct; another discovers mines of lead, talc, and other minerals; another makes war on neighboring states.

There is every reason to believe that Vairasse, who was giving lectures on geography at this time, knew not only the Histoire des Yncas but the Six voyages de J. B. Tavernier. Undeniable traces of the Inca civilization have been pointed out in the Histoire des Sévarambes. Although there is no such close following of Tavernier in Vairasse's novel as is found later in the work of Tyssot de Patot ${ }^{41}$ and François Leguat, ${ }^{42}$ it is likely that the history of the Viceroys of the Sun among the Sévarambes is a reflection both of the Histoire des Yncas and of the Six Voyages de J. B. Tavernier. As the exterior religion of the Sévarambes is two thirds South American and one third Asiatic (Tartar), so the history of their kings is probably imitated by Vairasse on the models of two continents. ${ }^{43}$

${ }^{39}$ Year 1676, p. $18 . \quad{ }^{40}$ History of the Kings, pp. 476 et seq.

${ }^{41}$ Voyages de Jacques Massé, Bordeaux, 1710.

${ }^{42}$ Voyage et avantures de François Leguat, London, 1708.

43 The influence of travels to the Near East, bringing with them the question of polygamy, exerted a marked influence in France before 1680. Interest in harem stories has been referred to in the work of LeBlanc, Mocquet, and Tavernier. M. Lanson has pointed out the discussion of polygamy in connection with the development of the free-thinking rationalism in France, and in tracing the growth of non-religious morality. Whether or not the Biscursus de polygamia (1673) or the Polygamia triumphatrix (1676) of Jean Lyser influenced Vairasse, there were doubtless many works on the subject known to both men. M. Lanson mentions Lyser as another 


\section{Government}

The election of rulers has been described. Each small group, living in an osmasie, has a representative, elected by the people of the group. Each district has a representative elected by the leaders of the groups concerned. These in turn elect governors. The most important officials gather together, upon the death of a Viceroy of the Sun, and elect a new Viceroy, by selecting four of their number to draw lots. Thus the country is governed, despotically, by a ruler elected democratically. In the hands of the government are all food, clothing, and implements, which are doled out from central storehouses to local storehouses. The similarity of this system to that of the Incas is apparent. Both the kings of the Incas and Viceroys of the Sun among the Sévarambes are: de bons pères de famille, ou de fidèles œeconomes plutôt que des Rois. ${ }^{44}$

Naturally, the opportunity to compare this happy system with the corrupt ways of Europe is not overlooked:

il y a cette difference entre eux \& nous, que les moyens dont ils se servent pour s'élever, sont tous honnêtes \& légitimes \& que le plus souvent nous mettons en usage la bassesse \& le crime pour nous tirer de l'obscurité \& de la misére. (Sévarambes, p. 312).

Under this government, despotic but paternal, the Australian is happy, contented, and rich, for:

example of the same spirit as that found in the Histoire des Séoarambes (R. C. C., 2 avril, 1908). Discussion of the merits of Christianity as opposed to Mohammedanism, and publication on such subjects before 1634 is mentioned by Pierre Bergeron (Traiclé des Sarasins, Paris, 1634, pp. 63-64).

${ }^{44}$ Histoire des Yncas, 1. v, eh. xi. 
un exercice moderé de huit heures par jour luy procure tous ces avantages, à luy, à sa famille \& à tous ses enfans, quand il en auroit mille (p. 319).

\section{On the other hand, in Europe,}

nous avons parmi nous des gens qui regorgent de biens \& de richesses, \& d'autres qui manquent de tout. Nous en avons qui passent leur vie dans la fainéantise \& dans la volupté, \& d'autres suent incessament pour gagner leur miserable vie, ... manquant des biens de la fortune, croupissent miserablement dans la bouë, \& sont condamnez à une éternelle bassesse (p. 319).

It is interesting to note that the system of the Australians, according to Vairasse, is not radically different either from the concept of absolute monarchy as reported to exist in the Inca civilization, or from the absolute monarchy of the Tartars. ${ }^{45}$ The idea of absolute monarchy in France itself was very similar to that expressed by Vairasse in describing the government of the Sévarambes. The great distinction lies in the method of application of the theory of property. In both France and Sevarinde, the entire wealth of the land was theoretically in the hands of the ruler. In Sevarinde, however, the Viceroy of the Sun was elected to rule, and was morally responsible that each inhabitant receive what was necessary to feed and clothe him. The means of discharging this responsibility existed in Sevarinde, in the shape of central and local storehouses, and in a pyramidal system of state officials charged not only with the maintenance of law and order but also with the distribution of necessities, and the supervision of the required amount of daily work. The

${ }^{45}$ With the Incas, property belonged to the ruler, and was administered by officials. Of the Tartars it is reported (Traicte des Tartares, P. Bergeron, p. 356), Tout appartient tellement à cet Empereur, qu'il n'y a personne qui puisse ou ose dire cecy ou cela estre d̀ soy, mais tout est dे l'Empereur. 
theory of absolute monarchy in Sevarinde includes the theory of absolute monarchy of other lands, but in addition it includes the theory of the responsibility of the ruler to each individual. The placing of responsibility for the welfare of his individual subjects upon the monarch, in the Histoire des Sévarambes, is a much more dangerous and revolutionary procedure than any in the Terre australe connue of Foigny.

\section{Education and Marriage}

All children are brought up by their parents until they reach the age of seven. Children are then taken to public schools, the sexes being kept apart, and here learn to hate vice, and to obey their masters at the same time that they acquire facts. After four years, they are taught to work on the land. They spend four hours on the land and four in school. At fourteen years of age, they are taught grammar, and are given the choice of a trade. Those who are stupid are put to work as laborars and builders. Others learn a more skilled trade. All receive military training, regardless of sex. One sentence regarding the bringing up of children has a familiar sound, chaque mère est obligée d'allaiter son enfant (p. 331). This occurs cheek by jowl with laws requiring manual labor, working on the land, the learning of trades, and other practices not foreign to the preaching of Rousseau. ${ }^{46}$

Girls at sixteen years, boys at nineteen years, are allowed to associate with the opposite sex, subject to supervision, and are permitted to think of marriage. Eighteen months is allowed for this. At the end of the period, all are married. If by chance there be women left over,

${ }^{16} \mathrm{M}$. Delvaille in his Essai sur l'histoire de l'idée du progrès, p. 364, states that Rousseau knew the Histoire des Sérarambes. 
they are allowed to become the second, third, or fourth wives of public officials. An example of this has been described fully earlier in the story of Captain Siden. Lack of difference in wealth and in social standing greatly simplifies the matter of marriage. There is no such thing as ambition to marry a rich person, a person of greater education or culture, or a person of higher standing. Equality of wealth, education, and social status has abolished these evils. Equality is in fact so vital a matter, that the number of nights per month on which young married couples may use the same bed-chamber is regulated according to their age. In this manner, the Sévarambes are equal, not only as individuals but when considered as pairs.

\section{Customs}

The second volume of the Histoire des Sévarambes begins with a description of the customs of the people. Sobriety and lack of exterior forms of politeness are the salient characteristics of these people. They eat at common tables, and live happily sans Taverne ni Cabaret (vol. II, p. 9). Having no personal wealth, and receiving food and deux habits tous les ans (p. 15) ${ }^{47}$ from the government, they have no reason to sin. Honors consist in services to the state, and in this only. Of the women,

Celles qui ont eu des enfans portent autant de bandes de soye couleur de pourpre, qu'elles en ont élevé jusqu'à l'âge de sept ans, ... ce qui les rend fort soigneuses de les élever (p. 15).

The hard and fast institutionalism of Vairasse is even more striking than that of Foigny. At least the hermaphroditic brethren of the latter were uniformly naked.

47 From this point on, references are to Vol. II unless otherwise stated. 
The Sévarambes are uniformly dressed, one of their yearly garments being of cotton or linen for warm weather, the other of wool for cold weather. The working days and holidays are regulated by the sound of the bell. There are rising bells and bells that give the signal to start the day's work. As for holidays,

Le public fait souvent des parties de chasse, \& on donne la liberté aux hommes \& aux femmes de s'y trouver... tantôt à de certaines compagnies, \& tantôt à d'autres (pp. 16-17).

It is hard to realize, in reading of the customs of the Sevarambes, that it is not the description of the population of an army barracks or of a large modern battleship. That work should be arranged, planned, and regulated in a community seems natural. But that the population should be allowed to go hunting, only in shifts, by watches, or by platoons seems rather cruelty than kindness.

\section{Laws}

On ne punit jamais de mort, à moins que ce ne soit pour quelque crime énorme; mais on condamne à plusieurs années d'imprisonnement, selon la qualité du crime (p. 49).

In a long story of justice triumphant (pp. 40-48), two men are unjustly sentenced to six months' imprisonment. Later, their case is reviewed, and the judge,

Nérelias, tant pour sa Sentence injuste qu'il avoit rendue dans cette cause, que pour plusieurs autres mauvais jugemens, fut demis de sa charge, réduit à la condition de vivre en homme privé, \& exposé à la haine \& au mépris de tout le monde (p. 47).

In neither case is the punishment as severe as might be expected. In the entire chapter De la maniere dont on exerce la justice, parmy les Sevarambes (pp. 38-50) there is no mention of a citizen being reduced to slavery. 
Slaves are obtained by levies upon neighboring subject peoples, as mentioned in the reign of the Viceroy Kimpsas. ${ }^{48}$

\section{ReLigion}

The part of the Histoire des Sévarambes most distasteful to the conservative readers of the 17 th century must have been that dealing with religion. Aside from the thinly veiled satire of Christianity which occupies a large part of the second volume, there is considerable criticism plainly stated.

Only one exterior religion is allowed, bien que tous . . . ayent pleine liberté de conscience (p. 105). A priest n'a pas moins de part que les autres au gouvernement \& à la sociéte civile (p. 106). The reasons for this are fully given. On the following page (107) one reads:

il n'y a peut-être point de pays au monde ou l'on s'échauffe moins pour la religion, \& où elle produise moins de querelles \& de guerres; au lieu que, dans les autres Etats, on la fait souvent, servir de prétexte aux actions les plus inhumaines \& les plus impies, sous le masque de piété. C'est sous ce prétexte spécieux, que l'ambition, l'avarice, \& l'envie jouent leur rôle abominable, \& qu'elles aveuglent tellement les miserables mortels qu'elles leur font perdre tous les sentimens d'humanité, tout l'amour \& le respect qu'ils doivent au droit naturel \& à la société civile, \& toute la douceur de la charité, que les saintes maximes de la Religion leur recommandent.

The juxtaposition of the terms droit naturel and societe civile is noteworthy. It occurs again, a few lines later (p. 108):

48 Upon the basis of the mild nature of the laws of the Séverambes, it is difficult to understand the following sentence in M. Chinard's L'Amerique et le rêve exotique, p. 208: Du jour ò̀ un citoyen refuse d'obeir aux lois parfaites dictées par Sevarias, il est rejeté de la societté, condamné d devenir le serviteur de tous les autres, sans espoir de jamais 
Il n'en est pas de même parmy ces peuples heureux, où personne ne peut opprimer son prochain, ni violer aucunement le droit naturel sous aucun prétexte de Religion ...\& où l'on ne peut enfin s'acquerir des biens \& des honneurs, ni par les ruses, ni par les fausses apparences d'une piété feinte \& simulée.

It would seem that the theory of the rights of the individual is more a general idea of protest than an English idea. That Vairasse was convinced of the inalienable and natural right of man to freedom of conscience, freedom from persecution and freedom from the impostures of those resembling Tartufe, is evident. To say that he became convinced of these theories while in England would be hazardous.

The theory of "natural" law as opposed to "formal" law is at least as old in France as Amyot, probably older. Calvinists in France, Switzerland, and Holland held views of freedom of conscience in religion, as well as Calvinists in England.9 Vairasse doubtless went to England because he had a sympathy for the religious opinions current there. But, by the same token, he must have had very similar ideas before going. Religious and political opinions overlapped to such an extent at the time, that it is but a step from the concept of religious freedom to that of political freedom. It is not difficult to believe that the free-thinkers in France, of both Protestant and Catholic antecedents, passed from the idea of religious freedom to that of political freedom without appreciating any great distinction between the two.

After showing the rationalistic processes by which the Sévarambes arrive at the conclusion of an unknowable

pouvoir se réhabiliter. This sentence would be far more applicable to the Voyages de Jacques Massé, of Tyssot de Patot (Bordeaux, 1710).

${ }^{49}$ Pufendorf, De jure naturae et gentium, 1672, is cited by M. Lanson in this connection (R. C. C., 1909, p. 313). 
God, as well as a belief in the immortality of the soul, and after explaining the triple duty of man to the incomprehensible God, the Sun, and the native land and with enthusiasm - the following conclusion does not deceive the reader:

C'est ainsi que raisonnent ces pauvres aveugles, qui préferent les foibles lueurs de leur esprit ténébreux, aux lumiéres éclatantes de la révélation, \& au témoignage de la sainte église de Dieu (p. 114).

Even without the enthusiasm of the rationalistic exposition, the following sentences, tucked away in the body of the argument, are too pointed to admit of doubting Vairasse's opinions in the matter:

De là vient que si leur Religion n'est pas la plus véritable de toutes, elle est du moins la plus conforme à la raison humaine (p. 109).

Sévarias douta longtems s'il y avoit d'autre Dieu que le Soleil, qui est le seul que les anciens Perses reconnoissent: mais Giovanni, son gouverneur, qui étoit Chrétien, après avoir en vain tâché de le lui prouver par le témoignage des saintes écritures, le lui persuada, \& le lui fit enfin comprendre par raisonnement naturel (p. 110).

The satire of this last quotation is too keen to be passed over without remark. cvarias is represented as the wisest of men, and is, as stated before, "Vairasse" in an anagram. That this well educated, widely traveled, and intelligent man should find the existence of God possible of belief because of rational argument is natural. But that the best efforts of Giovanni should fail to convince him of this truth by using the Bible is open and pointed satire.

In addition to the Deism (and very vague future life theories) of the incas as reported by Garcilaso, and of Asiatic nations as reported by travelers, there were other influences at work on Vairasse. It has been seen 
that Foigny - through the words of Nicolas Sadeur confesses to not quite understanding the theory of transmigration of souls. With Vairasse, the theory is much more explicit. The influence of free-thinkers who wrote earlier than 1678 is evident. The world-old theory of transmigration, defended by theosophists and poets in many ages and many lands, is clearly stated by Vairasse in reporting the opinions of the Sévarambes:

l'ame des justes, après avoir passé en divers corps ou erré quelque temps dans les airs, soit dans l'orbe où nous sommes, ou dans quelqu'une des Planettes, est enfin reincorporé au Soleil, dont elle n'est qu'un écroulement, \& . . . là elle trouve son repos parfait \& entiere félicité. Pour l'ame des méchans on croit qu'au sortir du corps elle va occuper un autre dans des lieux plus éloignez de la face lumineuse du Soleil ... jusqu'à venant à s'amander, elle approche toujours où elle est enfin reincorporée, quand elle a été purgée de ses vices... Ils ne croyent pas... que l'ame d'un homme puisse passer dans le corps d'une bête. (vol. II, p. 117).

The allegory of the sun is still present, to make less hardy this plain statement of transmigration. The note of evolution of the soul and its progress toward perfection is definitely present here, as in the theories of earlier theosophists. The vulgar idea of man's soul taking on the body of a beast, because of sin, is rejected by Vairasse, who stands (with other enlightened theosophists) upon the dignity of man, and upon his essential difference from the beast. Other free-thinkers of the 17th century before Vairasse had expressed their feeling of the reality of other planets, Cyrano de Bergerac and his fantastic novels being the best remembered. This astronomical vision flowers toward the end of the 17th century, bringing the planets within the horizon of the average reader, who had previously considered his own world and an orthodox hereafter the only field for speculation. 


\section{Laws and Prayers of Sevarias}

The principal laws of Sevarias, which he left to the Sévarambes at the time of his death, and which express the theories of Vairasse, are ten in number (vol. I, pp. 281-283). Those regarding private property, useless occupations, education of children, and the evils of leisure may be passed over as taken from Plato, More, Bacon, or Campanella. Some of the laws, however, are more typical of Vairasse and are more stressed in the story:

1. De ne pas permettre de dignité héréditaire.

2. De punir l'intempérence en toutes choses.

3. De faire valoir les loix du mariage... pour la propagation de l'espèce.

4. De faire valoir la religion pour lier les hommes par la conscience, leur persuadant que rien n'est caché à la Divinité.

Naturally, hereditary honors have been called into question ever since man first began to reason, and it would be futile to attempt an investigation of the source of Vairasse's theory in this connection. The point is that he insists upon this principle throughout his novel. The doctrine of temperance is another ancient precept. The interest of Vairasse in temperance is, however, closely connected with his hatred of celibacy and his evident predilection for polygamy, and the license of Mohammedan civilization. With regard to the third principle enumerated, De faire valoir les loix du mariage ... pour la propagation de l'espèce the point of view of Vairasse is the same as with regard to temperance. Of course the idea is not new with Vairasse, even in the 17th century. It is found in the Civitas Solis of Campanella.50 The idea of binding men by con-

so Before Campanella, the idea of "generation to preserve the race" is found in St. Thomas Aquinas. In this connection see R. de Gourmont, La culture des idées, Paris, 1900, p. 210. 
science is a rational, not a traditional conception of religion..$^{51}$

Besides the Laws of Sevarias, there remains his long Deistic prayer, under the title Oraison du grand Dieu (vol. II, pp. 218-221). After a list of titles which the Sévarambes use in addressing the unknowable God nine titles, five beginning with " $K$ " and all ending with "as" - comes the prayer. Part of it reads (pp. 218-221):

Nous aveugles mortels, qui vous entrevoyons sans vous bien voir, qui vous connoissons sans vous bien connoitre, \& qui néanmoins croyons vous devoir adorer; nous venons ici au milieu des ténebres qui nous environnent, pour vous rendre nos vœux \& nos hommages. Toutes choses ici bas nous parlent journellement de vous... Dans cet humble sentiment, nous mettons le doigt sur la bouche; \& sans vouloir témérairement pénétrer dans les mystercs profonds de votre divinité, nous nous contentons de vous adorer dans l'intérieur de nos âmes.

There is no passage in Foigny's novel that approaches this prayer in style. Among other things in this long prayer is a reference to the sun, the visible representative of the unknown God, which is doubtless thrown in for effect. The sun, and the many-breasted female idol representing the native land are brought in from time to time throughout the story, and add an exotic and

${ }^{51}$ It is to be noted that an Histoire crilique du vieux Testament of Richard Simon appeared in Paris in the same year as the $\mathrm{II}^{\mathbf{e}}$ Partie of the Sévarambes (1678). The catalogue of books in the Journal des Sçavans for 1677 mentions both a book Les Imposteurs insignes and Du Ryer's translation of the Koran (1st ed., 1647) at Amsterdam. A considerable interest in comparative religion at the time must have furnished Vairasse with many ideas.

There is considerable theological material which Vairasse might have used in the Histoire de la dernière rérolution du Royaume $d u$ Grand Mogol, 1671, of François Bernier, but I cannot find any positive trace of Vairasse knowing this very interesting and splendidly written account. 
authentic atmosphere. The pleading of Vairasse for a rationalistic and Deistic conception of God, is, however, genuine and impassioned.

\section{Language}

There is a long and detailed account of the language of the Sévarambes (pp. 249-269). It includes not only a complete treatment of the phonetics, grammar, and syntax of the language, but a consideration of theories of versification. The history of the language is particularly interesting.

Sevarias, on coming to Australia, finds a simple people, (the Stroukarambes) who had peu de termes, parce qu'ils n'avoient que peu de notions (p. 250). This wise man suppressed certain unnecessary words of this simple language, and to it he added many words for which a necessity existed. He created a language upon this basis which had ten vowels and thirty consonants. As an aid to pronunciation, he invented certain modelwords, in which the distinction between sounds would be apparent, afin que les enfants apprissent de bonne heure à former toutes sortes d'articulations, \& à rendre leur langue flexible \& capable de prononcer tous les mots (p. 251).

The theories of Vairasse on phonetics are definite. The vowels are arranged according to

l'ordre de la nature, commençant par les voyelles Gutturales, puis venant aux Palatiques, \& finissant par les Labiales (p. 252).

Consonants are Primitives \& Derivées. The latter class is subdivided into the séches and the mouillées. Consonants are arranged according to another classification, as Gutturales, Palatiques, Nasales, Gingivales, Dentales, \& Labiales (p. 253). 
Whereas the spelling of the word implied a knowledge of the nature of the object with Foigny, the Sevarambes ont fort étudié la nature des choses qu'ils tâchent d'exprimer par des sons conformes, ne se servant jamais de syllabes longues $\&$ dures pour exprimer des choses douces \& petites (p. 253).

Dipthongs and tripthongs exist in the language of Sevarias to the number of thirty. Marks of punctuation are used, not only for questions and exclamations but pour exprimer la joye, la douleur, la colere, le doute (p. 254).

The grammatical pedant that was Vairasse stands forth in this sentence (p. 254):

Jamais ils ne mettent le circonflexe que sur les lettres longues $\&$ ouvertes, ny le grave que sur celles qui se prononcent en fermant la bouche \& qui . . . abaissent la voix.

There are three genders, as well as a number of terminations to denote large or small size, pleasant or unpleasant qualities. When it is noted that the verbs have each three conjugations, one for masculine subject, another for feminine subject, and a third for neuter subject, the simplicity seems to have ended, and the complications to have begun. There are, however, no irregular verbs, and having mastered one verb one has. mastered all. There are verbes imitatifs, des inchoatifs and many others. Such a verb as ermanei, ${ }^{52}$ which means aymer un peu mais joliment (p. 258), would seem to be a useful verb for the polygamous state officials.

With regard to syntax and order, and their relation one to the other, Vairasse considers the question in its large aspect. With the Sévarambes, word-endings are so distinctive, that they arrangent leurs mots comme il leur plait (p. 267). This, he says, was the ideal of classical Latin, although the similarity of endings in that language

62 The inability of the author to avoid altogether his own language is evident. "Ermanei" is simply "aimer" plus " $n$ " and "e." 
made some rules of arrangement necessary. Of course, crude languages such as those spoken in Europe cannot hope to have the flexibility of the language of Sevarias. From this point of view, Vairasse would seem to revere the ancients as compared to 17th century French writers. $\mathrm{He}$ is however, strongly opposed to rime and considers it a barbarism. Captain Siden says (p. 262),

Je voulus une fois ... parler de nos Vers rimez, ... mais ils traiterent cela de ridicule \& de barbare, disant que les rimes ne faisoient que gêner le bon sens \& la raison.

He goes on to ridicule the rime of speeches on the stage, and in general all people who rime their lives, their wills and their last words. As a grammarian and a rationalistic thinker, Vairasse could not be expected to be in favor of rime.

Although the quarrel of the Ancients and Moderns in French literature is generally considered to have assumed proportions of importance after 1680, it will be remembered that Desmarets de Saint-Sorlin wrote his Défense de la poésie et de la langue française in 1675. Likewise the quarrel over the inscription of a triumphal arch ${ }^{53}$ dates from 1676. It is however interesting to find the ideas of Vairasse on the subject of rimed verse to be practically the same as those of La Motte-Houdar. Vairasse was publishing these ideas on the subject of rimed verse in the Histoire des Sevarambes (Second Part) in 1678-1679, when Antoine Houdar de la Motte was seven years of age. The condemnation of rime, generally thought of as an 18th century development of the quarrel, is present in 1679 in the Histoire des Sévarambes of Vairasse. ${ }^{54}$

*3. Charpentier, Defense de la langue françoise pour l'inscription d'un arc de triomphe, Paris, 1676, and other works. See G. Lanson, Manuel bibliographique, Querelle des anciens, etc.

${ }^{54}$ A long citation from the Histoire des Sévarambes (princeps edition), dealing with rimed verse, will be found in the Appendix. 


\section{Omigas, the Imposter}

There are forty pages in the second volume of the Histoire des Sévarambes devoted to the deceptions of an imposter called Omigas by his own following, and Stroukaras by the Sévarambes. It was Omigas who led the populace crédule, superstitieuse, grossiére, before the coming of Sevarias.

Nine of his "miracles" are recounted:

1. He made his face shine by artificial means.

2. He pretended to hold conversation with the sun.

3. He pretended that birds brought him food.

4. He pretended to send eagles to heaven with messages.

5. He pretended to cause rain after a drought.

6. He used accomplices to carry out spurious cures.

7. He built a covering over a pit, and pretended that the earth had swallowed his enemies when he let them down into the pit suddenly, by allowing the covering to fall.

8. He pretended that he was the son of the Sun.

9. He sealed a spring in a rock, and then, by striking on the fragile covering with a staff, let the water run out.

When the people are informed of the methods employed in performing these miracles, they are indignant and for a long time refuse to believe them spurious. The cold reason of Sevarias does finally convince these superstitious people of the fraud, however. The history of Omigas or Stroukaras occupies about forty pages (pp. 134-173).

Follows a long story of the love of Dionistar and Ahinomé. One of the priests of the false prophet falls in love with the beautiful Ahinomé, and tries to obtain her admission to the temple. At this, she and her lover flee:

Il faloit éluder les desseins des Prêtres lâcifs qui vouloient faire d'Ahinomé un instrument de leur détestable luxure (p. 178). 
Ahinome burns down the temple, escapes with her lover, and spends years with him in a rocky fastness. They have five children in this seclusion. The priests learn of their hiding place, and cut off their source of supplies. When the lovers are nearly starved, Dionistar calls for a discussion, speaks to the assembled priests and people, denounces the licentious conduct of the clergy, and then commits suicide. His wife likewise kills herself, and dies with him, before the others can interfere.

In the account of Omigas' life the resemblance to the miracles of the Old and New Testaments, is so great and in the tragic story of Dionistar and Ahinome the criticism of the priesthood is so virulent, that these important parts of the Histoire des Sévarambes have been omitted in some later editions. In particular, the Histoire des Sévarambes contained in the large Bibliothèque des voyages imaginaires ${ }^{55}$ lacks these two parts entirely, besides other less important matters.

Vairasse here again speaks definitely against revealed religion, against the validity of miracles, and against the privileges of the clergy. Regardless of the opinions of the reader, Vairasse stands condemned of very bad taste in this part of his novel. His condemnation of the clergy is vitriolic in its force, and one man's bigotry is as displeasing as another's when unrestrained.

\section{Digressions}

Aside from the account of Omigas and the story of Dionistar and Ahinomé, there are other digressions in the second volume. One, dealing with a law-case, has already been referred to. Another (pp. 20-36), treating the love affairs of young people in the public schools,

ss Amsterdam, 1787-1789, vol. v. It is this edition that is cited by $M$. Lichtenberger and by $M$. Chinard. 
and with the escapades of two young men who succeed in gaining admission to the girls' dormitory, is strongly reminiscent of accounts of travelers to Mohammedan countries. A digression, the story of the poet Franoscar and his lady Balsimé (vol. II, pp. 257-276), is tinged with the same Mohammedan influence. The Viceroy of the Sun falls in love with the lady and would make her one of his wives, but, on learning that she loves the poet, the kind sovereign renounces his rights to the lady's hand, and treats both lovers bounteously.

\section{Inventions}

The invention of making sand into fertile earth has been mentioned in the part of the story of Captain Siden in which the party first arrives at Sevarinde, the capital. Two other inventions are:

des orgues d'eau, meilleures que celles où l'on ne se sert que du vent (vol. IIi, p. 37);

le secret de fondre le cristal, comme nous fondons le verre (vol. II, p. 73).

\section{The Return to Europe}

After two hundred pages in which there is no mention of Captain Siden, and in which there is no attempt at continuity, the hero is again brought in. The manner of Captain Siden's leaving the Austral land, and the reasons given by him for his return to Europe, leave the reader little respect for his character. It was Siden who, shortly after the shipwreck, distributed the women of the company. It was Siden, who said of himself, shortly after arriving at Sevarinde:

Nous avions tous des Femmes \& j'eus permission d'en avoir jusques à trois, \& mes Lieutenants deux (vol. I, p. 196). 
Now, at the end of the second volume, he seeks permission from a member of the council to return to Holland:

sous promesse de revenir avec ma femme \& les enfans que j'avois laissés en Hollande, comme je le lui faisois accroire, pour avoir un juste prétexte de revenir en Europe (p. 297).

Captain Siden will be willing to return to Sevarinde again,

pour y passer le reste de mes jours, quand j'aurai satisfait au violent desir que j'ai de revoir ma Patrie, \& d'y prendre avec moi une personne qui m'est fort chère, si je la trouve encore en vie. . . . mon desir est d'autant plus juste \& raisonnable, qu'outre les avantages de ce pays, j'y ai laissés trois femmes \& seize enfans . . . que je n'aurois pas laissés pour un moment, si l'envie de joindre à leur nombre le premier fruit de mes amours ne m'y eut fortement sollicité (pp. 297-298).

It is, of course, difficult to judge regarding right and wrong in the case of a man torn between a loved one in Europe and three wives and over a dozen children in Australia. The conscience of Captain Siden is a strangely constructed mechanism. Speaking of his friend Calsimas, who aided him in returning to Europe, he says,

il me permit de m'embarquer secrétement... apres m'avoir fait promettre de revenir $\&$ de ne point parler de leur nation aux peuples de nôtre continent (p. 298).

The fact that Captain Siden (as explained in the Avis au lecteur preceding the Histoire des Sévarambes) died before reaching home, relieves him from the responsibility of publishing the story of the Sévarambes, after having promised to maintain silence about them. The fact that he is supposed to have written some part of it after obtaining permission to return to Europe is rather a challenge to his good intentions.

The return journey, from Australia to the coast of 
Persia, takes sixty-eight days. There are no details of the trip, not even the direction being indicated. Previous mention has been made of Captain Siden's passing through Hispahan, ville capitale de la Perse (p. 301), and of his death from wounds received just before reaching Holland.

\section{Conclusion}

This Extraordinary Voyage is based for its realistic beginning directly upon the account of Captain Pelsart's shipwreck on the coast of Australia. The atmosphere of the imaginary society described is Mohammedan, polygamy and an interest in adventures of an amorous nature being salient features of it.

The religion of the Sévarambes is Deism, with external features resembling the religion of the Incas as reported by Beaudoin's translation of Garcilaso, as well as of the idols of the Tartars as reported by Marco Polo and Pierre Bergeron. A satire of the miracles of the Old and New Testaments is found in the long digression concerning the imposter Omigas The priesthood of Europe is criticized in the story of the love of Dicnistar and Ahinomé.

The government of the country is despotic, but the despot is elected democratically. The despot is responsible, through his representatives, for the feeding, clothing, and housing of his subjects.

Equality of education, of clothing, of lodging, and of food is required by law. Marriage is compulsory. Children are educated and housed in public schools from the age of seven. Military service is obligatory for both sexes. Work on the land is required of all children until they demonstrate their fitness for higher types of labor. State officials are permitted to have plural wives. Others 
are limited to one wife. The clergy are not exempted from civic duties.

The language of the country is a "created" language, and is based on logical principles rather than on tradition. Rimed verse is not in use, and is considered barbaric..66 s6 A long citation relative to rimed verse from the princeps edition (1678-1679) will be found in the Appendix. 


\section{CHAPTER VI}

\section{A POLITICAL SATIRE AND TWO TRANSLATIONS}

1. L'Île de Borneo, of Fontenelle.

2. Le Philosophe Autodidacte, of Ibn Thofail.

3. Le Criticon, of Baltasar Gracián.

\section{L'Íle de Bornéo}

In Bayle's Nouvelles de la République des Lettres, in January 1686, there appeared the youthful Fontenelle's Relation de l'र̂le de Bornéo. This short account (five 12mo. pages), purporting to have been written from Batavia, and contained in a letter from Fontenelle to M. Basnage at Rotterdam, was a thinly veiled satire of the religious disputes in France at the time. Coming on the heels of the Revocation of the Edict of Nantes the names of the characters "Mreo" and "Eenegu" were easily transposed by the reader to "Rome" and "Genève," and by analogy to "Catholicism" and "Protestantism." The "Bornéo" of this brief account is simply France under another name, and offers no virtues to be imitated by the French.

This satirical Relation is mentioned here to show clearly the difference both in purpose and form between this type of satire and the novel of Extraordinary Voyage.

\section{Le Philosophe Autodidacte}

Another sort of imaginative work known in France before 1700, but of foreign authorship, is the Hayy ben Yaqdhan of Ibn Thofail; - a gifted Moslem author born 
in Guadix, near Granada, about 1110. M. Lanson ${ }^{1}$ has mentioned an analysis of this work in the Bibliotheque universelle for 1686, under the title Le Philosophe autodidacte. There is a history of the publication of this novel in the work of M. L. Gauthier. ${ }^{2}$ Those wishing to read the Hayy ben Yaqdhan carefully published in French are referred to the translation of M. Gauthier, published at Algiers in 1910.

The novel is the life story of Hayy ben Yaqdhan, who grows from infancy to manhood upon a desert island without human companionship or instruction. Hayy discovers by native intelligence not only the laws of physical things but also the mysteries of esoteric religion. Upon learning human speech from a man who chances to visit the island, Hayy attempts to convey a knowledge of these mysteries to the inhabitants of a neighboring land. Finding this task impossible of execution, he returns to his island to pass the remainder of his life in contemplation.

The inherent virtue of uninstructed man - the "primitive man" of years later - is extolled in this novel of amazingly wide philosophic scope. Translations and analyses of the Hayy ben Yaqdhan, although known in France before 1700 , seem to have had no influence on the French novel until after the end of the century. ${ }^{3}$

\section{Le CRITICON}

A translation of the Criticon of Baltasar Gracián (15851658) appeared in France in $1696.4^{4}$ It contained only

1 Origines et premières manifestations de l'esprit philosophique, Reoue des Cours et Conférences, 1909.

${ }^{2}$ Ibn Thofaīl, sa vie, ses ceuvres. Paris, 1909.

3 For importance in English Literature, cf. Martha P. Conant, The Oriental Tale in England in the 18th Century, New York, 1908.

4 L'homme détrompé, ou le Criticon, transl Maunory (first Part only). 
the first part of this novel, the complete translation appearing only after the beginning of the 18th Century. ${ }^{5}$

The first part of the Criticon is very similar to the Philosophe autodidacte originally written by Ibn Thofaill. Señor D. Marcelino Menéndez y Pelayo, in the Prólogo of El Filósofo autodidacto de Abentofail, ${ }^{6}$ remarks the evident indebtedness of Gracián to the Arabic novel, and laments the fact that the source of his knowledge of the earlier work is unknown.

The Criticon opens with the arrival at the island of Saint Helena of Critilo the lone survivor of a shipwreck. Having come ashore, this man tries to speak with a youth, Andrenio, who like Hayy ben Yaqdhan has grown to manhood without knowledge of human speeches. Having learned to talk, Andrenio shows that he has formed his own concepts of the world, that he has conceived unaided the idea of a Deity and, in addition, a love for this Deity as manifested in nature. Here, as in the earlier Arabic novel, is a vindication of the inherent virtue and wisdom of uncorrupted man. It is in the stressing of moral rather than philosophical considerations that Gracián differs most markedly from his predecessor. ${ }^{7}$

The work of this moralist has long been recognized as having an influence on the character of Man Friday in the Robinson Crusoe. Apparently no influence was exerted on 17th century French writers by translations of Gracián and Ibn Thofaĩl. In 1708, however, there appears a French novel, of the desert island type, strangely like the Robinson story of years later. ${ }^{8}$ It happens that Defoe

5 L'homme universel, transl. P. de Courbeville, 1723.

- Zaragoza, 1900.

7 Cf. Ernest Seillière, Un grand moraliste oublié: Balthasar Gracian, Institut de France. Acad.d. sci. mor. et polit. Séances tt travaux, n. s. v. 73, pp. 474-492.

${ }^{8}$ Les Voyages et aventures de François Leguat et de e`s compagnons, London, 1708. This strange book, whose realistic setting is taken 
was a man of genius and that the French author of years earlier was a mediocre writer. But the novel of a contemplative life on a desert island appears to have been influenced, both in English and in French Literature of the 18th century by translations of the works of Thofail and of Gracián.

from French Relations de Voyages, is definitely a French creation. It was translated into English and published at London in the same year that it appeared in French. Copies of both the English and French versions are in the British Museum. The study of this novel will be undertaken by the present author in another volume on the Extraordinary Voyage in French Literature after 1700. 


\section{CHAPTER VII}

\section{LES AVENTURES DE TELEMAQUE OF FENELON}

1. The Extraordinary Voyage.

2. The Ideal State.

3. The Reformed State.

4. General Concepts.

5. Conclusion.

\section{The Extraordinary Voyage}

Fennelon is the only great author of the 17th century who wrote a novel of the type of the Extraordinary Voyage. The Aventures de Télémaque ${ }^{1}$ has been considered from so many points of view, by so many able critics, that for the present study there remains only to classify it with relation to other novels of Extraordinary Voyage. Although in spirit a didactic poem, this work has the form of a novel, and presents many of the characteristics of an Extraordinary Voyage as here defined. If it be admitted that the travels by land and sea of young Télémaque are made to countries which exist, but of whose civilization at the epoch of these travels little is known, then this novel falls within the definition given. Although Minerva, in the guise of Mentor, accompanies Télémaque in a great part of his travels, these travels are made by means which are possible. There is nothing

1 Paris, 1699. The history of the publication of the Telémaque by Fénelon, the object of its composition for the education of the duc de Bourgogne, and the events following its publication, are too well known to require extended treatment here. The bibliography of the subject is contained in the Manuel bibliographique of M. Lanson. 
marvelous or fantastic in these means themselves. With regard to the descent of Télémaque, while still alive, into Hades (Livre xiv), it can only be said that this journey is reported to have been made by other living heroes belonging to the same epoch of history as Télémaque. To attempt to prove authenticated realism in the Aventures de Télémaque would be futile. However, once in the atmosphere of ancient Greece which permeates the book, there is no striking lack of consistency, as far as the story itself is concerned.

Transparent references to society in Europe on the part of the author do tend to spoil the illusion, it is true. But it is by this very polemic element that the Aventures de Télémaque is bound to the other Extraordinary Voyages. Whereas the novels of Foigny and Vairasse have only infrequent passages showing any beauty of style, and whereas beauty of style is a salient characteristic of the work of Fénelon, the Télémaque suffers from the same desire to preach on the part of its author that has been noted in the earlier novels of the type. Here, as in other Extraordinary Voyages, the adventures of the hero are merely the medium in which is borne the political, social, and philosophical content. This content does not come naturally from the events of the story, but rather directly from the mind of the author. That Fenelon's hero travels through the ancient world of the Eastern Mediterranean instead of the new worlds of Australasia, that these travels are told in a style that is lofty and poetic instead of rough and virile, distinguishes this novel from its predecessors of the same general type. But the rationalism of Fénelon, his hatred of the abuse of power, his convictions concerning the ideal state and its dependence both upon agriculture and the absence of luxury, all these conceptions bind the Télemaque not only to the Terre australe connue and to the Histoire des Sévarambes, 
but also to the mass of similar writings which follow in the 18th century.

The ability of Fénelon to couch his personal ideas in a style that was pleasing, together with his prominent position at court, gave his novel a much greater influence than that enjoyed by the other Extraordinary Voyages of the 17th century. Because of these two factors, the Télémaque is read - willingly or unwillingly - by a great many people to this day. It continues to be read at the present time rather in spite of its polemic element than because of it. On the other hand, Foigny and Vairasse, lacking both the social position of Fénelon and his genius for expression, had a limited public for such time as their ideas retained the interest that comes of novelty. They were read because of their rationalistic and adventurous elements, and rather in spite of their style than because of it. When the interest in such ideas became more widespread, the increased public turned by preference to more artistically constructed works, written by men of greater genius in expression.

M. Le Breton has called attention to the fact that the T'élémaque appeared more like a novel to a 17 th century public than it does to modern readers. ${ }^{2}$ He likewise traces an element of adventure common to the school of d'Urfé and to this novel of Fénelon. ${ }^{3}$ M. Chinard has noted a general similarity between the adventures of this Greek hero and the heroes of exotic novels and accounts of exploration and adventure beyond the seas. ${ }^{4}$ It is of course easy to feel in this novel the influence not only of the Greek epic but of the Italian and Spanish pastoral. Although the art of Fenelon would tend to produce an opposite impression on the average reader, it is strange when one has read a large number of 17 th century accounts of

${ }^{2}$ Le Roman au xviii ${ }^{\circ}$ siecle, p. 2.

Ibid., p. 8.

- L'Amérique et le rêve exotique, pp. 215 et seq. 
adventure and discovery in new continents, how much at home one feels in reading the Télémaque. That anything more than slight traces of other books of travel should be found in the T'elemaque is not to be expected. In the case of Fénelon, it is not a question, as it was with his predecessors, of determining the indebtedness of the author to this or that account of travel in far lands. It is almost enough to indicate the shipwrecks, the description of the port of Tyre (Livre iii), with its breakwaters, shipyards, polyglot population and bustle of trade, together with the clearing of land for agriculture in several kingdoms, which savors of new countries rather than of old. ${ }^{5}$

There is no necessity for analysis of so well known a story as the Aventures de Télémaque. Neither does the mythology involved, and the supernatural appearance of gods to men in the novel need to be insisted upon. It would be useless, likewise, to point out the numerous cases in which Fénelon calls attention to the virtues or vices of this or that King for the enlightenment of the duc de Bourgogne. There are two main elements of the book, however, which are worthy of careful consideration here. These are:

1. The presentation of two states (La Bétique and Salente), the one ideal, the other practical.

2. General considerations as to royalty and absolute power, theories of government, wisdom and efficacy of laws, property, rights of citizens, and Nature.

\section{The Ideal State}

An ideal commonwealth, La Bétique (Livre vii) is reported by Adoam to Télémaque. The travelers never see it themselves, but learn of its charms from a man

${ }^{5}$ A slightly more detailed imitation of the accounts of American Indians will be found in the discussion of $L a$ Betique which follows. 
who follows the sea. This ideal State is a reflection of other ideal commonwealths as reported by More, Bacon, Campanella and others, with certain extensive modifications. The climate of this happy land is equable. Money is not in use. The inhabitants are cut off from other nations, on one side by high mountains, on the other by the sea. No other people has conquered them, for they prefer liberty to life. They never have wars with other lands. They are cordial to strangers, but have no desire to travel and to become acquainted with other lands. The inhabitants of $L a$ Bétique gladly allow strangers to work mines in their country, but prefer for themselves the fruits of the earth's surface to the gold and silver to be found beneath. Practically all the inhabitants are either tillers of the soil or shepherds. They have no cities, no buildings, no building trades; they are not attached to any material things. Having no houses, they live like the nomads of the deserts or rather like the American Indians, having for residences:

des tentes, dont les unes sont de peaux cirées et les autres d'écorces d'arbres (Livre vii, p. 143). ${ }^{\circ}$

Tous les biens sont communs (p. 145).

Ils sont tous libres et égaux (p. 145).

Chaque famille, errante dans ce beau pays, transporte ses tentes d'un lieu en un autre, quand elle a consumé les fruits et épuisé les pâturages de l'endroit où elle s'était mise (p. 145).

Again like the American Indians, it is the women who do a good share of the work; particularly the making of shoes is the work of women:

Elles emploient le cuir de leurs moutons à faire une légère chaussure pour elles, pour leurs maris, et pour leurs enfants (p. 143).

- References are to Aventures de Telémaque, ed. Didot Frères, Paris, 1859. 
M. Chinard has indicated ${ }^{7}$ the similarity of the civilization in La Betique to that of the American Indians as reported by the missionaries in Brazil and in Canada. What is perhaps as important as this undoubted indebtedness on the part of Fénelon is the difference between this ideal state and ideal states of earlier authors. The people of $L a$ Bétique have no institutionalized society, no slaves, no wars, no mines, no interest in wealth or material things. This serves to differentiate them from all imaginary peoples previously reported to have been found. Foigny succeeded in imagining a society free of slaves, and free from almost all interest in material things - but wars existed even in the Australia of the bisexual brothers. The Bétique of Fénelon is by far the most complete and consistent account of a colony of simple, peace-loving, free-and-equal people. Here is no institutionalism. Nothing of the earth, nothing of passion, hate, fear, or ambition renders these divinely happy people similar to other human beings.

The question naturally arises: How did these people attain this unearthly virtue? The answer is not far to seek; but that it should come from an ecclesiastic, and before 1700 , is striking.

Ces hommes sages... n'ont appris la sagesse qu'en étudiant: la simple nature (p. 144).

Télémaque... se réjouissait qu'il y eût encore au monde un peuple, qui, suivant la droite nature, fût si sage et si heureux tout ensemble... Nous sommes tellement gâtés, qu'à peine pouvons-nous croire que cette simplicité si naturelle puisse être véritable. Nous regardons les mœurs de ce peuple comme une belle fable, et il doit regarder les nôtres comme un songe monstrueux (p. 150).

It has been seen that Foigny's Australians did not sin in Adam, and that therefore his novel was considered ${ }^{7}$ L'Amérique et le rêve exotique, pp. 216-217. 
sacrilegious. The general pagan atmosphere of the Télemaque throws one off the scent in this regard. The fact remains that by following, unenlightened, "la droite nature," and by studying, unenlightened, "la simple nature," these people have maintained an original perfection unknown not only in ancient Greece, but also in 17th century France. Here in $\mathbf{1 6 9 9}$ are the fullblown "good savage" of the 18th century and the poetic, nomadic Indians of Chateaubriand.

\section{The Reformed State}

In the Kingdom of Salente (Livres $\mathrm{x}$, xi, xvii) is a different concept from that found in La Bétique. The realm of King Idoménée, Salente, being in many ways similar to European communities of the 17th century, is in need of reform in order that it may become more perfect. The reforms are effected and the results noted. This is distinctly new in one sense.

In the Terre australe connue of Foigny, in the Utopia of More, the Nova Atlantis of Bacon, the Civitas Solis of Campanella, a gradual process of development has taken place. At the time of the visit of the explorer, the perfected civilization is a fact of long standing. In the Histoire des Yncas of Garcilaso and in the Histoire des Sévarambes a high type of civilization is reported to have been developed by a wise leader and his followers. But in these two cases the wise man came into a barbarous country where practically everything remained to be done, and where no traditions opposed the installation of the new way of living. In Salente, it is a case of reforming a fairly high type of civilization which already exists. This is a striking novelty. Other imaginary lands in which the people have faults, vices, and suffering have been presented satirically. Such are Les Herma- 
phrodites of Thomas Artus and the Relation de l'âle de Bornéo of Fontenelle. In the Salente of Fénelon, occurs for the first time synthetic criticism of society, suggestion of reforms, practice of reforms with the results demonstrated. The idea of progress is definitely present.

In the history of the reforms carried out in Salente, (Livres $\mathrm{x}, \mathrm{xi}$ ) it is not a question of an unbelievable kingdom of the imagination. Mentor suggests to Idoménée one reform after another to lead his people to virtue. Social, legal, and educational remedies are suggested for existing evils. These are put into practice. Later (Livre xvii), when Télémaque returns to Salente, he cannot believe his eyes. In a short time the reforms have been carried out. Télémaque remarks the simplified life of the people, the lack of useless ornaments and luxury of all sorts in the city, and the flourishing condition of the surrounding country districts. Mentor explains to him in detail this remarkable change, but the most striking amelioration is that resulting from the return to the land:

Tout le pays n'est qu'une seule ville; Salente n'en est que le centre. Nous avons transporté de la ville dans la campagne les hommes qui manquaient à la campagne, et qui étaient superflus dans la ville. De plus, nous avons attiré dans ce pays beaucoup de peuples étrangers. On n'a rejeté de cette ville que les arts superflus, qui détournent les pauvres de la culture de la terre pour les vrais besoins, et qui corrompent les riches en les jetant dans le faste et dans la mollesse; mais nous n'avons fait aucun tort aux beaux-arts, ni aux hommes qui ont un vrai génie pour les cultiver (pp. 392-393, Livre xvii).

A striking sentence of Mentor is that dealing with the past magnificence and pomp of the court of Idoménée:

Cet éclat éblouissant cachait une faiblesse et une misère qui eussent bientôt renversé son empire (p. 393). 
In books $\mathrm{x}, \mathrm{xi}$, and $\mathrm{xvii}$ occurs the welding, thanks to the idea of progress, of two elements in literature that had long remained separated: the destructive satire and the far-off utopia. Regardless of Fénelon's intentions, and whether or not satire of Louis XIV is intended, there is here a demonstrated reform of a society not unlike that found in France toward 1700. Uniform clothing according to rank and other external features borrowed from preëxistent utopias are found to be sure, but the indirect suggestion by example of the earlier ideal accounts is left far behind. Such radical changes as abolishing private property and money are not attempted. Only remedies which seem practical are suggested. The reader of the three books dealing with Salente in the Aventures de Télémaque is informed of remedies which will change evil conditions, such as exist in France, and is permitted to see the practical prosecution of these reforms, and the results of their application in Salente.

Fénelon was not alone in having ideas of reform at this date (1699). Colbert had died in disgrace sixteen years before, and the extravagance, wars, and persecutions of the years following his death doubtless caused many to think seriously upon the matter of state expenditures and their relation to taxation. There also comes in the last twenty years of the 17th century a well defined feeling that the masses are imposed upon for the benefit of the few. These sentiments find expression after the end of the 17th century, in the Projet de dîme royale of Vauban $^{8}$ and in many other protests. ${ }^{\circ}$

\section{7.}

- For general aspects of this spirit of dissatisfaction in France before 1700, see G. Lanson, Histoire de la littérature française (Les origines du xviii siècle), and Le rôle de l'expérience dans la formation de la philosophie du xviiie siècle en France. Revue du Mois, 1910. Also J. Delvaille, Essai sur l'histoire de l'idée de progrès, Paris, 1910, pp. 245-247. 
Doubtless the ideas referred to were shared by Fénelon with many others at the time the Télémaque was written.

\section{General Concepts}

That a man of the culture of Fénelon should have had many ideas, and ideas of a general philosophic nature, is only natural. His genius however lay in his ability to formulate these ideas in words, and more particularly to state them in epigrammatic form. One source of Fenelon's influence must be sought in these epigrammatic statements, which lend themselves to quotation and which are therefore remembered after the details involved in the particular work are forgotten. This same ability to express general concepts in terse form is a characteristic not only of Fénelon, but of many other writers of his epoch. It may be said in passing that La Rochefoucauld lives to this day because of this one quality. Epigrammatic ability of expression on the part of Fénelon causes one to remember to-day the statement of Socrates to Alcibiades: ${ }^{10}$

Le droit de conquête est un droit moins fort que celui de l'humanité.

The Télémaque shares with the Dialogues des Morts this richness in epigrams, and was therefore a particularly forceful novel of social criticism. It is worth while therefore to consider some of these in the Télémaque, and to divide them into classes.

\section{Royalty}

Quiconque est capable de mentir est indigne d'être compté au nombre des hommes; et quiconque ne sait pas se taire est indigne de gouverner (L. iii, p. 39).

${ }^{10}$ Dialogues des Morts, Socrate et Alcibiade. 
Nous regardions avec horreur un roi livré à l'avarice et à la volupté (L. iii, p. 54).

Le roi ne doit rien avoir au-dessus des autres, excepté ce qui est nécessaire, ou pour le soulager dans ses pénibles fonctions, ou pour imprimer aux peuples le respect (L. v, p. 77).

Le plus malheureux de tous les hommes est un roi qui croit être heureux en rendant les autres hommes misérables (L. v, p. 87).

Un roi entièrement tourné à la guerre voudroit toujours la faire: pour étendre sa domination et sa gloire propre, il ruinerait ses peuples (L. v, pp. 88-89).

Un conquérant est un homme que les dieux, irrités contre le genre humain, ont donné à la terre dans leur colère ... (L. vii, p. 146).

Heureux celui qui n'étant point esclave d'autrui, n'a point la folle ambition de faire d'autrui son esclave (L. vii, p. 146).

Mais c'est l'autorité qui met tous les talents à une rude épreuve, et qui découvre de grands défauts (L. x, p. 209).

Un roi, quelque bon et sage qu'il soit, est encore homme. Son esprit a des bornes, et sa vertu en a aussi (L. x, p. 210).

les pays où la domination du souverain est plus absolue sont ceux où les souverains sont moins puissants ... Le roi, qui ne peut être roi tout seul et qui n'est grand que par ses peuples, s'anéantit lui-même peu à peu par l'anéantissement des peuples ... Le mépris, la haine, le ressentiment, la défiance ... toutes les passions se réunissent contre une autorité si odieuse (L. $x$, p. 227).

leur excessive magnificence fondée sur la ruine des peuples... leur cruauté qui cherche chaque jour de nouvelles délices parmi les larmes et le désespoir de tant de malheureux ( $L$. xiv, p. 328).

le travail qui doit être inséparable de la royauté, pour le soulagement des peuples (L. xiv, p. 330). 
les rois qui, au lieu d'être de bons et vigilants pasteurs des peuples, n'avaient songé qu'à ravager le troupeau comme des loups dévorants (L. xiv, p. 331).

Ainsi, les bons rois sont très-rares; et la plupart sont si méchants que... (L. xiv, p. 336).

\section{Laws and Property}

Although the general statements in the Télémaque regarding laws, property, morals, religion, and nature are not so clearly epigrammatic in form as is the case in statements regarding royalty, there are nevertheless a number of ideas on these subjects so clearly and concisely put that they deserve quotation.

Les bons rameurs mêmes ont des récompenses sûres, ... on les nourrit bien; on a soin d'eux quand ils sont malades; en leur absence on a soin de leurs femmes et de leurs enfants; s'ils périssent dans un naufrage, on dédommage leurs familles. C'est ainsi qu'on mène les hommes, sans contrainte... L'autorité seule ne fait jamais bien (L. iii, p. 50).

il ne faut permettre à chaque famille... de pouvoir posséder que l'étendue de terre absolument nécessaire ... Cette règle étant inviolable, les nobles ne pourront point faire des acquisitions sur les pauvres (L. x, p. 225).

Ici on punit trois vices ... : l'ingratitude, la dissimulation et l'avarice (L. v, p. 76).

la liberté du commerce était entière: bien loin de le gêner par des impôts, on promettait une récompense à tous les marchans qui pourraient attirer à Salente le commerce de quelque nouvelle nation ... On punit sévèrement toutes les banqueroutes, parce que celles qui sont exemptes de mauvaise foi ne le sont presque jamais de témerité (L. x, p. 214).

presque tous les hommes ont l'inclination de se marier; il n'y a que la misère qui les en empêche. Si vous ne les chargez 
point d'impóts, ils vivront sans peine avec leurs femmes et leurs enfants (L. $x$, p. 222).

Les princes avides et sans prévoyance ne songent qu'd charger d'impôts ... (L. x, p. 223).

Il y a deux choses pernicieuses, dans le gouvernement des peuples, auxquelles on n'apporte presque jamais aucun remede... La première est une autorité injuste et trop violente dans les rois; la seconde est le luxe, qui corrompt les mœurs (L. xvii, p. 393). N'entreprenez jamais de gêner le commerce pour le tourner selon vos vues. Il faut que le prince ne s'en mêle point, de peur de le gêner, et qu'il en laisse tout le profit à ses sujets qui en ont la peine (L. iii, p. 48).

\section{War}

Fénelon's hatred of war appears not only in the absence of war in la Bétique, and in Mentor's success in keeping Idoménée from engaging in wars, but also in many expressions of sentiment against war in general. Sentiments unfavorable to kings of the conqueror type have already been cited. General sentiments against war are found throughout the Telemaque. That these are reflections of Fénelon's reading of the Ancients does not decrease their force in 1699. Some few are:

Il faut être toujours prêt à faire la guerre, pour n'être jamais réduit au malheur de la faire (L. x, p. 221).

le vrai moyen d'eloigner la guerre et de conserver une longue paix, c'est de cultiver les armes ... c'est d'être également incapable et de faire la guerre par ambition, et de la craindre par mollesse (L. xi, pp. 262-263). .

En rentrant dans le camp, ils virent ce que la guerre a de plus lamentable: les malades et les blessés ... poussant vers le ciel d'une voix plaintive et mourante des cris douloureux ... voila les maux que la guerre entraine après elle!... Les malheureux mortels! ils ont si peu de jours à vivre sur la terre! ces jours 
sont si misérables! pourquoi précipiter une mort déjà si prochaine! (L. xiii, p. 304).

Les lions ne font point la guerre aux lions... ils n'attaquent que les animaux d'espèce différente: l'homme seul, malgré sa raison, fait ce que les animaux sans raison ne firent jamais ... Combien y a-t-il de terres désertes! le genre humain ne saurait les remplir. Quoi donc! une fausse gloire, un vain titre de conquérant, qu'un prince veut acquérir, allume la guerre dans des pays immenses! (L. xiii, p. 305).

\section{Cosmopolitanism}

If pity for the suffering of the poor, the sick, and the wounded has a flavor of sensibilité, the cosmopolitanism of the Télémaque is even more definitely a symptom of the great cosmopolitanism of the 18th - century. The election of a king in Crete (L. v) has a certain similarity to the internationalism of the Olympic Games. Men of many lands compete in the athletic and mental competitions. Cosmopolitanism is urged, however, not only as a benefit in one country but as a policy among states.

Recevez bien et facilement tous les étrangers; faites-leur trouver dans vos ports la sûreté, la commodité, la liberté entière (L. iii, p. 47).

Les peuples y accoururent bientôt en foule de toutes parts ... chacun... vivait, paisible et en sûreté, dans Salente comme dans sa patrie (L. x, p. 215).

Nous avons attiré dans ce pays beaucoup de peuples étrangers (L. xvii, p. 393). ${ }^{11}$

Pour les alliés, quand ils sont prêts à se faire la guerre les uns aux autres, c'est à vous à vous rendre médiateur. Par là vous acquérez une gloire plus solide ... que celle des conquérants;

I1 The similarity to reports of kind reception of strangers in East Indian trade centers will be noted. (See Chapter III, Les Voyages du Sieur Vincent Le Blanc.) 
vous gagnez l'amour et l'estime des étrangers; ils ont tous besoin de vous: vous regnez sur eux par la confiance ... En cet état, qu'un peuple voisin vous attaque ... il vous trouve aimé et secouru (L. xi, p. 262).

\section{Education and morals}

The reforming of an entire people, by collective education in Salente has already been mentioned. In this city (L. x, p. 226 and L. xi, p. 259) there are public schools where children are reared according to les lois de Minos pour l'éducation des enfants.

Luxury and extravagance are condemned throughout the book. In fact it is impossible to read much in the Télemaque without finding repeated condemnations of these vices. To cite particular cases seems needless.

Wine is characterized as la source des plus grands maux parmi les peuples (L. x, p. 226). The virtuous inhabitants of la Bétique not only craignent le vin comme le corrupteur des hommes (L. vii, p. 147) but have a single code of morals for men and for women:

L'honneur des hommes, en ce pays, dépend autant de leur fidelité à l'égard de leurs femmes, que l'honneur des femmes dépend, chez les autres peuples, de leur fidelité pour leurs maris (L. vii, p. 147).

\section{Religion}

Although the exterior religion mentioned in the Télemaque is that of the ancient Greeks, there is little notice given it. Mentor (really Minerva) acts as a guide not only to Télémaque but to others in need of counsel. M. Lanson has called attention to the fact that Mentor is much more like Reason than like any Greek goddess. ${ }^{12}$ It has been noticed that the virtuous people of la Betique

12 Formation de l'esprit philosophique, Revue C. C., 1909, p. 214 (8 avril, 1909). 
have maintained superhuman righteousness by the study of nature. External religion is conspicuously absent in the reforms effected in Salente. A general statement (L. xii, p. 281) is indefinite enough not to conflict with more Deistic utterances elsewhere in the book:

Surtout, ô Grecs, aimez et observez la religion: le reste meurt; elle ne meurt jamais.

The idea of sacrifice, which is a religious and ethical doctrine not found in previous novels of Extraordinary Voyage, is present in the Télémaque, the most striking example being that of King Dioclides (L. xiv, p. 347) who dies to save his people.

If the Télémaque is not a book demonstrating a purely natural religion, ${ }^{13}$ there is in it a disregard of all exterior religion which is striking. There is a remarkable Deistic passage found in Livre iv (p. 71), which goes well with the quiétisme of Fénelon:

il s'entretenait avec Mentor de cette première puissance qui a formé le ciel et la terre; de cette lumière simple, infinie et immuable, qui se donne à tous sans se partager; de cette vérité souveraine et universelle qui éclaire tous les esprits,...

Again, on the following page:

Il n'y a point sur la terre de véritables hommes, excepté ceux qui consultent, qui aiment, qui suivent cette raison éternelle: c'est elle qui nous inspire, quand nous pensons bien; c'est elle qui nous reprend, quand nous pensons mal. Nous ne tenons pas moins d'elle la raison que la vie.

Télémaque says of these opinions of Mentor (L. iv, p. 72):

Quoique je ne comprisse point encore parfaitement la profonde sagesse de ces discours, je ne laissais pas d'y goater je ne sais

${ }^{13} \mathrm{M}$. Lanson has called attention to the opinion of the abbé Nicolas Gédoyn to this effect (Revue des C. et C., 1909, p. 214). 
quoi de pur et de sublime ... la vérité me semblait reluire dans toutes ces paroles.

It is however generally Mentor and not Télémaque who expresses the opinions of Fénelon.

\section{Return to Nature}

The ideal State, la Bétique, has been discussed as a community whose perfection is traceable to a study of Nature. In the practical and reformed state, Salente, the reforms carried out require the return to the land of those who are poor or employed in luxury-trades in the cities.

After both Télémaque and Mentor have refused the crown of Crete (L. v), the latter points out to the inhabitants of the island one of their own number as a fitting person to rule them. This person is Aristodème, a man who has taken part in many wars and who has great wisdom. Having tired of the foibles of corrupt civilization,

Il vit gaîment dans un endroit écarté de l'île, où il cultive son champ de ses propres mains (L. v, p. 97).

Upon being elected king, Aristodème accepts with three conditions: first, that he may resign after two years if he has not improved the State; second, that he may continue to live frugally; third, that his children shall not be honored after his death above their fellow-citizens.

Another case of the wise man living apart from his fellows is that of Philoclès ( $\mathrm{L}$. xi). That Philoclès seems to be a reflection of Fénelon himself, in his post at Cambrai, does not alter the fact that this is still another example of the wise man weary of the ways of cities. 


\section{Conclusion}

The Aventures de Télémaque presents a sort of synthesis of the preceding works of Extraordinary Voyage, of utopian civilizations, and of satire, with the new element of the primitive state of nature taken as a sort of prerequisite of virtue. Not only is it the thesis of this book that a virtuous people must be of necessity a simple people, but it is also contended that by taking a people used to living in luxury in a city, it is possible to reform them and bring them happiness and contentment by causing them to return to Nature. In this setting forth of a remedy for existing conditions, the Aventures de Télémaque contains the idea (if not the term) "progress." In advocating the return to a more primitive state from which man has been removed by the complexity of urban life, the Aventures de Télémaque is not only a condemnation of society under Louis XIV, but also a vindication of the natural virtue of uncorrupted man, and a suggestion of the path which will lead (thanks to the spirit of progress) to better conditions. 


\section{CONCLUSIONS}

The Extraordinary Voyage is a type of novel developed during the 17th century in French Literature. It may be distinguished from other types of novel, such as pastoral, adventurous, or burlesque, because of its realistic setting in a far-off country and because of its didactic content. It may be distinguished both from philosophic works of the Utopia type and from fantastic imaginary voyages to other planets or to non-existent countries because of its geographic realism.

The Extraordinary Voyage in the 17th century in France is a product of two factors: (1) An interest, particularly after 1650, in newly discovered lands and peoples, as reported in accounts of voyages actually made; (2) A growth of rationalism - the emancipation of reason from dogmatic tradition in thought.

Disregarding works of pure imagination, there is in accounts of real voyages a constant comparison of distant lands with European countries throughout the 17th century. One of the influences not to be overlooked in studying the development of Deism in Europe is that of numerous reports coming to Europe of far distant lands enjoying peace and plenty without churches, without priests, and without the external forms of religion.

Direct and open comparison of conditions in little known lands with conditions in Europe (involving criticism unfavorable to Europe), is found as early as 1648 in accounts of voyages. Pierre Bergeron's version of the Voyages fameux du sieur Vincent Le Blanc contains 
the chief elements of the Extraordinary Voyage: (1) Realistic exotic setting; (2) Presentation of a state of society better than that found in Europe with regard to economic, social, and religious conditions. It is but a step from this elaborated account of a real voyage to the complete novel of Extraordinary Voyage.

In the first complete novel of Extraordinary Voyage known, Foigny's Terre australe connue (1676), the realistic beginning and end of the story are strongly tinged with adventure that is at times fantastic. The device used by the author to solve social and moral problems, - a hermaphroditic colony - is original, but perhaps not as fantastic as would appear to-day when world-old legends of hermaphroditism have been forgotten through the progress of discovery and science. Rationalism and Deism are characteristics of this novel.

There is ample testimony that many believed the Histoire des Sévarambes of Vairasse (1677-1679) to be an account of a voyage actually made. There is no trace of the fantastic in this matter-of-fact novel. It is to be noted that the plausible and convincing first part of the story was published by Vairasse in English (London, 1675), and that it is very carefully authenticated. In the Australian society described, rational rather than traditional ideas favor simplicity, labor on the land, compulsory marriage, and the abolition of classes and inequalities. This society is strictly regulated by elected officials. The doctrines of Deism and of reincarnation of souls are defended. The author scorns the clergy of Europe, and mocks the belief in miracles among Christians. Rimed verse is condemned as puerile.

The Aventures de Télémaque (1699) may not only be considered as the source of a great influence in the 18th century, but may also be taken as the culmination, in the 17 th century, of a tendency to write the defense of 
rationalistic ideas in the form of a novel. The author of the Télemaque was evidently familiar not only with accounts of American Indians but with accounts of cosmopolitan population in various sea-ports.

All novels of Extraordinary Voyage of the 17th century in French literature are influenced by published accounts of real voyages. In the work of Foigny and of Vairasse it is possible to point out the particular indebtedness. In the work of Fénelon, an infinitely greater artist, it is the spirit rather than the details of real voyages that it is possible to trace.

No apology is required for studying the work of Fénelon. The importance of the work of Foigny and Vairasse is limited, but far from being negligible. There is no evidence in the Télémaque that Fénelon knew of the existence of either Foigny's or Vairasse's novel. It is not through their relation to the Télemaque that the two earlier Extraordinary Voyages claim attention. Vairasse, if not Foigny, had followers and imitators in the French novel after 1700 , but imitators only among the mediocre authors. The novels of Foigny and Vairasse have been considered as worthy of notice by recent scholars in studying the history of ideas.

Considering the Terre australe connue and the Histoire des Sévarambes as novels rather than as examples of didactic literature, there is an interesting conclusion to be drawn. Perhaps in some measure because of their unfavorable reception by the orthodox, these books were fairly well known for a few decades after they were published. Through realism borrowed from accounts of actual voyages, they differed markedly from earlier novels. In other words, they formed a distinct type of novel. That they were recognized as constituting such a distinct type would appear from the criticism of at least one reviewer of Robinson Crusoe when this novel appeared 
in 1719. The-London correspondent of the Nouvelles littéraires of Amsterdam, in December 1719, found the then recently published story of Robinson Crusoe to be a novel dans le goût de l'Histoire des Sévarambes et de Jacques Sadeur." 1

It is not contended that Defoe was in any way indebted to either of these novels. Scholars interested primarily in Defoe have searched both the Terre australe connue and the Histoire des Sévarambes from cover to cover without finding anything that could not as well have been imitated from other works. The point is that by Foigny and Vairasse there was created in France a type of philosophic novel in a realistic setting, and that this creation of a type of novel on the part of these men, utterly forgotten in later years, was recognized by at least one critic at the time the Robinson Crusoe was published. That the genius of Defoe, through the novel Robinson Crusoe, had a marked influence in France in the 18th century is not to be contested. That this sort of novel was known in France, however, forty years before the Robinson Crusoe was published, and so known that the story of Defoe was classified easily by some French readers at the time of its appearance, is likewise incontestable.

1 Robinson Crusoe en France, W. E. Mann, Paris, 1916, p. 14. The Nouvelles littéraires has not been available for consultation. The statements made depend upon Dr. Mann's citations in the thesis quoted. 



\section{APPENDIX}

1. The History of the Sevarites.

2. Condemnation of Rimed Verse.

3. Publication of Voyages.

\section{The History of the Sevarites}

There was licensed at London on April 22nd, 1675, the first part of the Histoire des Sévarambes, printed in English, with the following title:

\section{THE HISTORY OF THE SEVARITES OR SEVARAMBI,}

a nation inhabiting a part of the third continent, commonly called

Terrae Australes Incognitae

with an Account of their admirable Government, Religion, Customs, and Language.

Written by one Captain Siden.

Printed for Henry Brome at the Gun at the West End of St. Pauls Church-Yard.

LONDON 1675.

The To the Reader of this first part is practically identical with the $A u$ lecteur of complete French editions of the Histoire des Sévarambes, the same evidence of veracity of the story being adduced. The To the Reader is signed D. V., a definite enough proof of the authorship of Denis Vairasse, if it be considered that "Siden," the name of the supposed author, is an anagram of "Denis," and 
that "Sevarias" the name of the Australian law-giver, is "Vairasse" transposed.

This first part ends when the shipwrecked party, having definitely settled in their exotic colony, and having divided their women and set up their polyandrous schedule, come into contact with the highly civilized natives. Captain Siden does not in this part proceed into the interior, nor does he arrive at the capital founded by Sevarias. All of the account of the landing after shipwreck, the searching for water, the founding of the palisaded camp, the dispatch of the pinnace to Batavia for aid, is identical with the French version.

Part II of the History of the Sevarites has on the title page:

A further Account of their admirable Government, Religion, Customs, and Language.

The Second Part more wonderful and delightful than the First.

\section{LONDON 1679}

The license is of February $167_{9}^{8}$. The book was printed by Roger L'Estrange.

The To the Reader of this second volume is unsigned. If it was written by Vairasse, which seems doubtful, it is certain that it has little resemblance to the corresponding portion of the French editions.

In reading of the battles of Captain Siden with ferocious beasts in this part of the book, one is not reminded of Sadeur and the Urgs but rather of the feats of M. de Crac and Baron Munchausen of the following century - or of the entertaining gabs of the peers of Charlemagne.

The doughty Captain Siden, being bitten in the buttocks by a leopard, turned and (speaking in his own person) 
pulled him by the ears, thrusting one of my fingers into its right Eye. The pain forced him to let go his hold, which as soon as he had done, he leaped upon me with his open Jaws, into which I thrust my right hand and took hold of the Tongue. ... I pluckt it by the root whiles the beast held me with its Paws. At that instant six roaring Lions and three Bears, with an infinite number of Jaccals, had overtaken and surrounded me. I flung amongst them the Leopard's Tongue....

They fight over this fresh meat, and Captain Siden escapes in the confusion. ${ }^{1}$

The chief difference between this Second Part and the corresponding part of the French version is the lack of philosophic and social discussion in the English text. There are many pages of cures by talismans and wonders performed by them. ${ }^{2}$ There is a marvelous spring which purifies men from all passions, and in which the visitors are forced to bathe before entering the country of Sevarinde (the capital and immediate vicinity). ${ }^{3}$ There is also a trace of de Quir's Petition to the King of Spain, possibly taken in this case from the translation of Purchas' Pilgrimes.

They know not what it is to live always in fear, to be poysoned by Asps, Scorpions, Snakes, or to be devoured by flying Serpents and Crocodiles, which in other kingdoms swallow man and beast. ${ }^{4}$

The insistence of Sadeur on this absence of vermin in Australia, and his evident wish to agree with de Quir, has been mentioned in the part of this study devoted to Foigny. That The History of the Sevarites should be influenced by de Quir's Petition in this Second Part and that de Quir's Petition had no influence in the French Histoire des Sévarambes of Vairasse (1677-1679) is in-

1 Part II, p. 26.

2 Part II, pp. 110-119.
3 Part II, p. 11.

4 Part II, p. 37. 
teresting. It would seem extremely likely that this Second Part was written by some other than Vairasse. It is of course possible that Vairasse wrote it before he wrote the French version.

That Vairasse did not write the Second Part of the English version is easier of belief when the lack of philosophical and social material is considered. The Sevarites have private property, riches, influence. The laws and maxims of Sevarias are conspicuously absent, and the story ends in a very trite fashion by the return of all the Europeans to Batavia on a vessel sent to fetch them. Siden and his companion Maurice each have married a Severambian lady. The fact that Siden's bride is the daughter of a rich merchant will suffice to show the difference between this English Second Part and the later part of the French novel, devoted to long diatribes against personal property and its evils. The History of the Sevarites has no social content, and almost no religious content. There is a moral content, but this is chiefly the defense of polygamy and an experimental proof of the iniquity of polyandry found in the first part of the French version.

\section{Condemnation of Rimed Verse}

(Histoire des Sévarambes, 1678-1679)

The following is taken from the first edition of the Histoire des Sévarambes, 2ième Partie, printed at Paris, 1678-1679:

Je voulus une fois dans une compagnie de beaux esprits parler de nos vers rimés et les comparer aux vers métriques, pour voir ce qu'ils en diraient; mais ils traitèrent cela de ridicule et de barbare, disant que les rimes ne faisaient que gesner le bon sens et la raison et qu'elles ne produisaient rien qui pût émouvoir les passions, ni donner de la grâce et du mouvement aux vers. 
En effet je ne trouve rien de plus ridicule que les rimes, quoique de grandes nations, d'ailleurs assez polies, en soient si entestées que d'en faire leurs délices, comme les petits esprits font les leurs des pointes et des équivoques. Il me semble que ces vers rimés font un certain carillon à peu près semblable aux clochettes qu'on pend à la cage ronde d'un écureuil... Car quel est l'homme raisonnable qui voudrait s'y amuser ou l'écouter plus d'une fois?... Car qu'y a-t-il de plus ridicule que de faire parler en rimes, comme on fait dans diverses comédies, une harengère, un savetier, un paysan, un petit enfant et telles autres personnes?

Est-il rien de plus absurde que de vendre, d'acheter, de plaider, de prescher, de boire, de manger, de se battre, de faire son testament et de mourir en rimant? Et ce qui est encore plus ridicule que tout cela, est de vouloir que sur le théâtre, dans un changement de scène, celui qui était absent et qui n'avait nullement ouĩ les dernières paroles qu'on avait dit, avant qu'il arrivast, rime avec le dernier vers qu'on a prononcé, comme s'il l'avait ouĩ et qu'on lui eut donné le temps de chercher une rime pour y répondre. Certainement tout homme de bon sens qui fera réflexion sur ces absurdités ne pourra qu'il n'admire l'aveuglement de mille beaux esprits, qui se laissent entraîner à l'estime sotte et vulgaire que l'on fait des rimes. (t. 3, pp. 344-350.)

\section{Chronologicat List of Voyages}

The following is a list of some publications in French between 1600 and 1660 regarding voyages, exploration, and colonization. The Relations of the Jesuits in Canada (published almost yearly at Paris by Cramoisy toward the middle of the century) have been omitted. Almost all books cited by M. Chinard and by M. Martino have been purposely omitted. Books mentioned by these authors have been included in this list only when some considerable notice of them has been given in the text of the present study. Special effort has been made to discover books dealing with foreign countries printed 
between 1649 and 1660 , in order to show that considerable printing of such books in French was undertaken in the ten years before 1660 . The following is not in any way a complete list, but is, on the contrary, intended to supplement the number of such books cited in previous studies.

1600. Chartier, J. Le nouveau miroir des voiages marins. Antwerp. 8vo.

VEER, Gerard. Vraye description de trois voyages faicts en trois ans (Norway, Tartary and China), Amstẹrdam. in-fol.

1601. NecK, JacoB van. Journal ou comptoir, contenant le vray discours... du voiage faict soubs...l'Amiral Jacques Corneille Necq. Amsterdam, in-fol.

1602. Noort, Outvier van. Description du penible voyage faict entour de l'univers ou globe terrestre, Amsterdam, in-fol.

1603. Pimenta, Niccolo. Coppie d'une lettre du P. Nicolas Pimenta visiteur de la Province de l'Inde Orientale. Paris, in 4 .

1604. Bollo, Diego de Torres. La nouvelle histoire du Perou. Paris, 8vo.

VeEr, Gerard. (Another ed. at Amsterdam of Voyages, 1600.)

Vitre, François Martin de. Description du premier voyage faict aux Indes Orientales par les Français. Paris, in-4.

1605. W ytrliet, Cornille. Histoire universelle des Indes, Douai, in-fol.

1606. G6́mara, Lopez De. Histoire generale des Indes Occidentales. Paris, 8vo.

Mendoza, J. Gonzalez de. Histoire du grand royaume de la Chine. Paris, 8 vo.

1607. Wytruiet, C. (Another ed. at Douai, of Histoire des Indes, 1605.)

1608. Mendoza, J. Gonzalez de. (Another ed. at Paris, Histoire de la Chine, 1606.)

1609. Combes, - Le Sieur de. Coppie d'une lettre envoyée de la Nouvelle France ou Canada par le Sieur de Cóbes, Gentilhomme Poictevi à un sien amy. Lyon, $15 \mathrm{pp.}$ 4to. 
1609. Veer, Gerard. (Another ed. of Voyages. Amsterdam, 1600.)

Neck, JACOB van. (Another ed. at Amsterdam of Journal, 1601.)

LoDewijcks, G. M. A. W. Premier livre de la navigation aux Indes Orientales par les Hollandois. Amsterdam, fol.

1610. Linschoten, Ian H. van. Histoire de la navigation de Jean Hugues de Linscot, Hollandois. Amsterdam, in-4.

Veer, Gerard. (An edition at Paris, in-8, of Voyages, Amsterdam, 1600.)

Noort, Ouivier vav. (Another ed. of Voyages, Amsterdam, 1602.)

1616. Mocquet, Jean. Voyages en Afrique, Asie, Indes Orientales, etc. Paris, 4to.

1617. Mocquet, Jean. (Second ed. at Paris of Voyages, 1616.)

1634. Bergeron, Pierre. Relations des voyages en Tartarie. Paris, in-8, 1634.

1640. Lanet, Joannes De. Histoire du Nouveau Monde ou ... des Indes Occidentales, Leyden, 1640, in-fol.

Botton, JACQCes. Relation de l'establissement des François depuis l'an 1635 en l'isle de la Martinique. Paris, 8vo.

1641. Drake, Sir Francis. Le voyage curieux, faict autour du monde. Paris, 8vo.

1643. Anon. Les veritables motifs de Messieurs et Dames de la Société de Nostre Dame de Monreal pour la conversion des sauvages de la Nouvelle France. (No place.)

1645. C. D. B. S. D. L. G. (See Bibl. "Anon.") Relation d'un voyage aux Indes Paris, in-8.

Mocquet, Jean. (An edition at Rouen, of the Voyages, Paris, 1616.)

1647. La Peyrère, Isanc de. Relation du Groenland. Paris, 8vo.

1648. Le Blanc, Vincent (P. Bergeron, editor). Les Voyages fameux du sieur Vincent Le Blanc. Paris, small 4 to.

1649. Le Blanc, Vincent (P. Bergeron, editor). (Second edition of Voyages fameux of 1648.)

1651. Morisot, Craude B. Relations veritables et curieuses de l'isle de Madagascar et du Bresil ... d'Egypte . . . de . Perse, etc. Paris, 4to.

Marucci, Giovanni. Relation de ce qui s'est passé dans les Indes Orientales. Paris, 8vo.

1652. Dupuis, Mathias. Relation de l'establissement d'une colonie fraņ̧oise dans la Gardeloupe. Caen, in-8. 
1652. Rhodes, Alexandre De. Relation des progrez de la foy au royaume de la Cochinchine. Paris, 8vo.

Sanson, Nicolas (D'AbBeville). L'Asie en plusieurs cartes ... traittés de géographie et d'histoire. Paris, in-fol.

1653. Gouz, François de Laboullaye de. Les Voyages et observations.... en Italie, Grece, Syrie, Palestine, Arabie, Egypte, Irelande, Pologne ... etc. Paris, 4to.

Rhodes, Alexandre de. Divers voyages et missions en la Chine \& d'autres royaumes de l'Orient. Paris, 4 to.

1654. Boym, Michel. Briefve relation de la notable conversion des personnes royales ... en la Chine. Paris, 8vo.

Martini, M. Histoire de la guerre des Tartares contre la Chine (transl. from Latin). Douai, 24mo. in eights.

1656. Pagan, Blaise François (Comte de). Relation historique et géographique de la grande rivière des Amazones dans l'Amérique. Paris, 8 vo.

1657. Sanson, Nicolas (D'Abbeville). L'Amérique en plusieurs cartes \& ... traittés de géographie, et d'histoire. Paris, fol.

Gouz, François de Laboullaye de. (Another ed. of Voyages, 1653.)

Anon. Petit catechisme avec les prières du matin et du soir, que les missionaires font \& enseignent aux néophytes de l'isle de Madagascar... en françois \& en cette langue. Paris, 8vo.

1658. Anon. (Another ed. of Petit catechisme, Paris, 1657, containing also Petit recueil de plusieurs dictions ... quelques mots de la langue des sauvages du Cap de Bonne Esperance, $8 \mathrm{vo}$.)

Brontius, JACOB. Histoire naturelle des Isles Antilles de l'Amérique. Rotterdam, 4to. 


\section{BIBLIOGRAPHY}

\section{Works Consulted in the Present Study, AND Works Relating to the SubJect}

It has been considered advisable to give names of some works (chiefly philosophical and theological) which have not been consulted, simply to facilitate more special studies by others. All such works and editions are marked Not consulted.

Books of travel, exploration, and colonization printed in French between 1600 and 1660 which have been mentioned but not discussed in this study are listed chronologically in the Appendix, and will not be found in this Bibliography.

Catalogues of books in libraries and collections have not been included in this Bibliography.

\section{ANONYMOUS}

Nouvelles de l'Amérique ou le Mercure Amériquain. Rouen, 1678 , in-12.

Relation d'un voyage aux Indes-Orientales par un Gentilhomme François arrivé depuis trois ans, avec une hydrographie pour l'intelligence dudit voyage. Paris, chez Pierre Villery et Jean Guignart, MDCXLV. (Privilège to C. D. B. S. D. L. G.) 1645.

(See also: Leguat, and Paulmier.)

Artus, Thomas (Sieur d'Embry)

Les Hermaphrodites. Paris, 1605, in-12. (Not consulted.)

Les Images ou tableaux de platte peinture des deux Philostrates ... mis en françois par Blaise de Vigenère, avec des epigrammes de T. A. Paris, 1614, in-4. (Not consulted.)

(Later editions of 1615, 1629, 1630, 1637.)

L'histoire de la décadence de l'Empire grec, et establissement de celuy des Turcs ... et des tableaux prophétiques predisans la ruine de la mesme monarchie, par Artus Thomas. Paris, 1620, in-4. (Translation of work by Chalcondylas with additions.) (Not consulted.) 
Artus, Thomas (Sieur d'Embry) - Continued

The same: Avec la continuation de la mesme histoire jusques a l'an 1612, par T. Artus. Paris, 1650, in-4. (Not consulted.) Description de l'isle des hermaphrodites, nouvellement découverte, contenant les Mours, les Coutumes \& les Ordonnances des Habitans de cette Isle, comme aussi le Discours de Jacophile d Limne, avec quelques autres pieces curieuses. Pour servir de supplement au Journal de Henri III. A Cologne, chez les Heritiers de Herman Demen, MDCCXXIV (1724).

Avezac. (See: D'Avezac.)

Bacon, Francis

Nova Atlantis (1627). In Ideal Commonwealths, London (George Routledge and Sons), $18 \mathrm{~s}$.

BARNI, J.

Histoire des idées morales et politiques en France au xviie siècle. Paris, 1865-1867, 2 vols. (In Bibl. d'hist. contemporaine.)

\section{Baudrillart, HeNRI}

Publicistes modernes. Paris, 1863.

Bayle, Pierre

Dictionnaire critique et historique. Rotterdam, 1697 (4 vol. in-fol.). Rotterdam, 1715 (3rd ed., 4 vol. in-fol.).

Beaudoin, Jean

(Translator of Comentarios de los Incas (1617) of Garcilaso. See: Garcilaso.)

Bergeron, Pierre

Traité de la navigation et des voyages de descouvertes. Paris, chez Jean de Heucqueville, 1629. (Not consulted.)

Relation des Voyages en Tartarie, plus un traicté des Tartares, avec un abregé de l'histoire des Sarasins et Mahometans, le tout recueilly par Pierre Bergeron, Parisien, à Paris, chez Michel Soly, MDCXXXIV. Avec privilege du Roy. (1634), in-8.

Les Voyages fameux du sieur Vincent LeBlanc, Marseillois. (Qu'il a faits depuis l'aage de douze ans jusques à soixante, aux quatre parties du monde.) Redigez fidellement sur ses Memoires \& Registres, par Pierre Bergeron, Parisien, à Paris, Chez Gervais Clousier, MDCXLVIII. Avec privilege du Roy. (1648), in-4.

Second edition: Same title. Paris, 1649. Third edition. Troyes, 1658. Transl. English, The World Surveyed. London, 1660.

Bernier, François

Histoire de la dernière révolution ... du royaume du Grand Mogol. Paris, chez Barbin, 1671, 2 vol. 
BibliothèQue. (See: Voyages Imaginaires.)

BotRignon, ANTOINETte. (1616-1680)

Le nouveau ciel et la nouvelle terre. Amsterdam, 1679. (Not consulted.) (Cited by P. Bayle, Dictionnaire, Art. Adam.)

Brosses, Charles de (Le Président)

Histoire des Navigations aux Terres Australes. Paris, 1756,

$(2$ vols. in -4.$)$

Brunet, Jacques-Charles

Manuel du Libraire et de l'amateur de livres. Paris, 1865, (6 vols. in-12.)

Campanelia, Thomas

Civitas Solis (Paris, 1637). In Ideal Commonwealths. London, (George Routledge and Sons), 1893, in-12.

Camos, A. G.

Mémoire sur la collection des Grands et Petits Voyages, et sur la collection des Voyages de Melchisedech Thévenot, A. G. Camus, membre de l'Institut national. Paris, 1802, in-8.

Carpin, Jean do Plan

Relation de Voyage en Tartarie (1246) in Relation des Voyages en Tartarie, etc., of Pierre Bergeron. (See Bergeron.)

Chalcondylas (or Chalcocondylas). (See: Artus.)

Chapelain, Jean

Lettres (ed. Tamizey de Larroque), Paris, 1880-1883, in-4.

Charpentier, François

Défense de la langue française, etc. Paris, 1676, in-12. (Not consulted.)

Chaudon et Delandine

Dictionnaire universel (9 ed.). Paris, 1810, 2 vols. in-4. Chinard, Gilbert

$L^{\prime}$ Exotisme américain dans la littérature française au $\mathrm{XVI}^{\ominus}$ siècle, d'après Rabelais, Ronsard, Montaigne, etc. Paris, 1910 , in-16.

L'Amérique et le rêve exotique dans la littérature française au $\mathrm{XVII}^{\mathrm{e}}$ et au XVIII ${ }^{\mathrm{e}}$ siècle. Paris, 1913, in-16.

Conant, Martha P.

The Oriental Tale in England in the 18th Century. (Thesis, Ph.D., Columbia University.) New York, 1908, $18 \mathrm{~cm}$.

D'Avezac, M. A. P.

Relation authentique du voyage du Capitaine de Gonneville, Paris, 1869, in-8. 
De Bry, Johann Theodore \& Johann Israel

Americae insignis \& admiranda Historia. Francfort, 1590-1630.

(14 Parts, bound as 8 vols. in-4.)

Indiae Orientalis Historia, etc. Francfort, 1598-1628.

Parts, bound as 6 vols. in-4.)

(Often referred to as the Grands et Petits Voyages, or Long and

Short Voyages.)

Defoe, Daniel

The Life and strange surprizing Adventures of Robinson Crusoe

of York, Mariner: etc. Written by himself. Oxford ed, 1910.

Delnove, AbBe $\mathrm{H}$.

Essai critique sur le réalisme Thomiste comparé à l'idéalisme Kantien. (Thèse) Lille, 1907, in-8.

Delvaille, Jules

Essai sur l'histoire de l'idée de progrès jusqu'à la fin du xviiie siècle. Paris, 1910, in-8.

FAYeTte, Mme. De LA

Euvres complètes de Mmes de la Fayette, de Tencin et de Fontaines. Paris, 1825. (Vols. i, ii, and iii), 5 vols. in-8.

Fenelon, (François de Salignac de la Mothe)

Aventures de Télémaque (1699). Ed. Didot Frères. Paris, 1859 , in-12.

G. Lanson. Manuel Bibliographique. Nos. 6698-6702 and 6629.

Foignt, Gabriel

LA TERRE / AUSTRALE / CONNUE: / C'EST A DIRE, / LA DESCRIPTION / de ce pays inconnu jusqu'ici, / de ses mours \& de ses coutumes. / PAR MR. SADEVR, / A vec les avantures qui le conduisirent en / ce Continent, \& les particularitez $d u$ / sejour qu'il $y$ fit durant trente-cing ans / \& plus, $\&$ de son retour. / Reduites \& mises en lumiere par les / soins $\&$ la conduite de G. deF. / A VANNES, / Par Iaqves Vernevil ruë / S. Gilles, 1676. (Small 12mo)

Other editions of above. (Title: Les Avantures de Jacques Sadeur, etc.), chez Barbin, Paris, 1692; chez Barbin, Paris, 1693; chez G. Cavelier, Paris, 1705; chez David Mortier, Amsterdam, 1732.

Les Avantures de Jacques Sadeur, in Bibliothèque des Voyages Imaginaires. Amsterdam, 1787-1789, vol. 24.

English transl. (probably of $1692 \mathrm{ed}$.$) : A$ new discovery of Terra incognita Australis by Mr. Sadeur. London, 1693. 
Foignt, Gabriel - Continued

Usage du Jeu royal de la langue latine. Lyon, 1674. Second edition, Lyon, 1676. (Not consulted.)

Fontenelle, Bernard le Bovier sieur de

Relation de l'ile de Bornéo, in Nouvelles de la République de lettres, Jan. 1686. Amsterdam. (Edited by P. Bayle.)

Euvres. Paris, 1790, 8 vol. in-8.

Franck, Adolphe

Réformateurs et Publicistes de l'Europe. Paris (vol. 1, 1864, vol. 2 , 1881, vol. 3,1893$), 3$ vol. in-8.

Garcinaso de la Vega (El Inca Garcilaso)

Le Commentaire royal ou l'Histoire des Yncas, etc., trad. par Jean Beaudoin. Paris, 1633, 2 vol. in-4. (Not consulted.)

Same title, chez J. F. Bernard. Amsterdam, 1737, 2 vol. in-4. (This is the 7th edition of the French translation cited by M. Chinard in L'Amér. et le rêve exotique, p. 437.)

Gadthier, Leon

Ibn Thofail, sa vie, ses œuvres. Paris, 1909, in-12.

Hayy ben Yadqhân, Roman philosophique d'Ibn Thofail, Texte arabe et traduction. Alger, 1900.

Gillo', Huber r

La Querelle des anciens et des modernes en France. Paris, 1914 in-8.

Gonneville, Capitaine Binot Paulmier de. (See: $D$ 'Avezac, and Paulmier.)

Gossouin, - (Maítre)

L'Image du monde de Maître Gossouin. (Texte du manuscrit de la Bibliothèque Nationale, Fonds Français, no. 574.) Thèse de Doctorat de l'Université de Lausanne. $\mathrm{O}$. $\mathrm{H}$. Prior. Lausanne, 1913, in-8.

Gourmont, REMY DE

La Culture des idées. Paris, 1900, in-12.

Godz, François de Laboullaye de

Les voyages et observations du Sieur de la Boullaye-le-Gouz en ... Italie, Grèce, Syrie, Palestine, ... Indes Orientales ... . Arabie ... Egypte ... Irelande . . . Pologne, etc. Paris, chez G. Clousier, 1653, in-4.

Gracián, Baltasar. (Also known by pseudonym Lorenzo Gracian)

El Criticon (1649), in Obras (Amberes, 1669, vol. 1).

L'homme détrompé, ou le Criticon (trad. par Maunory). Paris, 1696. (1st Part of Criticon only) 1 vol. in-12. (Not consulted.) 
Gracián, Baltasar - Continued

The Critick, written originally in Spanish; by Lorenzo Gracian, one of the Best Wits of Spain, and Translated into English, by Paul Rycaut Esq.; London, 1681, in-8.

Günther, Max

Entstehungsgeschichte von Defoe's "Robinson Crúsoe." (Thesis for Ph.D.) Greifswald, 1909, in-8.

HAAG, Eugìne and EMILE

La France Protestante, ou Vies des Protestants français. Paris, $1849-1860,10$ vol. in-8.

Hakluyt, Richard

The Principal Navigations. London, 1598. (Reprints. Glasgow, 1903-1905, 3 vols., $17 \mathrm{~cm}$.)

Huet, Pierre Daniel

Demonstratio evangelica. Paris, 1679, in-fol.

(Revue of this work in Journal des Sçavans, Jan. 9, 1679.)

IMAGE DU MONDE. (See: Gossouin.)

JANet, Paul

Histoire de la science politique: (4th ed.) Paris, 1913, 2 vols. $23 \mathrm{~cm}$.

Jodan, Henri

Un Voyageur français au xvii siècle. (In Mémoires de la Socitté Nationale Académique de Cherbourg, 1904, pp. 1-29.) (Relating to Jean Mocquet, Voyages, 1616.)

JodRnAL DES Sģavans

Years 1675-1683. (1 vol. each year. Small 12mo.) JUstel, $\mathrm{P}$.

Recueil de divers Voyages faits en Afrique et en l'Amérique qui n'ont point esté encore publiez. Paris, chez Louis Billaine, MDCLXXIV. (1674), in-4.

KöRTing, H.

Geschichte des französische romans im 17 Jahrhundert. Oppeln, 1891,2 vol. in-8.

LALEMANT, JeRome

Relation de ce qui s'est passé de plus remarquable aux Missions des Pères de la Compagnie de Jesus en la Nouvelle France és années $1662 \& 1663$. Chez Cramoisy. Paris, 1664, in-12.

Ianson, Gustave

Histoire de la littérature française. (12 ed.) Paris, 1912.

Manuel bibliographique de la littérature française moderne. Paris, 1914. (Nouvelle édition), 4 vol. in-8.

Origines et premières manifestations de l'esprit philosophi- 
Lanson, Gustave - Continued

que, etc. Revue des Cours et Conférences, Dec. 1907-Dec. 1909.

Le rôle de l'expérience dans la formation de la philosophie du xviiie $^{\mathrm{e}}$ siècle en France. Revue du Mois, t. ix (1910).

Le Blanc, Vincent. (See: Bergeron.)

Le Breton, André

Le Roman au xviii ${ }^{\mathrm{e}}$ siècle. Paris, 1898, in-16.

Le Franc, Abel

Les navigations de Pantagruel; étude sur la géographie rabelaisienne. Paris, 1904, in-8.

Leguat, François

Voyages et avantures de François Leguat et de ses compagnons en deux Isles désertes des Indes Orientales, etc. Préface par

Max Misson. London, 1708, 2 vol. in-12.

(Reprinted on same type. London, 1721.)

A new voyage to the East Indies by Francis Leguat, etc. London, 1708. (Not consulted.)

Le Strange, G. (See: Mustaufi.)

Lichtenberger, ANDRÉ

Le Socialisme au xviiie siècle. Paris, 1895.

Le Socialisme utopique. Paris, 1898.

LYSER, JOHANN

Discursus de polygamia, 1673. (Not consulted.)

Polygamia triumphatrix, 1676. (Not consulted.)

ManN, W. W.

Robinson Crusoé en France. (Thèse de Doctorat de l'Université.) Paris, 1916, in-8.

Marchand, Prosper

Dietionnaire historique. The Hague, 1758-1759. 2 vol. in-fol. Marco Polo. (See: Polo.)

Martino, Pierre

L'Orient dans la littérature française au xviie et au xviii ${ }^{\mathrm{e}}$ siècle. Paris, 1906, in-8.

Menendez y Pelayo, D. Marcelino. (See: Tufä̈l.)

Mocquet, JeAN

Voyages en Afrique, Asie, Indes Orientales \& Occidentales faits par Jean Mocquet, Garde du Cabinet des Singularitez du Roy, aux Tuileries. Paris, chez Jean de la Heuqueville, MDCXVII. (Second edition.)

1st ed. (Paris, 1616). (Not consulted.)

Other editions, Rouen, 1645, Rouen, 1665. English translation. London, 1696. 
Molinet, Jean

Recollection des merveilles advenuès de son temps.

(Poem cited by Bayle, Dict. crit. Ed. 1697, p. 988, notes.)

More, Thomas

Utopia (1518). In Ideal Commonwealths (George Routledge and Sons). London, 1893, in-16.

Moreri, Louis

Grand Dictionnaire historique. (Ed. 1732.) Paris, 6 vol. in-fol. Morhof, Daniel Georg

Polyhistor literarius, etc. Lübeck, 1714, in-8.

Morillot, PAUL

Le roman en France de 1610 jusqu'à nos jours. Paris, 1892, in-8.

Mustawfi, Hamd-Allah (of Qazwin)

The Geographical Part of the Nuzhat-Al-Qulub, composed by Hamd-Allah Mustawfi of Qazwin in 740 (1340). Translated by G. Le Strange, Luzac \& Co. London, 1919, in-8.

(This work has more than a slight resemblance to the Images $d u$ Monde found in a corresponding period of French literature.)

Niceron, Jean Pierre

Mémoires pour servir à l'histoire des hommes illustres dans la République des Lettres. Paris, 1724-1745, 43 vol. in-12.

Patot. (See: Tyssot de Patot.)

Paulmier, AbBe. (Also called Abbé Paulmier de Gonneville.)

Mémoires touchant l'établissement d'une mission chrestienne dans le troisième monde autrement appelé la Terre Australe, Méridionale, Antartique, et inconnuë. Dediez à Nostre S. Père le Pape Alexandre VII. Par un Ecclesiastique Originaire de cette mesme terre. Chez Gabriel Cramoisy. Paris, 1663, in-12.

(Name of author: Abbé Paulmier de Gonneville, chanoine de Lisieux, appeared on title page from Jan. 1664.) (Not consulted.)

Pelsart, François (Capitaine)

La Terre Australe descouverte par le Capitaine Pelsart, qui y fait naufrage. (In Relations de divers voyages curieux, etc. of Melchisedec Thévenot, t. 1, Premiere Partie. Paris, 1663.

Poll, Max

The Sources of Gulliver's Travels. (University of Cincinnati Bulletin, No. 24, Series II, vol. III.) November, 1909. 
Polo, Marco

Le livre de Marco Polo rédigé en Français par Rusticien de Pise, publié d'après trois manuscrits inédits par G. Pauthier, Paris, 1865, in-8.

Le livre; fac-similie d'un manuscrit du xiv siècle. Stockholm, 1882 , in-fol.

Prior, O. H. (See: Gossouin.)

Pufendorf, Samuel von

De jure naturae et gentium. London, 1672, in-4. (Not consulted).

Purchas, Samuel

Purchas, His Pilgrimes. London, 1625.

(Reprint, Glasgow, 1906, 20 vol. in-8.)

Quir (or Queiros), Fernando de

8th Petition to King of Spain.

(Contained in De Bry, India Orientalis. Francfort, 1613, Pars $\mathrm{X}$, pp. 13-18. Contained in Purchas, His Pilgrimes. Glasgow, 1906, vol. xvii, pp. 218-246. (English and Spanish text.) Published separately in French. Paris, 1617. (Title: Copie de la requeste présentée au Roy d'Espagne, etc., in-12.) (French version not consulted.)

Rabelais, François

Pantagruel. (CEurres, ed. Louis Moland, Garnier Frères. Paris, 1912.)

Remosat, Charles de

Bacon, sa vie, son temps, sa philosophie et son influence jusqu'à nos jours. Paris, 1877, in-16.

Rigault, H.

Histoire de la querelle des anciens et des modernes. Paris, 1856, in-8.

RUge, Sophus

Entdeckungsgeschichte der neuen Welt. (In Hamburgische Festschrift zur Erinnerung an die Entdeckung Amerika's, Band I. Hamburg, 1892, in-4.)

Saint-Evremond, Charles de

Euvres mêlées. (Ed. Techener Fils.) Paris, 1865.

Segrais, Jean DE

Euvres. Amsterdam, 1723, 2 vol. in-12.

Euvres. Paris, 1755, 2 vol. in-12.

SEILLIÈre, ERnest

Un grand moraliste oublié: Balthasar Gracian. (In: Institut de France. Acad. d. sci. mor. et polit. Séances et travaux, n. s. v. 73 , pp. $474-492$. 


\section{Swirt, Johnathan}

Works, with notes and a life of the author by Sir Walter Scott,

Bart. Edinburgh, 1824, 19 vol. in-12.

Tavernier, Jean Baptiste

Nouvelle relation du sérail du Grand Seigneur. Paris, 1675, in-4.

Les six voyages de J. B. Tavernier. Paris, 1676, 3 vol. in-4.

(2nd ed., 1681.)

Suite des voyages de $\mathrm{Mr}$. Tavernier, ou Nouveau recüeil de plusieurs relations et traitez singuliers et curieux. Paris, 1680. Thevenot, Melchisedec

Relations de divers voyages curieux, qui n'ont pas esté publiées. Par les soins de Melchisedec Thevenot. Paris, 1663-1672, infol.

(2nd ed. chez Thomas Motte. Paris, 1696.)

Thofaĭl, IBN. (Śee: Tufä̈l.)

Thomas, Artus. (See: Artus.)

Thomas, Saint - Aquinas

Opera Omnia. Rome, 1888-1906, 3 vol. in-fol.

TuFä̈L, IBN

Hayy ben Yaqdhan (circa 1160).

Latin transl. by Pocock. Oxford, 1671. (Not consulted.)

English transl. from Latin. London, 1686, 1703, and 1731.

(The improvement of human reason, exhibited in the life of Hai Ebn Jokdhan.) (Not consulted.)

German transl. from Latin. Der von sich selbst gelehrte Weltweise. Frankfurt, 1726. (Not consulted.)

2nd French transl. from MS found at Algiers, by M. Léon Gauthier. (See: Gauthier.)

Spanish transl. from MS. El filósofo autodidacto de Abentofail. (With prologue by Menéndez y Pelayo.) Zaragoza, 1900,

Trssot de Patot, Simon

Voyages et avantures de Jacques Massé. Bordeaux, chez Jacques l'A veugle, 1710, in-12.

Vatrasse, Denis. (Also known as d'Alais, Allais, Veirasse d'Alais.) The History of the Sevarites or Sevarambi, a nation inhabiting a part of the third continent, commonly called Terrae Australes Incognitae. With an account of their admirable Government, Religion, Customs and Language. Written by one Captain Siden. Printed for Henry Brome at the Gun at the West End of St. Pauls Church-Yard. London, 1675, in-12. (1st Part only. 2nd Part, probably not by Vairasse, printed at London, 1679. Same title.) 
Histoire des Sévarambes, peuples qui habitent une partie du troisième continent ordinairement appelé Terre Australe, contenant un compte exact du gouvernement, des mœurs, de la religion et du langage de cette nation, jusques aujourd'hui inconnue aux peuples de l'Europe. Trad. de l'anglois. Partie I. Paris, 1677 (2 vol. in-12). Partie II. Paris, 1678-1679 (3 vol. in-12.)

Histoire des Sévarambes, etc. Brussels, 1682 (5 vol. in-12), Amsterdam, 1682 (5 vol. in-12), 1702 (2 vol. in-12), 1716 (2 vol. in-12), 1787 (In Bibliothèque des Voyages Imaginaires, t. 5).

Translated into Dutch (Amsterdam, 1683), German (Sulzbach, 1689; Nürnberg, without date; Nürnberg, 1714) and Italian (Venice, 1728). (Translations not consulted.)

Histoire des Sévarambes (same titlc as 1677 edition, with addition: Nouvelle Edition, reveue \& corrigée, à Amsterdam, aux dépens d'Etienne Roger, Marchand Libraire, MDCCII). It is this edition that is cited in this study, 5 parts in-12. Bound as 2 volumes. Pages numbered for 2 volumes. (Citations for vol. 1 will be found to correspond also to pages in 1716 ed. Amsterdam, chez Roger. There are thirteen more pages in the 2 nd vol., ed. 1702 , than in the $1716 \mathrm{ed}$.)

Grammaire méthodique, contenant les principes de cet art et les règles les plus nécessaires de la langue françoise dans un ordre clair et naturel. Paris, 1681, in-12. (Not consulted.)

A short and methodical introduction to the French tongue. Paris, 1683, in-12. (Not consulted.)

Vigenìre, Blaise de. (See: Artus.)

Vossius, G. J.

De vera aetate mundi. The Hague, 1659, in-4. (Not consulted.)

Votages Imatinaires (BIBloth ÈQde des)

36 vols. in-8. Amsterdam, 1787-1789.

WACKWITZ, FrIEDRICH

Entstehungsgeschichte von D. Defoe's Robinson Crusoe.

Berlin, 1909 in-8. (Thesis for Ph.D.)

Wrtfliet, Cornille

Histoire universelle des Indes Orientales et Occidentales. A Douay, aux despens de François Fabri, 1605, in-fol. 



\title{
INDEX TO NAMES OF PERSONS
}

\author{
(References are to pages)
}

Acosta, J., 8, 10

Amyot, 126

Aquinas, St. Thomas, $103 \mathrm{n}$, $129 \mathrm{n}$

Ariosto, $50 \mathrm{n}$

Artus, Thomas, 13, 14, 151

Bacon, F., 11, 18, 19, 51 n, 93, $100,101,112,129,148,150$

Baldensperger, F., vi

Basnage, 140

Boyle, P., 37 n, 38, 50 n, 57 $58 \mathrm{n}, 60 \mathrm{n}, 62 \mathrm{n}, 63 \mathrm{n}, 74,75$ 88,140

Beaudoin, J., 67, 115 n

Beaurieu, G. de, xii

Bergerac, C. de S., ix, xi, 128

Bergeron, P., 25, 26, 29, 30, $57 \mathrm{n}$, $66,67,72,108,109 \mathrm{n}, 113 \mathrm{n}$, 116, $118 \mathrm{n}, 120 \mathrm{n}, 121 \mathrm{n}, 162$ (see: Le Blanc)

Bernardin de Saint-Pierre, J. H., 105

Bernier, J., 130 n

Boileau-Despréaux, N., 68

Bossuet, J. B., xii

Bourgogne, duc de, 144 n, 147

Bourignon, Antoinette, 62

Bouton, J., 7

Boym, M., 10

Brendan, Saint, 12, 16
Brosses, C. de, 22 n

Brunet, J. $26 \mathrm{n}$ ?

Bry (see: De Bry)

Campanella, T., 11, 18, 52, $53 \mathrm{n}$, $101,103 \mathrm{n}, 105 \mathrm{n}, 112,129 \mathrm{n}$, 148,150

Camus, A. G., 2 n

Carpin, P., 57, 108

Carrel de Sainte-Garde, 11

Catherine, Saint, 12

C. D. B. S. D. L. G., 6

Chalcocondylas, $14 \mathrm{n}$

Chapelain, J., 11

Charlemagne, 12

Charpentier, F., 133 n

Chateaubriand, F. R. de, xii, 150

Chaudon, L. M., 37 n

Chinard, G., x, xi, 3, 4 n, 5, $10 \mathrm{n}$, $13 \mathrm{n}, 24 \mathrm{n}, 26 \mathrm{n}, 28,30,39$, $52 \mathrm{n}, 59 \mathrm{n}, 61 \mathrm{n}, 82 \mathrm{n}, 92 \mathrm{n}$, $105,118,125 \mathrm{n}, 135 \mathrm{n}, 146,149$

Colbert, J. B., 152

Columbus, C., 93

Conant, M. P., 141 n

Courbeville, P. P. de, 142 n

Cramoisy, G. \& S., 7, 22

D'Avezac, M., 22 n

De Bry, J. \& T., 1, 2, 3, 4, 23, 49, $50 \mathrm{n}, 57,76,77,85$ 
Defoe, D., xii, 96, 105, 142, 165

Delandine (see: Chaudon)

Delon, 89

Delvaille, M., 122 n, 152 n

Desmarets de Saint-Sorlin, J., 133

Devese, 89

Dulaurens, Abbé, xii

Dupuis, M., 7

Du Ryer, P., 130 n

Du Tertre, P., 3

Du Verdier, A., 58

Fayette, Mme. de la, xii

Fénelon, F. de S., xii, 144-161, 164

Foigny, G., xii, 33, 34 n, 35, $36-86,101,104,105,106$, $114,122,128,132,145,146$, $149,163,164,165$

Fontenelle, B. le B. de, xi, 140, 151

Garcilaso (El Inca), 19, 20, 21, $114,115 \mathrm{n}, 117,118,127,150$

Gauthier, M., 141

Gédoyn, N., 159 n

Gomberville, M. L. de, 35, 52

Gonneville (see: Paulmier)

Gossouin (Maitre), 1 n, 54 n

Gourmont, R. de, 129 n

Gouz, F. de L. de, 9

Gracián, B., 140, 141, 142 n, 142

Günther, M., 38 n, 39, 79 n

Haag, E. \& E., 89

Hackluyt, 23, 26

Henri III, 14

Horace, 58

Houdar (see: Mo'te)

Huet, P. D., 73 n

Huxley, T. H., 105
Jouan, H., 4

Justel, P., 5

Kipling, R., 58

Laboullaye (see: Gouz)

Laet, J., 8

Lallemant, J., 7

Lancaster, H. C., vi

Lanson, G., v, ix, x n, xi n, 67 n, $73 \mathrm{n}, 74,99 \mathrm{n}, 119 \mathrm{n}, 126 \mathrm{n}$, $133 \mathrm{n}, 141,144 \mathrm{n}, 152 \mathrm{n}, 158$, $159 \mathrm{n}$

La Rochefoucauld, F. de, 153

Le Blanc, V., 8, 9, 25-34, 48, $57,58,60 \mathrm{n}, 61 \mathrm{n}, 67,119 \mathrm{n}$, $157 \mathrm{n}$

Le Braz, A., vi

Le Breton, A., 146

Leguat, F., 105, 119, 142 n

Le Jeune, P., 7 .

Le Mercier, F., 7

Le Strange, G., 57

L'Hermite, J., 23

Lichtenberger, A., x, xi, xii n, $89,92 \mathrm{n}, 135 \mathrm{n}$

Linguet, S. N. H., xii

Loaisa, G. de, 23

Lodewijcks, G. M., 8

Lyser, J., 119 n

Magellan, F. de, 23, 40

Mann, W. E., 165 n

Marchand, P., 88, 89, 90, 91, 108, 118

Martini, M., 10

Martino, P., 2 n, 10, 118 n

Marucci, G., 9

Menéndez y Pelayo, M., 142

Mocquet, J., 4, 5, 10, 33 n, 34, $119 \mathrm{n}$ 
Molinet, J., 59

More, T., 11, 13, 15, 19, 49, 54 n $93,129,148,150$

Moreri, L., 90 n

Morhof, J., 88, 92

Morisot, C. B., 9

Motte, Houdar de la, A., 133

Mustawf, Hamd-Allah, 56

Patot (see: Tyssot)

Paulmier, B. (de Gonneville), $22 \mathrm{n}, 23,40,52 \mathrm{n}, 79 \mathrm{n}, 93 \mathrm{n}$ Pelleprat, P., 7

Pelsart, F., 23, 95, 96, 98, 99, 106, 138

Pigafetta, P., 50

Pizarro, F., 24, 117

Plato, 11, 19, 57, 74, 85, 93, 101, 129

Plutarch, 19

Polo, M., 2, 22, 26, 29, 109, $113 \mathrm{n}, 115,118$

Pontac, Mme. de, 34

Prior, O. H., 54 n

Pufendorf, S., 126 n

Purchas, 23, 26, 78 n

Quir (or Queiros), P. F., de, 23 n $41 \mathrm{n}, 55 \mathrm{n}, 76,77,78,79,85$

Rabelais, F., 13

Racine, J., xii

Ragueneau, P., 7

Rétif de la Bretonne, xii

Rhodes, A., 9, 10

Rousseau, J. J., xii, 3, 105, 106, $122 \mathrm{n}$

Ruge, S., $79 \mathrm{n}$

Saavedra, F., 23

Sadeur: (see Foigny)
Saint-Evremond, C. de, 68

Sanson, N. (d'Abbeville), 9

Schouten, W., 23

Scudéry, M., 35

Segrais, J., de, 34, 35, 45 n

Seillière, E., 142 n

Siden (anagram of "Denis." See: Vairasse)

Sidney, 89

Simon, R., 130 n

Spencer, H., 105

Spiers, A. G. H., vi

Spinoza, B. 68

Tasman, A., 23

Tavernier, J. B., $113 \mathrm{n}, 118 \mathrm{n}$, $119 \mathrm{n}$

Thévenot, M., 23, 95 n, 99 n

Thofaill (see: Tufaül)

Thomas (see: Artus)

Tiphaigne de la Roche, xii

Todd, H. A., vi

Torres, D. B. de, 8

Torres, P. de, 41, 78

Tufaill, I., 140, 141 n, 142

Tyssot de Patot, S., 119, 126 n

Vairasse, D., xii, 33, 35, 39, 49, $63,87-139,145,146,163$, 164,165

Vauban, S. le P. de, 152

Vimont, B., 7

Vitré, F. M. de, 8, 10

Voltaire, xii

Vossius, G. J., 73 n

Vossius, I., 89

Wackwitz, F., 21 n, 39

Weeks, R., vi

Wytfliet, C., 3 



\section{COLUMBIA UNIVERSITY PRESS}

Columbia University in the City of New York

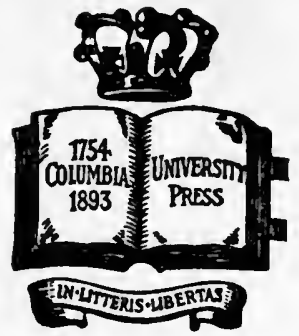

The Press was incorporated June 8,1893 , to promote the publication of the results of original research. It is a private corporation, related directly to Columbia University by the provisions that its Trustees shall be officers of the University and that the President of Columbia University shall be President of the Press.

The publications of the Columbia University Press include works on Biography, History, Economics, Education, Philosophy, Linguistics, and Literature, and the following series:

Columbia University Contributions to Anthropology.

Columbia University Biological Series.

Columbia University Studies in Cancer and Allied Subjects.

Columbia University Studies in Classical Philology.

Columbia University Studies in Comparative Literature.

Columbia University Studies in English.

Columbia University Geological Series.

Columbia University Germanic Studies.

Columbia University Indo-Iranian Series.

Columbia University Contributions to Oriental History and Philology.

Columbia University Oriental Studies.

Columbia University Studies in Romance Philology and Literature.

Records of Civilization: Sources and Studies.

Adams Lectures.

Carpentier Lectures.

Julius Beer Lectures.

Blumenthal Lectures.

Hewitt Lectures.

Jesup Lectures.

Catalogues will be sent free on application.

LEMCKE \& BUECHNER, Agents 30-32 East 2oth St., NEW YORK 


\title{
COLUMBIA UNIVERSITY STUDIES IN ROMANCE PHILOLOGY AND LITERATURE
}

\author{
Ebited by Adolphe Cohn and Henry Alfred Todd
}

FREDERIC MISTRAL, POET AND LEADER IN PROVENCE. By

Charles Alfred Downer, Ph.D. 12mo, cloth, pp. $x+267$. Price $\$ 2.00$ net.

CORNEILLE AND THE SPANISH DRAMA. By J. D. Segall, Ph.D.

12mo, cloth, pp. ix + 147. Price, $\$ 1.75$ net.

DANTE AND THE ANIMAL KINGDOM. By Richard Thayer Holbrook, Ph.D. 12 mo, cloth,pp. xviii +376 . Illustrated. Price, $\$ 2.50$ net.

THE INDEBTEDNESS OF CHAUCER'S TROILUS AND CRISEYDE TO GUIDO DELLE COLONNE'S HISTORIA TROJANA. By George L. Hamilton, A.M. 12mo, cloth, pp. vi+159. Price, $\$ 1.50$ net.

THE ANGLO-NORMAN DIALECT. A Manual of its Phonology and Morphology, with illustrative specimens of the literature. By Louis Emil Menger, Ph.D. 8vo, cloth, pp. $x x+167$. Price, $\$ 1.75$ net.

CORNEILLE AND RACINE IN ENGLAND. A study of the English Translations of the Corneilles and Racine, with special reference to their representation on the English stage. By Dorothea Frances Canfield, Ph.D. 12mo, cloth, pp. xiii +295 . Price, $\$ 2.00$ net.

THE VERSIFICATION OF THE CUADERNA VIA, as found in Berceo's Vida de Santo Domingo de Silos. By John Driscoll Fitz-Gerald, Ph.D. 8 vo, pp. xiii + 112. Facsimiles. Price, paper, \$1.25 net; cloth, $\$ 1.50$ net.

PIERRE LE TOURNEUR. By Mary Gertrude Cushing, Ph.D. 12mo, cloth, pp. $x i+317$. Price, $\$ 2.00$ net.

THE DEVELOPMENT OF STAGE DECORATION IN FRANCE IN THE MIDDLE AGES. By Donald Clive Stuart, Ph.D. 12mo, cloth, pp. ix + 230. Price, $\$ 1.75$ net.

Charles DE SAINTE-MARTHE. By Caroline Ruutz-Rees, Ph.D. $12 \mathrm{mo}$, cloth, pp. xvi +664 . Price, $\$ 2.25$ net.

THE SYMBOLISM OF VOLTAIRE'S NOVELS, with special reference to Zadig. By William Raleigh Price, Ph.D. 12mo, cloth, pp. vi +269. Price, $\$ 1.75$ net.

\section{COLUMBIA UNIVERSITY PRESS}

Lemcke \& Buechner, Agents 30-32 East 20th Street New York 


\section{COLUMBIA UNIVERSITY STUDIES IN ROMANCE PHILOLOGY AND LITERATURE}

Edited by Adolphe Cohn and Henry Alfred Todd

PARTICIPIAL SUBSTANTIVES OF THE -ATA TYPE IN THE ROMANCE LANGUAGES, with special reference to French. By Luther Herbert Alexander, Ph.D. 8vo. pp. xii +163 . Price, paper, $\$ 1.50$ net; cloth, $\$ 1.75$ net.

UNCLE AND NEPHEW IN THE OLD FRENCH CHANSONS DE GESTE. A Study in the Survival of Matriarchy. By William

Ortver Farnsworth, Ph.D. 8vo, cloth, pp. xii +267 . Price, $\$ 2.00$ net.

DIDEROT AS A DISCIPLE OF ENGLISH THOUGHT. By R. LOTALTY CRo, Ph.D. 12mo, cloth, pp. xiii +498 . Price, $\$ 2.25$ net.

LI ROMANS DOU LIS. By Frederick C. Ostrander, Ph.D. In Memoriam. 8vo, cloth, pp. vii +154 . Price, $\$ 1.75$ net.

EUROPEAN CHARACTERS IN FRENCH DRAMA OF THE EIGHTEENTH CENTURY. By HARRY KURz, Ph.D. 8vo, cloth, pp. xii + 329. Price, $\$ 1.75$ net.

THE USE OF THE INFINITIVE INSTEAD OF A FINITE VERB IN

FRENCH. By Benjamin F. Luker, Ph.D. 12mo, cloth, pp. ix + 114 . Price, $\$ 1.50$ net.

THE GLORIA D'AMOR OF FRA ROCABERTI. Edited by H. C. HeAton, Ph.D. 8vo, cloth, pp. xiii +167 . Price, $\$ 1.75$ net.

FRENCH CRITICISM OF AMERICAN LITERATURE BEFORE 1850. By Harold Elmer Mantz, Ph.D. 12mo, cloth, pp. ix + 165. Pricc, \$1.75 net.

THE SPIRIT OF PROTEST IN OLD FRENCH LITERATURE. BY MARY M. Wood, Ph.D. 8vo, cloth, pp. xii +201 . Price, $\$ 1.75$ net.

THE INFLUENCE OF ITALY ON THE LITERARY CAREER OF alphonse DE lamartine. By Agide Pirazzini, Ph.D. 12mo, cloth, pp. xii + 168. Price, $\$ 1.75$ net.

TIRANT LO BLANCH. A Study of its Authorship, Principal Sources and Historical Setting. By Joseph A. VAetr, Ph.D. 8vo, cloth, pp. xvi +169 . Price, $\$ 2.00$ net.

FRENCH TERMINOLOGIES IN THE MAKING. By HaRvet J. Swan,; Ph.D. 8vo, cloth, pp. xxii +250 . Price, \$2.25 net.

COLUMBIA UNIVERSITY PRESS

Lemcke \& Buechner, Agents 30-32 East 20th St., New York 




\section{THE LIBRARY UNIVERSITY OF CALIFORNIA}

Santa Barbara

\section{STACK COLLECTION}

THIS BOOK IS DUE ON THE LAST DATE ST BELOW. 


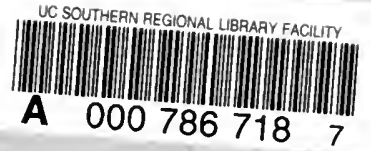

SOUTHersity of California 405 Hilgard AvenugIONAL LIBRARY FACILITY Return this material to th, CA 90024-1388 from which lit was borrowed library

QL JAREC'D LD-URE

$$
\text { DEC } 041996
$$


